\title{
Desde el Gobierno Corporativo a la responsabilidad de los administradores (y II)
}

\author{
Ramón Múgica Alcorta \\ Profesor de Derecho Administrativo y de Derecho Mercantil \\ Universidad de Deusto
}

Recibido: 11.06 .2010

Aceptado: 30.06 .2010

\begin{abstract}
Resumen: En esta segunda parte del trabajo analizamos con brevedad el régimen legal español relativo a los deberes generales o fiduciarios (diligencia, fidelidad y lealtad) de los administradores societarios. Completamos dicha aproximación con unas referencias particulares a la legislación del mercado de valores y a la legislación concursal y, teniendo con ello una idea elemental de las normas aplicables, pasamos a estudiar la jurisprudencia del Tribunal Supremo, en vista de los casos concretos sobre los que este ha tenido que pronunciarse en los últimos años, para tratar de descubrir si la doctrina del Alto Tribunal ha acabado por producir unos principios consistentes, esto es, unas pautas de enjuiciamiento dotadas de estabilidad y certeza, o si, por el contrario, los pronunciamientos están presididos por la idea de la oportunidad y las particulares circunstancias del caso (sentenciasveleta); si el cuerpo de doctrina jurisprudencial es receptivo a planteamientos de las cortes más progresistas de otros países; y en función de qué elementos el tribunal gradúa, elevándola o relajándola, la exigencia de responsabilidad de los administradores.
\end{abstract}

Palabras clave: Administradores societarios; interés social; deberes fiduciarios; diligencia, fidelidad, lealtad; conflictos de interés y oportunidad de negocio; responsabilidad; acción social y acción individual de responsabilidad.

Abstract: In this second part of the assignment we briefly analyze the Spanish legal regime relative to corporate directors and officers' general or fiduciary duties (diligence, faithfulness and loyalty). We complete this approximation with some particular references to the stock market legislation and bankruptcy law, and having with it a basic idea of the applicable rules, we advance on the study of the Supreme Court's common law, considering the specific cases on which this one has had to rule over the last few years, in an attempt to disclose if the high court's doctrine has resulted in some consistent principles, to wit, some prosecution lines endowed with stability and certainty, or if contrarily the pronouncements are chaired by the idea of the opportunity and the particular circumstances of the lawsuit (vane-dictum); if the jurisprudential doctrine corps is receptive to other countries' more progressive courts' approaches; and according to which factors does the judicature calibrates, lifting it or loosing it, the directors and officers' demand of citizenship.

Key words: Corporate directors and officers; social pursuit; fiduciary duties; diligence; faithfulness; loyalty; conflicts of interests and business opportunity; liability; socially responsible and individual responsible action. 
Sumario: I. Segunda Parte. Enlace.-II. Naturaleza de la relación administrador-sociedad mercantil.-III. Precisiones adicionales sobre el propósito y el ámbito del estudio.- - IV. Los deberes generales del administrador: diligencia, fidelidad y lealtad.-V. Referencia a la responsabilidad de los administradores.-VI. Supuestos de responsabilidad en la legislación del mercado de valores.-VII. Responsabilidad de los administradores en el procedimiento concursal. La sección de calificación del concurso.-VIII. Análisis de la jurisprudencia reciente relativa a la responsabilidad de los administradores sociales. - IX. Conclusiones.

\section{Segunda Parte. Enlace}

Completamos con este capítulo el estudio que emprendíamos en el número anterior de la Revista ${ }^{1}$ sobre la responsabilidad de los administradores de las compañías mercantiles en el ámbito del Gobierno Corporativo. En aquella ocasión enmarcábamos nuestro análisis con las reglas de Gobierno Corporativo y con la jurisprudencia más progresista de la justicia americana, en concreto de la Corte de Delaware. Planteábamos entonces la necesidad de dar una dimensión o tratamiento global para el régimen de la responsabilidad de los administradores, pues el ámbito del Derecho de sociedades, por la propia materia sobre que recae (el negocio, la empresa) presenta una vocación indiscutible a la internacionalización, que exige respuestas normativas uniformes. La fractura regulatoria, a la postre, daña el principio de unidad económica, que ya se demanda a escala planetaria, y los déficits reguladores constituyen una forma de dumping que puede producir efectos perversos sobre la inversión ${ }^{2}$.

El reto que dejábamos anunciado para esta segunda parte consiste en analizar hasta qué punto en nuestra práctica judicial han sido recibidos los principios que inspiran a la jurisprudencia americana. Esta jurisprudencia está caracterizada por su vitalidad, su atención a la realidad y por la incorporación de una sensibilidad hacia los problemas y dificultades específicos de la administración de las compañías, que se trata de cohonestar con la defensa de los legítimos intereses de los accionistas y de los socios en gene-

${ }^{1}$ R. MúgiCA, Desde el Gobierno Corporativo a la responsabilidad de los administradores (I), en Estudios Deusto, vol. 57/2, julio-diciembre 2009, pp. 193-254.

${ }^{2}$ En la primera parte de este trabajo hacíamos una referencia expresa a la Gobernanza global también en el ámbito de la ética y el régimen jurídico de las sociedades mercantiles y, muy particularmente, en la regulación de la responsabilidad de los administradores. JeanClaude Trichet, el Presidente del Banco Central Europeo, recientemente ha insistido en esta idea. Hace un mes, según informaban los diarios, en un discurso ante el Council on Foreign Relations en Nueva York, el presidente del Banco Central Europeo, Jean-Claude Trichet, pidió la instauración de gobernanza global, comandada por el G20 y el Banco de Pagos Internacionales (BIS) en nombre de salvaguardar la economía global. 
ral. Por el contrario, se reprocha con frecuencia a nuestra judicatura que aborda las cuestiones de responsabilidad de los administradores con criterios excesivamente formalistas, poco adaptados a la realidad empresarial y a la sustancia económica de las cosas, cuya importancia tiende a exacerbarse en tiempos de crisis generalizada como los que ahora tocan.

El análisis que emprendemos en este segundo capítulo consistirá en un estudio esencialmente jurisprudencial, pues se centrará en el examen de las sentencias que en materia de responsabilidad de los administradores ha dictado en los últimos cinco años nuestro Tribunal Supremo. Nos proponemos investigar si existe una doctrina uniforme, consolidada y válida para el pronóstico, que constituya, además, una verdadera y útil pauta de conducta para los administradores; esto es, si puede deducirse un «estas son las consecuencias» para atenerse a ellas. En otros términos: si es identificable una línea jurisprudencial consistente que permita hacer pronósticos fiables a los letrados sobre el sentido de los fallos judiciales y realizar verdadera pedagogía para los administradores societarios. Y más allá de este primer objetivo, y en el caso de verificarse la existencia de una tal doctrina, cuáles son sus rasgos y hasta qué punto se reciben en ella las aportaciones más recientes de los autores y de los tribunales de otros países que están a la vanguardia en este campo.

Por qué limitaremos nuestra muestra a los pronunciamientos del Tribunal Supremo es algo que se puede responder con sencillez: primero, porque es el órgano jurisdiccional con mayor autoridad en la materia; y, segundo, porque abrir el foco para examinar las sentencias de otros tribunales y de los juzgados competentes desbordaría las posibilidades de un trabajo como el que ahora acometemos. La reducción de la muestra de decisiones judiciales al último lustro se justifica también por razones de abordabilidad y por la pretensión de ofrecer la fotografía más actual del estado de nuestra jurisprudencia.

En todo caso, antes de pasar a la exposición de la doctrina judicial, se hace imprescindible analizar la naturaleza de la relación administradorsociedad y recordar, aunque sea someramente, el instrumental legal con que jueces y tribunales se enfrentan a la cuestión de la responsabilidad de los administradores.

\section{Naturaleza de la relación administrador-sociedad mercantil}

¿Qué características presenta el vínculo entre el administrador y la sociedad en/para la que desempeña sus funciones? ¿La relación se establece propiamente entre el administrador y la sociedad o entre el administrador y los socios? La respuesta que se dé a estas preguntas va a condicionar, qué duda cabe, la naturaleza del vínculo y el contenido de la relación jurídica que se trabe por los administradores. Interesa examinar este asunto porque de ello depende cómo se modelen los derechos, obligaciones y responsabilidades de 
los administradores frente a los socios y el grado de exigencia de aquellos deberes.

1. Elementos subjetivos de la relación

Parece pacífico que la relación se establece entre el administrador y la sociedad y solo mediatamente o de manera indirecta entre aquel y los socios. A estos efectos cabe decir que la personalidad de los socios se difumina y pasa a volcarse en el esquema societario, en el de la institución o persona jurídica sociedad mercantil. Esta constatación no es irrelevante, pues va a orientar la actuación y obligaciones de los administradores: los administradores son, ante todo, servidores del interés social, entendido como interés de la compañía. Su misión consistirá, entonces, en promoverlo y protegerlo.

No obstante, la personalidad de los socios y sus intereses no se eclipsan del todo. Las decisiones fundamentales, las «estructurales», siguen confiadas a la voluntad mayoritaria de los socios, constituida y expresada a través de las juntas en el ejercicio del derecho de voto. Ciertamente, las minorías no contribuyen a formar la decisión societaria y las eventuales previsiones estatutarias que rompen la ecuación una acción-un voto ${ }^{3}$ representan excepciones a la proporcionalidad o relación directa entre participación en el capital (apuesta inversora) y participación en la formación de la voluntad. Pero fuera de estos casos, que se puede convenir en que resultan marginales, vale la conclusión de que los socios contribuyen a formular las grandes decisiones societarias de acuerdo con la medida de su participación en el capital.

2. Sobre el origen de la relación administrador-sociedad

Puede recordarse la vieja polémica acerca del carácter contractual o no del vínculo entre los administradores y la compañía, pero en este momento no parece útil detenerse en su exposición detallada. Cuando se niega la naturaleza contractual de esta relación es porque se hace hincapié en la idea de que su contenido se encuentra predeterminado por la ley, con carácter general, y por los estatutos de la sociedad, en particular. Es decir, la situación del administrador es «reglamentaria» o de adhesión a un estatuto previamente determinado. En puridad, se añade, la relación del administrador es orgánica, el administrador se incorpora a la organización de la sociedad y desempeña sus funciones en un régimen de adhesión a lo que hay, sin que pueda encontrarse atisbo de que se le reconozca capacidad configuradora del contenido del vínculo. De la misma manera que el funcionario o la autoridad administrativa ha de cumplir una misión y desempeñar las funciones del cargo en el régimen previa y objetivamente establecido, el administrador quedaría sujeto a un régimen de prestación de actividad que no contribuye a definir.

${ }^{3}$ Véase en la revista El Notario del siglo XXI, número 30, marzo-abril 2010, los enjundiosos artículos de LEÓN SANZ, «La prohibición de las limitaciones al derecho de voto», pp. 15 y ss.; VicEnt Chulí, One share onee vote en España, pp. 19 y ss.; y J. GARCÍA DE ENTERRÍA, «¿Deben prohibirse las limitaciones de voto de los accionistas?», pp. 26 y ss. 
Sin perjuicio de que esta concepción resulte dogmáticamente muy atractiva, no puede negarse que en el vínculo hay algún aspecto contractual. Ello se revela no solo en la necesidad de contar con la voluntad del administrador para que su designación o nombramiento resulten jurídicamente eficaces (y, por descontado, el peso de esa voluntad no siempre puede compararse con la que se requiere para llevar a efecto la provisión de cargos públicos), sino en la circunstancia, que no puede ignorarse, de que esa voluntad no sólo despliega una influencia en la generación del vínculo, sino en su futura conformación, es decir, en su reglamentación duradera. Sería ingenuo desconocer que en la práctica, en no pocas ocasiones, la persona a la que se hace el ofrecimiento del cargo de administrador pone sus condiciones, las cuales, de aceptarse, podrían resolverse en una reforma de las previsiones de los estatutos sociales que le afectarán o, incluso, en una «derogación» indirecta de las previsiones legales (por ejemplo, a través de concertar pólizas de seguro que le pongan a cubierto de responsabilidades legales derivadas del ejercicio del cargo, o mediante la previsión de indemnizaciones de cese que «frenen» el ejercicio del derecho de separación por los socios o «diluyan» en términos económicos los efectos de las responsabilidades que recaen sobre ellos). Por lo tanto, el esquema nombramiento-aceptación, en el que el peso de la vinculación se hace recaer enteramente en el acto unilateral del nombramiento y siendo la aceptación una mera condición, necesaria sí, pero puramente adhesiva, no deja de ser, si lo comparamos con el derecho vivido, una simplificación sobre el origen del vínculo, pues son muchas las veces que las cosas suceden de modo distinto a como sugiere tal mecanismo, bien porque la iniciativa del nombramiento parta del propio aspirante, bien porque las condiciones del vínculo se regulen, al menos en parte, para la ocasión, etc.

Entonces, la tesis ecléctica, que hace del vínculo administrador-sociedad una relación mixta orgánica-contractual, parece más ajustada a la realidad. Y parece más ajustada desde dos puntos de vista: primero, porque recoge en toda su amplitud las características del fenómeno, a saber: la inserción del designado administrador en una organización (aspecto institucional), lo que conecta con la atribución de una misión específica (y, por vía de consecuencia, de definición de competencias, derechos, obligaciones, responsabilidades, etc.), junto a la eficacia no solo para la incorporación, sino también reglamentado la relación, del designado administrador; y segundo, porque acierta a distinguir en el vínculo dos aspectos que, sin ser compartimentos estancos, dan una cabal y completa idea de las relaciones resultantes, y que son la relación existente entre la persona jurídica y el órgano formal, en primer término, y la que se refiere a la persona física o jurídica administradora y el complejo sociedad-órgano de administración. Indisociables una y otra en la realidad vital, pero no en un plano conceptual, y es esta posibilidad de discernimiento intelectual lo que puede ayudar a establecer con mayor finura y atención el régimen jurídico aplicable a la relación. El administrador es «absorbido» (¿abducido?) por la organización societaria a unos efectos; pero 
a otros mantiene su individualidad y su posición jurídica diferenciada «en» y también «frente» a la sociedad.

\section{El administrador gestiona intereses ajenos}

La relación jurídica administrador-sociedad pertenece al tronco de las denominadas de colaboración y dentro de estas a las de gestión de intereses ajenos. También gestionan intereses ajenos el mandatario (art. 1.709 del Código Civil), el comisionista (art. 244 del Código de Comercio), el agente (Ley 12/1992, de 27 de mayo, sobre Contrato de Agencia), el gestor en el caso de la gestión de negocios ajenos (arts. 1888 y ss. del Código Civil). En ninguno de estos casos se establece una relación orgánica entre el dominus negotii y el gestor, una incorporación de este al tejido orgánico de aquel. Tampoco se produce tal integración en las llamadas relaciones de fiducia, que, lejos de ser una figura marginal, experimenta una cierta revitalización merced a la extensión de la influencia del modelo norteamericano, a través de la relevancia que el concepto de los «deberes fiduciarios» asociados a los administradores societarios tiene en los Estados Unidos.

Conviene hacer alguna referencia a la fiducia. Entre las posiciones que tratan de explicar su verdadera naturaleza es predominante la tesis del doble efecto ${ }^{4}$ que, como es bien conocido, ve en el negocio fiduciario la yuxtaposición de dos negocios de diferente naturaleza y de distinto signo o sentido: un negocio real, traslativo y abierto, con eficacia externa, en virtud del cual se opera la transmisión de un bien a un tercero; y junto con él un negocio obligacional, de eficacia relativa (que solo vincula al tradens y al accipiens), reservado, que impone al adquirente la obligación de proceder, con relación

${ }^{4}$ De Castro y Bravo, El Negocio Jurídico, ed. Instituto Nacional de Estudios Jurídicos, Madrid, 1971, pp. 379 y ss.

La elaboración de la teoría y del régimen de la relación fiduciaria (fiduciary relationship) ha tenido su mejor exponente en el Derecho norteamericano. Para nosotros tiene interés esa relacion en la medida en que en su seno se desenvuelven los «deberes fiduciarios», que son los característicos deberes del administrador societario: cuidado o diligencia, fidelidad y lealtad. Inicialmente la relación fiduciaria estaba constituida por la categoría de los trustees, pero se expandió para abrazar a las relaciones de agencia (agency relationship y, con posterioridad, al vínculo entre los administradores sociales y la compañía, aunque en ocasiones esta tercera especie se presenta, no como un tipo independiente, sino como una derivación o subcategoría de las relaciones de agencia. En el caso del trustee hay posesión por una persona de bienes que pertenecen a otros o que han de palicarse en beneficio de este segundo (así, la fundación estaría próxima a la figura); en las relaciones de agencia se constata una actuación de un sujeto (el agente) en representación de otro, pero bajo el control de otra persona, siendo este dato del control la nota que caracteriza a la categoría. Cuando se trata de subrayar las diferencias entre la agencia y la relación del administrador se pone el énfasis en la idea de que el administrador no está sujetio al contro directo ni sobre él pesa la obligación de responder a la voluntad de los socios. Más clara aún resulta la diferencia con el trustee: el administrador no tiene derecho alguno sobre los bienes de la sociedad.

Véase CoOTER/Friedman, The Fiduciary Relationship, New Cork University Law Review (1991) 1046. También V. RIBAS FERRER, op. cit., pp. 72-73. 
al bien transmitido, según instrucciones reservadas del transmitente, instrucciones que con frecuencia consisten en la restitución del bien a este para cuando se cumplan determinadas condiciones. Este segundo negocio obligacional, en las relaciones entre partes, restringe la eficacia plenamente traslativa del primer negocio, el de naturaleza real, al limitar la posibilidad de libre disposición del bien por el accipiens. Como resultado final del negocio fiduciario cabe decir que «las cosas no son lo que parecen», pues la transmisión era solo aparente.

La base del negocio fiduciario es la confianza (de ahí la denominación de «fiduciario», como relativo a la fides o fiducia): confianza puesta en el adquirente por el transmitente; confianza de que no traicionará las instrucciones reservadas que le imparte y que son las que expresan que el verdadero poder de disposición, de señalar el destino final del bien o del interés, permanece bajo el gobierno de aquel transmitente.

Hay otras relaciones de gestión distintas de las arriba enumeradas. Se trata del grupo de gestores incorporados a las personas jurídicas. Entonces, como ya queda dicho, la relación adquiere una dimensión orgánica u organizativa. Nos encontramos aquí con el grupo de administradores de asociaciones, fundaciones y sociedades.

4. La relación del administrador societario es de tracto sucesivo, pues tiene vocación de continuidad o de permanencia en el tiempo.

5. Es una relación fiduciaria, como ha quedado señalado. Pero al resultar la confianza una nota esencial en ella y constituir un vínculo vocacionalmente duradero, algunos autores elevan la confianza a la condición de causa de la relación. De tal forma se refuerzan y relacionan el binomio relación fiduciaria-relación de tracto sucesivo. El resultado, en el plano jurídico, de esa sinergia, se traduce en la configuración del elemento causal. Y en cuanto causa no se limita a impulsar el nacimiento del vínculo, sino que también despliega una influencia permanente a lo largo de todo el ciclo vital de la relación. Por eso, los administradores están sujetos al poder de revocación de los socios o mandantes, a su moción de censura, que pueden ejercer libremente o ad nutum (así, en el art. 131 de la Ley de Sociedades Anónimas: «La separación de los administradores podrá ser acordada en cualquier momento por la junta general»).

6. Como actividad gestora que es la del administrador, consiste en servir intereses ajenos. No temamos en demorarnos acerca de este dato, y en dar algunas vueltas a su alrededor. El interés a servir se constituye en el eje de la figura y razón o fundamento de los deberes del gestor, esto es, del administrador en nuestro caso. Tratándose del administrador hay unos intereses nucleares y otros más periféricos. ¿A cuáles está obligado? Entre los intereses nucleares, claramente localizamos el propio interés personal del administrador, el de la sociedad y el de los socios. Más alejados de ese «centro» de intereses están los de «terceros»: trabajadores, Hacienda Pública, proveedores, acreedores, etc. La protección de estos últimos no la abandona el legis- 
lador; en el ánimo de defenderlos encuentran su razón de ser la legislación concursal, laboral, tributaria, etc. Pero los intereses próximos, inmediatos a la función del administrador, son los que primeramente hemos enunciado. No debe negarse la existencia de un interés personal. Tampoco se le escapa al legislador, que ha erigido el deber de lealtad como principio que viene a jerarquizar ese interés frente a los otros intereses en caso de conflicto entre ellos. Pero lo que debe precisarse es cuál es el interés (si el social o el de los socios) que ha de orientar y presidir la misión del administrador. El administrador público (esto es, la Administración Pública) sirve, por imperativo constitucional, los intereses generales (art. 103.1 C.E.), pero la indeterminación del concepto de interés general es más aparente que real, pues son las leyes y los tratados los que acaban definiendo, en un grado que hace asequible el concepto las más de las veces, en qué consiste el interés general para hacerlo una guía, una meta, razonablemente operativa y orientadora. En cuanto al interés al que deben servir los administradores, al menos en la letra de la ley queda claro cuál es: es el interés social, «entendido como interés de la sociedad» (art. 127 bis in fine de la LSA). Creo que con esta referencia literal la norma ha pretendido expresar una idea también en negativo: el interés de la sociedad no es el interés de los socios. No obstante, esta conclusión podría resultar artificiosa si nos atenemos a la realidad de los procesos, pues, desde un punto de vista vital (que no desde posiciones de abstracción), no se ve dónde pueda radicar la diferencia entre los intereses de la sociedad y los intereses de los socios... que constituyen la mayoría, pues al final (y salvo mecanismos correctores que rompan la idea de la asignación del poder de voto en proporción a la participación en el capital), es esa mayoría la que define, fundamentalmente, el interés de la sociedad y dispone del poder de revocación (precisamos, de separación) de los administradores. ¿En qué consiste el «interés social» en su acepción del interés de la sociedad? ¿En servir a los intereses de la mayoría, tal como se expresan en la junta de socios? ¿En perseguir la realización del objeto social, en la forma en que aparece definido en los estatutos, de la manera más eficiente -y si quiere añadirse, más ética y dentro, en todo caso, del marco del ordenamiento- de una manera sostenible? ¿En servir a la totalidad del cuerpo social, integrando como una variable más en el sistema del desempeño de la función la defensa de la posición de los socios minoritarios? La respuesta más integradora, la que sea capaz de incorporar todos los compromisos que se expresan en estas preguntas que acaban de ser formuladas, se presenta como la más adecuada. Por lo tanto, en la gestión de los intereses ajenos (los sociales) los administradores han de ser capaces de afrontar los siguientes retos: a) dar respuesta a las exigencias objetivas del desarrollo de la empresa que constituye la actividad u objeto social de la compañía; b) atender a los intereses de los socios, tal como se expresan en las decisiones adoptadas por mayoría de ellos, pero siempre salvaguardando los derechos esenciales de los minoritarios. Constituye una quiebra del derecho de estos últimos la presentación de reiteradas 
propuestas de no distribuir el beneficio que se produce recurrentemente pretextando necesidades de reforzar la estructura financiera de la compañía, porque ello es contrario a la esencia misma de la sociedad, cuya finalidad es no solo la de obtener beneficio o lucro (art. 116 del Código de Comercio), sino la de obtener lucro partible (art. 1.665 del Código Civil); constituye igualmente una lesión al derecho de los socios desarrollar una línea de negocio secundaria, dispensándole mayor atención y recursos que los que se aplican al ejercicio de la actividad que constituye el objeto principal de la compañía, al menos sin haber realizado antes los ajustes correspondientes en la definición estatutaria de la sociedad, a cuyo efecto la ley ya contempla una serie de cautelas o salvaguardas para proteger la posición del socio minoritario.

La pregunta que cabe añadir es si el administrador, en cuanto gestor de intereses de la sociedad (y, en segunda instancia, de manera derivativa, también de los intereses o inversión de los socios) es un gestor de carteras o, en algún grado, el principio rector de su actividad ha de asimilarse a la de un gestor de carteras o inversiones. ¿O es únicamente un gestor de empresa? Dejando de lado que con frecuencia convergirán interés de la empresa e interés de los socios (o, al menos, de la mayoría de estos), el «caso duro» se presenta cuando no hay tal coincidencia ${ }^{5}$, lo cual puede deberse al efecto del factor tiempo, pues no es la misma la paciencia del socio (a quien pueden interesar revalorizaciones rápidas de su cartera para liquidar en corto plazo) que la escala temporal que requiere un crecimiento y fortalecimiento sostenible de la empresa. Puede ocurrir que el accionista (sobre todo en el caso de tratarse de un inversor bursátil que aspire a ganancias inmediatas) prefiera matar la gallina para comer carne que dedicarla a ponedora. En estos casos, el dilema se resuelve de una manera clara: ha de primar el interés de la sociedad-empresa. Pero en la práctica sucede muchas veces lo contrario, pues acaba prevaleciendo el interés de los socios mayoritarios (que, a fin de cuentas, ejercen la presión de esa «espada de Damocles» en que consiste el poder de

${ }^{5}$ Sobre la posibilidad de la existencia de divergencia entre los intereses los socios que conforman la mayoría y el interés social (o de la sociedad) puede atisbarse una clara pista en el art. 115.1 de la L.S.A., relativo a los acuerdos impugnables adoptados en junta general, cuando establece que la pretensión podrá fundarse en que los acuerdos son contrarios a la Ley, se oponen a los estatutos o «lesionen, en beneficio de uno o varios accionistas o de terceros, los intereses de la sociedad». En este inciso entrecomillado se halla la clave: si los acuerdos se han producido es porque cuentan con la adhesión de la mayoría necesaria de los socios (que puede alcanzar, según los casos, el umbral de la mayoría absoluta o uno más elevado todavía), pero aún entonces pueden resultar contrarios al interés social. Por lo tanto, se verifica que interés de la sociedad no es igual a interés de la mayoría de los socios. Claro que el texto de la norma exige una condición adicional para este motivo de impugnación del acuerdo: que, además de la lesión del interés de la sociedad, dicha lesión se produzca en beneficio de uno o varios accionistas o de terceros (¿qué pasa entonces cuando solo se produzca en beneficio de los administradores?, ¿cabe considerarlos «terceros» a estos efectos?). 
remoción o separación frente al administrador no complaciente, sin desconocer, por otra parte, que son los propios administradores los que a través de diversos mecanismos son los que tienen el poder de conformar las mayorías que los sostienen), porque a la postre, en darles satisfacción encuentra el propio administrador la forma de preservar sus propios intereses personales ${ }^{6}$.

\footnotetext{
${ }^{6}$ De forma apasionada, como corresponde a una vivencia personal y a un largo itinerario de reivindicación de sus derechos como accionista, cabe recordar que solía asistir a las Juntas Generales de distintas sociedades cotizadas un socio que emprendió una cruzada personal frente a lo que él consideraba abusos de los administradores. Hace más de cinco años me hizo llegar un exhaustivo trabajo con la indicación de que no había encontrado editorial para publicarlo. Tiempo después había superado esta dificultad, según pude comprobar al ver el libro a a la venta. El trabajo es notable y, como propio de un ingeniero industrial, que no rehúye ningún campo (tampoco el legal) para la exploración y hasta para el combate, era minucioso y preciso. Puede uno cuestionar el manejo que hace de los conceptos generales que han de enmarcar la aplicación e interpretación de las reglas de detalle. Ese «chasis» principial es imprescindible para la correcta comprensión del ordenamiento, como no se escapa a ningún jurista. Fuera de eso el estudio de don J. M. Trevijano es muy interesante y, ¡qué duda cabe!, está inspirado por la mejor buena fe. Da pie a la reflexión y, si alguien pudiera achacarle ocasionales excesos, ofrece una imagen veraz y auténtica de las reales preocupaciones de un accionista monoritario en desigual lucha con las grandes plataformas societarias. La Introducción de la obra comienza así: «El presente trabajo tiene por objeto explicar cómo los administradores de unas pocas pero muy importantes sociedades anónimas que cotizan en Bolsa, proponen y aprueban en las Juntas generales de sus sociedades operaciones innecesarias para beneficiar a las sociedades que administran, pero que permite, si las ejecutan, su propio beneficio o el de terceros, con perjuicio para una parte, muy importante en número pero minoritaria en participación, de los accionistas a los que representan. Recurren además a prácticas contables incorrectas, que inflan los beneficios y perjudican a los inversores, en beneficio de aquellos a los que han otorgado stock options o retribuciones variables en función de los resultados, así como a los que han permitido suscribir emisiones en las que se han suprimido a gran número de accionistas de su derecho de suscripción. / Procuran generalizarlos, para que parezcan prácticas habituales correctas, en otras grandes sociedades cotizadas en las que tienen influencia. Se sirven del enorme poder económico de que disponen las empresas que administran, del prestigio personal que les proporciona la propaganda de unos medios de comunicación que o pertenecen a las mismas o necesitan de su cuantiosa inversión en publicidad, y de la falta de asociación e ignorancia excusable de los accionistas, puesto que por lo expuesto, los citados medios solo tienen libertad para informar en el sentido que a esos administradores interesa. Se han producido, tanto en la radio como en la prensa, hechos que lo prueban. Es cierto que en España tenemos libertad de expresión, pero el informar a los centenares de miles de accionistas que resultan perjudicados tiene un coste prohibitivo. Lo que no ocurre en el caso de los administradores, puesto que lo que les conviene comunicar se hace a costa de la empresa./ Lo verdaderamente grave es que con su enorme poder parece ser que controlan nuestras Instituciones y que si han incurrido en procedimientos, que vulneran la Directiva comunitaria, establecida para proteger los derechos de los socios, han tenido además influencia suficiente para que se modifique la Ley de S.A., a finales de 1998, de un modo que incurre en tentativa de vulnerar nuestro derecho constitucional y la declaración de Derechos y Libertades fundamentales del Parlamento Europeo, puesto que nunca puede haber interés de la sociedad que lo exija. Se ha originado un gran escándalo en el extranjero por los perjuicios que
} 
$\mathrm{O}$ acaso habría que replantear el enfoque y, aplicando también aquí el método del «levantamiento del velo», concluir que la sociedad no es otra cosa que una pantalla interpuesta y que no hay más interés real que el de los socios o inversores finales, pues el recurso a la constitución de la sociedad es un expediente puramente instrumental. No parece que sea así en nuestro ordenamiento, una vez que se ha constitucionalizado el valor empresa, la defensa de su productividad y de la participación en ella (arts. 38 y 129.2 C.E.) que, por trascender los intereses inversores de los socios o accionistas, aparece vinculado en el caso que analizamos primariamente a la sociedad titular antes que a los socios, y «por encima» de estos. De algún modo es como si la empresa se institucionalizara y se colocará un peldaño más arriba que los intereses individuales de los socios.

En fin, aunque no solo, el verdadero dominus, el dueño principal del negocio en la relación de gestión que vincula al administrador, lo es la sociedad.

7. La función de administración que corresponde a los administradores constituye un área reservada a ellos, en la que no se admiten injerencias de la junta de socios ${ }^{7}$, fuera del control que se realiza a través de la acción de responsabilidad; del escrutinio, apoyando o rechazando en Junta las propues-

algunos administradores han originado a los pequeños accionistas. Pero es mucho más grave lo que en España está sucediendo de que esos perjuicios se efectúen ante la inhibición y en algún caso cooperación de las Instituciones que debieran protegerles». Véase J. M. TREVIJANO ETCHEVERria, Contra la corrupción en la administración: defensa de los accionistas minoritarios frente a las grandes corporaciones, ed. Libroslibres, Madrid, 2007.

${ }^{7}$ Sin embargo, tratándose de la sociedad limitada, la reserva queda debilitada, aunque este decaimiento queda abierto a la disposición de los estatutos. El art. 44 LSRL, después de relacionar en su punto 1 los asuntos competencia de la Junta General (por cierto, con una cláusula abierta en su último apartado o letra h), según el cual la competencia se extiende por fin a «cualesquiera otros asuntos que determine la ley o los estatutos» -lo que lleva al ánimo la idea de que solo la atribución expresa y positiva dota de competencia a la Junta, por lo que, a falta de ulteriores matizaciones y excepciones, la competencia residual o implícita ha de residenciarse en el órgano de administración en cierta medida abierta a la disposición de los estatutos; el artículo 44 LSRL, proseguimos, añade. «Además, y salvo disposición contraria de los estatutos, la Junta General podrá impartir instrucciones al órgano de admnistración o someter a autorización la adopción de por dicho órgano de decisiones o acuerdos sobre determinados asuntos de gestión», sin perjuicio de reconocer que la representación orgánica (y típica o inderogable frente a terceros por su ámbito objetivo) corresponde a los administradores. Apunta así el precepto a la posibilidad de una gestión compartida o bicéfala (aunque no tal vez en condiciones de estricta paridad). No acota el ámbito material en el que esa concurrencia gestora puede operar; no hay límite, salvo los que acaso se deduzcan del esquema orgánico esencial que el legislador tenga en mente y cuya ruptura desnaturalizaría el mismo concepto de sociedad. Las únicas exigencias al respecto son de tipo formal: que la delimitación de materias sea conforme al principio de especialidad o determinación (pero no se pone coto al quantum) y que tal especificación se haga en los estatutos sociales. 
tas de acuerdo presentadas por los administradores; y del poder de separación o remoción. Existe aquí por lo tanto también una expresión del principio de separación de poderes: la gestión para los administradores. Lo que es cierto en el ámbito interno (o de la administración propiamente) se refleja también hacia el exterior, en las relaciones de representación o actuación frente a terceros: la representación (orgánica) de la sociedad, «en juicio o fuera de él, corresponde a los administradores en la forma determinada por los estatutos» (art. 128 de la L.S.A.). Como la esfera interna exclusiva del administrador alcanza a todo el ámbito de la gestión, lo mismo sucede en el caso de las relaciones de representación: por eso únicamente los administradores pueden nombrar apoderados o representantes voluntarios. Porque solo el que tiene puede dar.

El ámbito reservado a los socios que constituyan mayoría queda pues delimitado por la función de control del órgano de administración y por los aspectos estructurales del contrato de sociedad, pues para la modificación de sus términos fundamentales se requiere de su participación.

8. El contenido de la relación del administrador se resuelve en una obligación de medios. Es la actividad, no el resultado, lo que moldea el contenido de dicha relación, si bien conviene llamar inmediatamente la atención sobre una circunstancia por lo demás obvia: que la falta de resultados presupuestos se puede sancionar por la mayoría social en el ejercicio del poder de separación.

9. Lo que acaba de afirmarse conduce a analizar otro rasgo caracterizador de la relación del administrador. Este se encuentra sometido a escrutinio permanente de la mayoría social. Es esta mayoría la que designa a los administradores $^{8}$ (para la sociedad anónima, la regla general está contenida en el art. 123.1 L.S.A.) y los separa libremente en cualquier momento (art. 131 L.S.A.). La posibilidad de revocación incondicionada es propia de las relaciones de confianza (es así que el art. 1732.1. ${ }^{\circ}$ del Código Civil establezca como primera causa de extinción del mandato la revocación, revocación que puede adoptar el mandante «a su voluntad», según precisa, quizás redundantemente, el siguiente artículo 1732).

Por lo tanto, el administrador está expuesto de manera constante al voto de censura de la mayoría y, en este sentido formal, su posición es precaria.

10. Conviene detenerse ahora en las características de la actividad llamada a desempeñar el administrador. No basta decir que es una actividad de medios, que consiste en la gestión de intereses ajenos (principal y específicamente los de la sociedad; derivativamente, los de todos los socios), que se realiza bajo el examen de la mayoría social, etc. ¿Cuál es el contenido pro-

${ }^{8}$ Las excepciones, tratándose de sociedades anónimas, vienen constituidas por la posibilidad de representación proporcional (art. 137 L.S.A.) y, en menor medida en razón del carácter provisional del nombramiento, por el sistema de cooptación (art. 138 L.S.A.). 
pio de la función administradora y en qué condiciones se realiza? ¿Cuáles son sus límites? Vayamos por partes.

a) El estatuto delimitador de la actividad del administrador está constituido por las leyes (especialmente las reguladoras del tipo social correspondiente, pero no solo ellas), por los estatutos y por las del «contrato» que subyace a su nombramiento. Así, de la ley se derivan los deberes generales, ya conocidos, de diligencia, fidelidad y lealtad, y una multitud de deberes particulares concretos, bien de índole material, bien formales. Pero los estatutos (y eventualmente las disposiciones de origen societario que los desarrollan, como el reglamento del consejo u otras similares) suelen contener profusión de previsiones que se refieren al régimen de actuación del administrador y no es la menos importante la definición del objeto social, en cuanto delimitadora del campo de actividad empresarial.

No obstante, el régimen escrito no es suficiente. Aquí también resulta de aplicación el uso o la costumbre (art. 2 Código de Comercio) que ayuda definitivamente a discernir las buenas de las malas prácticas de administración, a precisar el grado de lo exigible en función de circunstancias o casos particulares que no ha contemplado la ley y a integrar las fórmulas vagas que en ocasiones figuran en el texto de la norma. Los grandes fines a que ha de encaminarse el gobierno que desempeñan los administradores resultan de los estatutos y se actualizan en la junta general de los socios. Esta voluntad mayoritaria social constituye, pues, un nuevo elemento que enmarca la actuación gestora. Y la resultante de la acumulación de todos los vectores expresados se identifica con el interés social, en definitiva.

11. Interesa ahora hacer algunas consideraciones sobre los aspectos materiales de la función de administrar. Sabemos que el administrador gestiona y, además, que le corresponde en régimen de reserva la representación orgánica de la sociedad. Pero ¿qué es administrar más allá de ocuparse o gestionar los intereses ajenos? Hay un contenido mínimo o consustancial a la función de administrar y que consiste en contribuir a definir, dentro del marco del objeto social definido estatutariamente, las grandes líneas estratégicas de la actividad empresarial; las líneas gruesas de la financiación; desarrollar la vigilancia y supervisión del funcionamiento de las áreas de la empresa; la política general de cumplimiento de la legalidad; el aseguramiento de la relación entre la empresa y los socios, que encuentra su ocasión culminante en la celebración de la junta. Y también la administración obliga a promover el pronunciamiento de la junta en asuntos de su competencia cuando ello convenga a la realización de los planes estratégicos. Dentro de estos cometidos, y ya ahora desde un punto de vista funcional, las anteriores tareas se canalizan a través de la supervisión o vigilancia, con su secuela de solicitar información; el nombramiento de altos cargos o personal directivo y seguimiento de su desempeño; la atención continuada a la marcha de la empresa; la relación con los socios o accionistas. 
Lo que no queda definido en las fórmulas anteriores es cuál es el grado de cumplimiento que en las distintas tareas y ejercicio de las funciones encomendadas es exigible a los administradores; esto es, el quantum o nivel de responsabilidad. La respuesta no puede ser aritméticamente exacta, pero sí es posible señalar unas pautas que hacen al menos determinable esa medida de la responsabilidad. Por lo tanto, el relativismo no es absoluto, los factores de graduación de la responsabilidad pueden objetivarse. Estos serían los siguientes según entiendo: a) la dimensión de la empresa, pues lógicamente el grado de exigencia de responsabilidad del administrador ha de diluirse cuanto mayor sea su complejidad (no se le puede exigir, cuando se trate de una macroempresa, un conocimiento exhaustivo de los pormenores o detalles más ínfimos o coyunturales de la marcha de la sociedad); b) el diseño del órgano de administración, pues no es igual que sea colegiado y cuente con un reparto de funciones, con una división de trabajo, en definitiva, que haga más racional y asequible el desempeño de la administración, que concentre en un solo administrador único todo el peso de la función; c) el carácter retribuido o no del cargo (ver a este respecto el artículo 130 de la L.S.A.), pues el vínculo beneficio-exigencia debe traducirse en mayor responsabilidad del administrador remunerado, al contribuir la retribución a profesionalizar el desempeño de la función, generando así una responsabilidad agravada.

En cuanto al diseño del órgano de administración, además del margen que la ley deja a la libre disposición estatutaria, e incluso al órgano de administración para autorregularse (si bien, tratándose de sociedades cotizadas, es obligado que el consejo de administración, con informe a la junta general, dicte un reglamento de normas de régimen interno y funcionamiento del propio consejo, «que contendrá las medidas concretas tendentes a garantizar la mejor administración de la sociedad» ${ }^{9}$, según reza el art. 115 LMV), existen previsiones imperativas que vienen a reforzar la estructura organizativa prevista en el régimen común de las sociedades anónimas. Así, las sociedades bursátiles o cotizadas (y no solo ellas, sino todas las entidades emisoras de valores admitidos a negociación en mercados secundarios oficiales de valores), han de constituir un Comité de Auditoría (Disposición Adicional 18. ${ }^{\mathrm{a}}$ de la LMV). A todo ello han de añadirse las previsiones de organización más oficiosas - menos formalizadas-, como pueden ser la distribución de facto de áreas de responsabilidad entre los distintos miembros del consejo de administración.

En todo caso, la imagen resultaría incompleta si no añadiéramos una variable decisiva. No toda la responsabilidad de la administración es de los administradores, porque es la junta de socios la que los nombra y los separa (poderes que, respectivamente identifican una responsabilidad in eligendo e

\footnotetext{
${ }^{9}$ Repárese en la «carga» dispositiva de este precepto: medidas tendentes a «garantizar la mejor administración de la sociedad» $\mathrm{y}$, además, ¡medidas que sean «concretas»!
} 
in vigilando), también pesa sobre ellos una responsabilidad. Ocurre simplemente que la sanción por el desfallecimiento en el ejercicio de sus responsabilidades no es de tipo formal sino económico y se traduce en la pérdida de valor de su inversión o participación social. La responsabilidad de los gestores se actúa, como después veremos, a través de otros mecanismos.

Adquiere así la designación o nombramiento de los administradores una relevancia extraordinaria, lo que no deja de ser una constatación obvia. Fuera de los casos de autonombramiento (porque el interesado cuenta por sí o en combinación con alianzas y apoyos de otros socios, con la mayoría suficiente), los conocimientos, experiencia, carácter y otras cualidades personales han de presidir la elección de administrador. Los socios han de pechar con las consecuencias adversas de un nombramiento desafortunado o negligente, sin perjuicio de la posibilidad de rectificarlo por la expeditiva vía del ejercicio del poder de separación.

Por último, la nota que más arriba dejábamos apuntada sobre el ámbito de actuación de los administradores que les queda reservado y que resulta inmune a la intervención de los socios está apelando directamente a la idea de una actividad especializada y que reclama un cierto ámbito de libre decisión. Aquí también podría utilizarse la idea de discrecionalidad técnica (algunos autores se refieren indistintamente a discrecionalidad o autonomía), que en el Derecho Administrativo sirve para definir un ámbito de actuación exento de la intervención o control judicial, por ser lo más específico de la función separada de administrar. En ese ámbito no cabe reproche jurídico, salvo sea de nuevo el poder de separación de la mayoría societaria, que puede ser ejercido, legalmente, de manera objetivamente arbitraria o caprichosa.

\section{Precisiones adicionales sobre el propósito y el ámbito del estudio}

Ceñiremos nuestro estudio al régimen legal de las grandes sociedades, las sociedades anónimas cotizadas. No obstante, cabe hacer desde este mismo comienzo dos precisiones al respecto: a) que el régimen fundamental de la responsabilidad es coincidente, en su formulación abstracta, para las grandes y para las sociedades anónimas menores; b) que, como revelará el posterior examen de la jurisprudencia acotada, la litigiosidad se produce con una frecuencia relativa realmente insignificante cuando se trata de las grandes sociedades. Esto último puede deberse a que hay menos motivos para exigir responsabilidades al administrador de la gran sociedad, o a que en esta escala de sociedades juegan elementos o factores disuasorios, de carácter metajurídico, que dificultan la presentación de demandas de responsabilidad. Aún podría imaginarse sobre que el complejo sociedad-administrador se defiende mejor, con más contundencia, ante las exigencias judiciales de responsabilidad en sociedades de este tamaño, por lo que el «salto» hasta la instancia casacional queda más desincentivado que en sociedades de otra dimensión. 
En todo caso, la corroboración de esta hipótesis nos llevaría a realizar un análisis de la estadística de juzgados y tribunales en las distintas instancias que por el momento no estamos en condiciones de iniciar y que, además, nos distraería del objetivo que nos hemos propuesto para el presente trabajo.

La responsabilidad es el reverso, la cruz de la moneda cuya cara está representada por el deber u obligación. El incumplimiento del deber, salvo en el caso de la norma imperfecta, constituye la causa de la responsabilidad. Sabido es que la llamada ley de transparencia, la Ley 26/2003, de 17 de julio, por la que se modifican la Ley del Mercado de Valores y la Ley de Sociedades Anónimas con el fin de reforzar la transparencia de las sociedades anónimas cotizadas, multiplica el originario artículo 127 en los 127, sobre el deber de diligente administración; 127 bis, sobre deberes de fidelidad; 127 ter, deberes de lealtad; y 127 quáter, sobre deber de secreto. Los dos últimos preceptos, señaladamente el 127 ter, tienen considerable extensión.

En la primera parte de nuestro trabajo hemos apuntado algunas ideas para la interpretación de los artículos reseñados. Interesa retener ahora que estos deberes contenidos en la familia de los artículos 127 establecen más la «forma» en que los administradores deben actuar que el contenido concreto de esos deberes. Efectivamente, el «qué» hay que buscarlo en las legislación -no solo en las normas societarias ni tan siquiera en las mercantiles; también en las tributarias, en las laborales, en las administrativas, etc.- y en los estatutos sociales, como bien resulta del art. 127 bis de la Ley de Sociedades Anónimas: «los administradores deberán cumplir los deberes impuestos por las leyes y los estatutos...» ${ }^{10}$.

\section{Los deberes generales del administrador: diligencia, fidelidad y lealtad ${ }^{11}$}

Con la reforma de la LSA por la llamada «ley de transparencia» de 2003, los deberes generales (relativos, según ha quedado ya indicado al «cómo»

\footnotetext{
${ }^{10}$ La doctrina ha analizado la tríada de deberes de diligencia, fidelidad y lealtad del administrador societario con una doble metodología: a) la de la visión conjunta, que suele resolverse en una visión equilibrada de los tres que, además, señala las conexiones entre ellos y sus recíprocas relaciones, resultando de esta forma de aproximación una visión sistemática e integradora; b) focalizando la atención en uno de esos tres deberes, lo que con frecuencia produce la perversión que denominaré del «triángulo giratorio». Según cuál sea el deber objeto de consideración separada (diligencia, fidelidad, etc.), una especie de inercia intelectual acaba haciendo de él la base y soporte de todos los demás, el centro del sistema, y ese deber en cuestión «satelitiza» o fagotiza a los otros dos. No sucede así, sin embargo, en V. RIBAS FerRer, El Deber de Lealtad del Administrador de Sociedades, ed. La Ley, Madrid, 2010. Utilizaremos en el presente trabajo abundantemente algunas de las aportaciones que contiene esa obra.

${ }^{11}$ La bibliografía sobre el tema es muy abundante. La obra de referencia, que realiza el estudio sistemático de estos deberes generales, es J. I. FonT GALÁn, El deber de diligente administración en el bnuevo sistema de deberes de los administradores sociales RdS 25
} 
deben actuar, no al «qué» deben hacer) de los administradores quedaron formulados en el tríptico diligencia, fidelidad, lealtad ${ }^{12}$. Ahora bien, no es cosa simple establecer el cuadro sistemático de estos deberes, es decir, el conjunto de sus relaciones recíprocas. En la exposición de la doctrina nos encontramos explicaciones que no satisfacen la propiedad transitiva, pues llega a decirse que la lealtad es madre de la diligencia y esta de la fidelidad, pero a la vez la fidelidad es el tronco del que deriva de lealtad. Y ya es una familia revuelta aquella en que la abuela es a la vez hija de su nieta. Dejando de lado estos problemas de genealogía y de causalidad (qué es causa y qué es efecto), acaso una vía útil para aproximarnos al concepto y aplicación de los tres dichos deberes consista en atender a qué interés se trata de proteger con cada uno de ellos y de qué manera actúa cada deber en relación con el interés a que aparece asociado. Con pretensión nada más que exploratoria creo que se pueden establecer las siguientes aproximaciones: I) los tres deberes coadyuvan a la defensa y promoción del interés social; II) el deber de fidelidad tiene como vocación la promoción y defensa del interés social de manera absoluta, en todo caso, y no solo en situaciones de conflicto con otros intereses, pero su caracterización cabe completarla con una nota adicional: su proyección negativa, en cuanto que se resuelve en un no realizar lo que dañe al interés social; b) el deber de diligencia tiene una clara dimensión positiva, que se traduce en un «hacer» o conducta positiva, y en hacerlo con cuidado, oportunidad, información, previsión. No basta pues con evitar el mal o el daño a la sociedad (deber de lealtad); hay además que hacer el bien o lo mejor posible en pro del interés de la sociedad ${ }^{13} ; \mathrm{c}$ ) en fin, el deber de leal-

(1005) 86, pp. 71 y ss., ya citado en la Parte I de este trabajo. Entre los estudios recientes, además, V. RIBAS FERRER, op. cit. y E. BELTRÁN y otros, La responsabilidad de los administradores de las sociedades mercantiles, ed. Tirant lo Blanch, Valencia, 2009, pp. 26 y ss.

${ }^{12} \mathrm{La}$ «Ley de transparencia» se refiere a un cuarto deber general en su artículo 127 quáter: el deber de secreto. No ponemos en cuestión su trascendencia, pero nos parece «menos general» que los otros tres y, además, subsidiario del de diligencia. Porque si la diligencia obliga a cada uno de los administradores a informarse diligentemente sobre la marcha de la sociedad (art. 127.2 L.S.A.), ello significa que constituye el de información un derecho-deber que permitirá, ordinariamente, al administrador acceder a información sensible, esto es, conocer datos que, mal utilizados, pueden ocasionar perjuicio al interés social. Por eso, más parece que el deber de secreto sea una cautela o contrapeso al poder-deber de información.

${ }^{13}$ En el Diccionario de la Real Academia de la Lengua no encontramos ayuda para sustantivar el deber de fidelidad frente al de lealtad, ya que para la definir la voz «infiel» utiliza el adjetivo «desleal». En el evangelio de San Lucas, en el pasaje del administrador infiel, sin embargo, podríamos hallar una clave para el deslinde entre los dos conceptos y así, si la lealtad consiste en dar prioridad al interés del principal cuando entra en conflicto con el interés personal del gestor, la fidelidad podría referirse a otro conflicto de intereses, aquel que enfrenta al interés del principal, no con el del gestor, sino con el de terceros, conflicto que ha de resolverse concediendo preferencia y sirviendo mejor, por ende, al interés del principal (de la sociedad, en nuestro caso). En Lucas 16, leemos: «Y dijo también a sus discípulos: 
tad plantea una situación de conflicto o de balance entre el interés social y el personal del administrador, y se resuelve en la fórmula de que en la actuación del administrador ha de pesar siempre más el primero que el segundo y, además, no debe poner en peligro el interés social por razón del particular.

Las dificultades de deslindar entre los deberes de lealtad y de fidelidad han llevado a algunos autores a elidir, simplemente, uno de los $\operatorname{dos}^{14}$. En todo caso, la «asimilación» intelectual de esta compleja trinidad diligencia-fidelidad-lealtad no es cosa sencilla. Las implicaciones y conexiones, incluso a nivel de texto legal, entre unos y otros deberes, es manifiesta (así, la diligencia exigible al administrador por el art. 127 de la L.S.A. es, además de la que corresponde al ordenado empresario, al representante «leal»), pero lo que debe preocuparnos muy particularmente es si resulta operativa o distorsionadora la concatenación de los tres conceptos. Es decir, si posee sentido o la fórmula es puramente reiterativa (o, al menos, parcialmente repetitiva), una superposición de reglas de conducta que se solapan sin más lógica que la que sea capaz de asignarle el intérprete (racionalidad en destino, no en la fuente). Por eso se hacía necesario ensayar una fórmula de racionalización.

a) El deber de cuidado o diligencia. El contenido y el grado de exigencia de este deber quedan moldeados por el interés al que sirve, pero no solo. También por el «qué», esto es, por el deber material concreto de que en cada caso estemos hablando y por las circunstancias particulares que concurran. La ley, inevitablemente, no puede llegar más lejos en la cuantificación del deber exigible que lo que permite el recurso a imaginarios o arquetipos de conducta que, presumiblemente, cuentan con la legitimación que les proporciona una cierta tipificación social. Así, el buen padre de familia (art. 1.104

\footnotetext{
"un hacendado tenía un administrador y este fue denunciado como malversador de sus bienes. Lo llamó y le dijo: ‘¿Qué es lo que oigo de ti? Dame cuenta de tu administración, porque ya no puedes seguir de administrador': ‘Qué haré si mi amo me quita la administración? Cavar, ya no puedo; mendigar me da vergüenza. Ya sé qué haré para que me reciban en sus casas cuando no tenga la administración'. Llamó a todos los deudores de su amo y dijo al primero: ‘¿Cuánto debes a mi amo?’. Él contestó: 'Cien batos de aceite'. 'Toma, le dijo, tu recibo, siéntate y escribe enseguida cincuenta'. Y luego dijo a otro: ‘¿Y tú cuánto debes?'. Él respondió: 'cien coros de trigo'. 'Toma, le dijo, tu recibo y escribe ochenta'”. El amo alabó al mayordomo infiel, porque había obrado sagazmente. Pues los hijos del mundo son más sagaces para sus cosas que los hijos de la luz...». Siempre quedará la duda de la causa por la que se tiene al administrador por infiel: si se encuentra en el origen de la reprimenda, esto es, en la malversación de los bienes del hacendado, o si en la estrategia de «salida» que se procura el administrador: servir mejor a terceros (y de paso a sí mismo) que a su amo. Parece que en lo primero, pero en lo segundo, en traicionar los intereses del principal que ha confiado en él, por los de terceros, creo que puede estar la esencia de la infidelidad. ¡Y no solo en el ámbito de las relaciones económicas!

${ }^{14}$ Véase en E. Beltrán y A. Rojo (directores), op. cit., J. ORIol Llebot, Deberes y responsabilidad de los administradores, pp. 26 y ss.
} 
del Código Civil), la diligencia profesional y, en lo que ahora nos concierne, las de un ordenado empresario (¿es el administrador el empresario?) y la de un representante leal (art. 127 L.S.A.). Repárese de paso en que el deber de diligencia es uno, los de fidelidad y lealtad se escriben en plural en la rúbrica de sus respectivos artículos (127 bis y 127 ter).

Para concluir esta referencia al deber de diligencia parece preciso subrayar la importancia que las técnicas organizativas pueden desempeñar en observancia o cumplimiento. Además de las ya previstas en la ley -para las sociedades cotizadas, tales como la necesidad de contar con una comisión de auditoría, otra de nombramientos, una proporción de consejeros independientes, elaborar el informe Anual de Gobierno Corporativo (con un contenido mínimo y típico), siempre se pueden arbitrar métodos adicionales, y ente ellos parecen muy indicados los sistemas de evaluación periódica de los administradores.

b) El deber de fidelidad. Como emanación del deber general de buena fe (que el art. 7.1 del Código Civil refiere al ejercicio de los derechos), con una manifestación amplia en el campo de la contratación y el cumplimiento de las obligaciones (art. 1.258 del Código Civil y 57 del Código de Comercio), se proyecta sobre las funciones del administrador el deber de fidelidad: no hacer daño al interés del principal, cuidar del negocio, del interés ajeno, como si fuera propio.

Este deber de fidelidad, en el caso de la sociedad mercantil, no es exclusivamente deber del administrador. Sujeta primeramente al socio; cualificadamente al socio de control; y, aún con mayor intensidad, y expresamente recogido en la letra de la ley, al administrador.

c) El deber de lealtad. RIBAS FERRER define el deber de lealtad como «la obligación de todo gestor de actuar en interés del principal en caso de conflicto de intereses, subordinando los propios intereses a favor de los intereses a favor de los intereses del principal, salvo que, previo disclosure del gestor, el principal autorice su actuación interesada» ${ }^{15}$.

Una visión comparatista nos muestra las grandes diferencias que existen entre los ordenamientos nacionales en la regulación de las obligaciones de lealtad. Nos encontramos algún país que codifica en cuanto tal el deber general de lealtad, pero esto es la excepción. Lo más frecuente es que se adopte el sistema de ir describiendo posibles supuestos de conflicto, que no coinciden necesariamente de un país a otro. También se indica que al día de hoy el Derecho de la Unión Europea no constituye, a diferencia de lo que sucede con otras materias, una referencia cuya aportación tenga especial significado $^{16}$.

${ }^{15}$ V. RIBAS FERRER, op. cit., p. 218.

${ }^{16}$ V. RIBAS FERRER, op. cit. 
Ya hemos dejado más arriba señalado que el ámbito propio del deber de lealtad es el de la tensión o conflicto entre el interés personal del administrador y el interés social, si bien en algunos ordenamientos se ha matizado más el supuesto y la idea de «dualidad» de intereses ha venido a sustituir a la del «conflicto» o contraposición ${ }^{17}$. El contenido concreto del deber de lealtad suele exponerse a través de una serie de conductas concretas prohibidas $\mathrm{u}$ obligadas. Así, la prohibición de realizar ciertas operaciones con la sociedad (autocontratación, obtener préstamos o garantías de la compañía), la de concurrir o competir con la sociedad en el desarrollo de su actividad propia, la de aprovechar ciertas oportunidades de negocio prevaliéndose de su condición de administrador. En este plano concreto también las legislaciones suelen prestar especial atención al régimen de los contratos que celebra el administrador con la sociedad. Además, establecen una serie de mecanismos (preventivos o subsiguientes) que ayudan a controlar las situaciones que constituyen una amenaza objetiva para la observancia del deber de lealtad. Así, la necesidad de manifestar el administrador la posición que le afecta y que puede comprometer la defensa del interés social porque se enfrenta al suyo propio (disclosure); la necesidad de obtener autorización (ordinariamente de la junta de socios) con carácter previo a realizar determinadas operaciones; la abstención de votar en asuntos que afecten a su interés; la responsabilidad por el daño causado y la restitución del beneficio indebidamente obtenido. Y a ello se añade la previsión de la protección del tercero de buena fe o desconocedor de que en el contrato con él celebrado por el administrador en representación de la sociedad concurría un interés espurio que afectaba a la validez del negocio.

La Sociología Jurídica ha identificado y clasificado las situaciones de conflicto de interés. La tipología resulta de lo más variada. Los conflictos pueden ser actuales o potenciales; directos o indirectos; permanentes u ocasionales; relativos a relaciones jurídicas o a situaciones de hecho. También ha realizado el inventario de los posibles supuestos de conflicto de interés: uso indebido de información (especialmente con incidencia en los mercados de valores); uso interesado de bienes y servicios de la sociedad; aprovechamiento de bienes y servicios de la compañía; competencia o concurrencia con la sociedad; y, de muy destacada trascendencia, el caso de la contratación, con su variedad de autocontratación (autoentrada y aplicaciones bursátiles incluidas), contrato de remuneración de los administradores, de seguros, indemnizaciones por cese anticipado, pensiones, etc.

Ha sido en Norteamérica donde el análisis y construcción del régimen de la desviación de poder ha experimentado un mayor desarrollo. Allí el deber

${ }^{17}$ Art. 2391.I del Codice Civile, según redacción introducida por el Decreto Legislativo de 17 gennaio 2003, número 6, de Reforma Orgánica de la Disciplina de la Sociedad de capital y de la sociedad cooperativa, en ejecución de la ley de 3 de octubre de 2001. 
de lealtad se enmarca en la teoría de los deberes fiduciarios, deberes estos que se localizan en el seno de una relación de delegación de poderes realizada en el mejor interés de otra persona y los poderes objeto de delegación lo son para influir y modificar la esfera correspondiente a ese «otro». Inmediatamente se plantea entonces la posibilidad del riesgo de abuso del poder.

Los deberes fiduciarios son el deber de cuidado y el deber de lealtad. El contenido de este último presenta una doble vertiente: a) por una parte, la prohibición de actuar en situaciones de conflicto de interés; y b) por otra, el gestor no puede colocarse en una posición que le permita obtener beneficios ocultos o ventajas personales no autorizadas («secret profits»), salvo información previa a los socios (disclosure) y autorización de ellos. El Derecho norteamericano se sirve fundamentalmente de dos mecanismos para controlar el riesgo de deslealtad:

I) en primer lugar, la regulación de la contratación interesada del administrador con la sociedad. Esta regulación presenta una clara evolución, pues desde la prohibición absoluta de contratación en una primera fase, se pasa después al principio del fairness test (son válidos los contratos equitativos que resulten de interés para la sociedad);

II) en segundo lugar, ahora en el campo de los conflictos de carácter no negocial (corporate opportunities), el régimen, de construcción jurisprudencial, no resulta del todo claro y preciso. Según este cuerpo de decisiones judiciales es preciso, como paso previo, establecer cuáles son los presupuestos necesarios para poder definir lo que es una oportunidad de negocio. Los presupuestos son básicamente tres: uno, el del interest, expectancy or necessity test, según el cual una oportunidad social es una oportunidad de negocio en que la sociedad tiene un interés actual o potencial o es una oportunidad necesaria para el desarrollo del objeto social; dos, line of business, según el cual una oportunidad social o de negocio es no solo la que forma parte del objeto social, sino aquella que atiende a los medios realmente disponibles para saber si con ellos se satisfacen los fines societarios (así, no habría deslealtad ni oportunidad de negocio desleal si, a pesar de que la actividad acometida por el administrador en su propio interés forma parte del objeto social tal como este es canónicamente definido por los estatutos, los medios de hecho disponibles por la sociedad impiden a esta acometer la oportunidad del negocio en cuestión); por último, el fair test, que constituye esencialmente un criterio ético, de suerte que no es oportunidad de negocio desleal aquella iniciativa que, atendiendo a las circunstancias concretas del caso, resulta justa y equitativa.

El administrador puede oponerse frente a las acciones contra él promovidas por aprovechamiento indebido de oportunidad de negocio (sanciones que consistirán en la exigencia de responsabilidad por daños y en la restitución de la ganancia) alegando autorización de la sociedad, incapacidad económica o imposibilidad de la sociedad para aprovechar la oportunidad y abandono o rechazo de la oportunidad por la sociedad. 
Entre nosotros, con la reforma operada por la Ley 26/2003, de 17 de julio, la denominada «ley de transparencia», se introdujo en la L.S.A. el artículo 127 ter que, en plural, regula los «deberes de lealtad». No existe propiamente en el texto legal una caracterización abstracta de este deber (una cláusula general), pero sí un inventario de su contenido. En este inventario identificamos elementos a los que nos acabamos de referir: 1) los administradores no podrán utilizar el nombre de la sociedad ni invocar su condición de administradores de esta para la realización de operaciones por cuenta propia o de personas a ellos vinculadas; 2) ningún administrador podrá realizar, en beneficio propio o de personas a él vinculadas, inversiones ${ }^{18} \mathrm{o}$ cualesquiera operaciones ligadas a los bienes de la sociedad, de las que haya tenido conocimiento con ocasión del servicio del cargo, cuando la inversión o la operación hubiera sido ofrecida a la sociedad o la sociedad tuviera interés en ella, siempre que la sociedad no haya desestimado dicha inversión u operación sin mediar influencia del administrador; 3) los administradores deberán comunicar al consejo de administración cualquier situación de conflicto, directo o indirecto, que pudieran tener con el interés de la sociedad; en caso de conflicto, el administrador afectado se abstendrá de intervenir en la operación a que el conflicto se refiera; y 4) los administradores deberán comunicar la participación que tuvieran en el capital de una sociedad con el mismo, análogo o complementario género de actividad al que constituya el objeto social, así como los cargos o las funciones que en ella ejerzan, y también la realización por cuenta propia o ajena del mismo, análogo o complementario género de actividad del que constituya el objeto social. Y el artículo se detiene después en enumerar qué personas tienen la consideración de personas vinculadas a los administradores personas físicas y a los administradores personas jurídicas.

Hay una obligación en que parecen fundirse el «qué» y el «cómo» del deber: «cada uno de los administradores deberá informarse diligentemente sobre la marcha de la sociedad», dice el art. 127, segundo párrafo, de la L.S.A. La información es una obligación material, pero se insiste en que esta

\footnotetext{
${ }^{18}$ En relación con esta prohibición, y ya en el campo específico del Mercado de Valores, véase el régimen del insider o persona que dispone de información privilegiada, art. 81 LMV. Dice así el 81.1: «Se considerará información privilegiada toda información de carácter concreto que se refiera directa o indirectamente a uno o varios valores negociables o instrumentos financieros de los comprendidos dentro del ámbito de aplicación de esta Ley, o a uno o varios emisores de los citados valores negociables o instrumentos financieros, que no se haya hecho pública y que, de hacerse o haberse hecho pública, podría influir o hubiera influido de manera apreciable obre su cotización en un mercado o sistema organizado de contratación». El poseedor de información privilegiada se halla sujeto a las conseguidas prohibiciones deberes de abstención; no puede aprovechar la información para su beneficio. No puede comunicarla a un tercero (salvo en el ejercicio normal de su trabajo, profesión o cargo); y no puede recomendar a otro cesión o adquisición de los valores e instrumentos financieros.
} 
obligación ha de cumplirse diligentemente, quizás para destacar su esencialidad para la observancia del deber de diligencia.

El deber de diligencia o de cuidado se compone de un haz obligaciones más concretas: deber de atención; de promover el negocio, dirigiendo los recursos y tomando las iniciativas de acuerdo con el objeto y el interés social; el deber de profesionalidad; el deber de conocer el estatuto aplicable al propio administrador (funciones y conjunto de sus derechos y obligaciones); deber de prudencia, que impone una atención y una actitud ante los riesgos ${ }^{19}$; deber de vigilancia o supervisión; deber-derecho de estar informado; límites a la autonomía o discrecionalidad de su gestión (límites que vienen representados, además de por el marco legal, por el objeto social, las instrucciones recibidas ${ }^{20}$ de la junta, la señalada prudencia, etc.).

\section{Referencia a la responsabilidad de los administradores}

La exposición del régimen legal de la responsabilidad de los administradores en el Derecho español suele atenerse a un patrón común ${ }^{21}$. Cabe recordarlo aquí, a modo de hoja de ruta, de una manera muy sucinta:

${ }^{19}$ En cuanto a los riesgos, en relación con las sociedades cotizadas, recordar que en el obligatorio Informe Anual de Gobierno Corporativo que han de comunicar a la Comisión Nacional del Mercado de Valores, entre los contenidos mínimos que dicho documento ha de cumplir, está el relativo a los sistemas de control del riesgo (art. 116.4 d) de la Ley del Mercado de Valores).

${ }^{20} \mathrm{El}$ régimen de las instrucciones y de su fuerza vinculante en cada caso se podría construir, con todas las reservas que el recurso a la analogía aconseja, sobre la base de los artículos 254 y 255 del Código de Comercio, en sede de Comisión Mercantil. Dice el art. 255: «En lo no previsto y prescrito expresamente por el comitente, deberá el comisionista consultarle, siempre que lo permita la naturaleza del negocio [esta solución de la consulta no es, evidentemente, aplicable al administrador, dada la naturaleza de su función y el fin de su nombramiento]./ Mas si estuviere autorizado para obrar a su arbitrio, o no fuere posible la consulta [esta hipótesis ya se encuentra más próxima al desempeño del administrador, aunque en el caso del administrador no se trate de un supuesto de dificultad, sino que es precisamente lo connatural a su misión y al sentido de su existencia], hará lo que dicte la prudencia y sea más conforme al uso del comercio, cuidando el negocio como propio...» Continúa el precepto añadiendo algo que no ofrece el mismo interés para nosotros: «... En el caso de que un accidente no previsto, hiciere, a juicio del comisionista, arriesgada o perjudicial la ejecución de las instrucciones recibidas, podrá suspender el cumplimiento de la comisión. Comunicando al comitente, por el medio más rápido posible, las causas que hayan motivado su conducta».

Cabe recordar, a este respecto, la clasificación del mandato o comisión en función del grado de vinculación de las intrucciones impartidas por el mandante, en comisión imperativa, comisión indicativa y comisión facultativa. Véase L. ANGUlo RodRíGuEZ, «El Contrato de Comisión», en G. JimÉnEZ SÁNCHEZ (coord.), Derecho Mercantil, 2..$^{\circ}$ volumen, ed. Ariel,

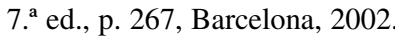

${ }^{21}$ Por todos, en cuanto manifestación de ese sistema común, véase E. BELTRÁn y A. RoJO, op. cit. 
a) En una primera a modo de parte general se recuerdan los deberes generales o fiduciarios y las obligaciones materiales concretas (entre las muchísimas que relacionábamos en la primera parte de este trabajo recordamos ahora la obligación de convocar junta general; de formular las cuentas anuales dentro del plazo legal) de solicitar, mediando causa legal, la disolución o el concurso de los administradores y se añade el cuadro de sanciones, consistentes en la separación del cargo, la exclusión del socio-administrador (esta sanción no opera en la sociedad anónima; sí, por el contrario, en la limitada, respecto al socio administrador que infrinja la prohibición de competencia -art. 98.1 LSRL-), la acción de cesación, la acción indemnizatoria y, empieza a abrirse paso -de momento en el plano doctrinal- la acción de enriquecimiento injusto contra el administrador.

b) Se examina después el ámbito subjetivo de la responsabilidad. La responsabilidad alcanza primariamente al administrador actual que lo es de derecho. No obstante, la tendencia es expansiva y por eso se estudian las condiciones bajo las cuales el régimen de la responsabilidad del administrador propio se puede extender a las siguientes otras categorías: el administrador de hecho (133.2 L.S.A.), al administrador oculto, el administrador de la sociedad dominante, el director general y los apoderados, el representante del administrador-persona jurídica y el administrador cesado. No me consta en cambio la existencia de estudios sobre cómo se modula la responsabilidad del administrador meramente aparente. Si en el caso de existir la duplicidad administrador de derecho (administrador puramente aparente)-administrador de hecho, se extiende la responsabilidad a este último, ¿significa ello que la responsabilidad se transfiere o se acumula?

c) En una tercera parte se analizan las acciones generales frente al administrador. Primero, la acción social de responsabilidad. Legitimada activamente para ejercitarla está la propia sociedad, y corresponde a la junta general de manera exclusiva la competencia para adoptar el acuerdo de presentar la demanda, aunque el punto no conste en el orden del día (art. 134.1 L.S.A.). Por de pronto, la adopción del acuerdo de emprender la acción social de responsabilidad, incluso aunque se haya tomado por sorpresa, produce un efecto fulminante: «el acuerdo de promover la acción o de transigir determinará la destitución de los administradores afectados» (art. 134.2). La mayoría de los autores se inclina por que la destitución no es un efecto esencial, sino natural y, en consecuencia, la junta, al acordar el ejercicio de la acción social de responsabilidad, puede excluirlo. Sin embargo, la jurisprudencia mantiene el automatismo de la destitución, sin posibilidad de excepción en este caso.

La L.S.A., en defensa de los intereses de los socios minoritarios, prevé en el art. 134.3, para el caso de que no haya acuerdo de la junta de exigencia de responsabilidad a los administradores, cualquiera que sea la causa de ello (falta de convocatoria de la junta por los administradores solicitada con el fin de deliberar sobre la propuesta de ejercicio de la acción, falta de pre- 
sentación de la acción en el plazo de un mes desde la adopción del acuerdo favorable a su ejercicio o acuerdo contrario a la exigencia de responsabilidad), que los accionistas que representen al menos el 5\% del capital puedan promover la demanda (acción de responsabilidad subsidiaria de primer grado). No debe confundirse esta legitimación con la que corresponde a la acción individual de responsabilidad, que se contempla en el siguiente artículo 135.

Aún contempla la L.S.A. una legitimación subsidiaria de segundo grado para el caso de que falten el impulso de la sociedad o de los socios minoritarios para presentar la demanda. Entonces se abre la posibilidad de hacerlo a los acreedores. Para este caso el art. 134.5 exige una condición adicional: «que el patrimonio social resulte insuficiente para la satisfacción» de los créditos de los acreedores.

Distinta de la acción social de responsabilidad es la acción individual, cuyo objeto es proteger, no el patrimonio de la sociedad (como cabalmente acontece de manera principal en el caso de la acción social), sino los patrimonios particulares de socios o de terceros que se relacionan con la sociedad. Es el artículo 135 L.S.A. el que se refiere a la acción individual, en los siguientes términos: «No obstante lo dispuesto en los artículos precedentes quedan a salvo las acciones de indemnización que puedan corresponder a los socios y a terceros por actos de administración que lesionen directamente los intereses de aquellos».

Los presupuestos del acción individual de responsabilidad son los siguientes: I) conducta (acción u omisión) del administrador culpablemente antijurídica (ilícita), esto es, la antijurídica ha de ser culpable, o reprochable al administrador a título de dolo o de culpa; II) producción de un daño efectivo; y III) relación de causalidad entre la conducta ilícita y el daño.

ESTEBAN VELASCO ${ }^{22}$ ha sistematizado en los grupos siguientes los supuestos reconducibles al ámbito de la acción individual: a) lesión de intereses de terceros que no están en previa relación jurídica con la sociedad («ilícitos de empresa»), donde cabe incluir los daños al medio ambiente, no retirada del mercado de productos defectuosos, actos de competencia desleal, agresiones a los derechos de propiedad industrial, etc.; b) lesión de intereses de socios por intromisión ilícita en las relaciones societarias del socio con la sociedad, donde cabe incluir la prohibición de acceso a la junta general, impedimento del ejercicio del derecho de voto, infracción del derecho de información, desconocimiento del derecho de suscripción preferente, amortización indebida de acciones, lesión del derecho de representación proporcional en el consejo, etc.; c) supuestos de intromisión lesiva en el proceso de formación de la voluntad del tercero-acreedor o del socio, que comprenden

${ }^{22}$ G. Esteban Velasco, en E. Beltrán y A. Rojo (directores). op. cit. pp 155 y ss. 
la inducción a realizar operaciones de inversión o desinversión contrarias al interés del inversor, la omisión de promover la disolución de la sociedad cuando existe causa legal que la impone (artículos 260 a 262 L.S.A.), la omisión de los deberes previstos en la Ley Concursal en caso de situación de insolvencia de la compañía.; la responsabilidad por informaciones falsas o incorrectas, especialmente de las que resultan de las cuentas y que inducen a terceros a adoptar una actitud inversora en el aumento de capital, emisión de obligaciones, etc.; y d) los supuestos de intromisión lesiva en la fase de ejecución de las relaciones existentes entre la sociedad y los terceros acreedores, donde se incluyen los vasos de contratación en situación de dificultades económicas y en caso de insolvencia (crisis ya irreversible) de la sociedad, con daño en ambos casos para los terceros acreedores que contratan con la compañía.

d) Un cuarto capítulo en el estudio de la responsabilidad de los administradores suele dedicarse al análisis de la responsabilidad en relación con ciertos sectores del ordenamiento o en determinadas situaciones especiales. Constituiría propiamente este capítulo la parte especial, donde sucesivamente se acostumbra a tratarse de la responsabilidad en caso de concurso de la compañía; la responsabilidad penal de los administradores; la responsabilidad de Derecho Administrativo y tributario (con especial atención, aunque con ello no se agota, ni mucho menos, la materia) a la responsabilidad en el ordenamiento medioambiental, en la legislación del mercado de valores (para las sociedades cotizadas, fundamentalmente) y en la legislación tributaria. Estos y otros subsectores del ordenamiento administrativo contienen enorme profusión de previsiones sobre responsabilidad de los administradores, desde las de carácter más general a las más especiales y pormenorizadas.

Algunos tratadistas de la responsabilidad de los administradores complementan su estudio con unas referencias complementarias al seguro de responsabilidad civil de los administradores y al régimen del ejercicio de las acciones de responsabilidad, donde ocupa un lugar de preferencia la cuestión de la prescripción, su plazo y su cómputo y la determinación del término inicial.

Expuesto muy sucintamente el régimen general o parte común de la responsabilidad (el derivado de la legislación societaria, en puridad), no tenemos el propósito de abordar, ni siquiera de forma embrionaria, el análisis completo de las distintas responsabilidades sectoriales arriba apuntadas. No obstante, y por pertenecer al ramo mercantil, algo añadiremos a continuación sobre la responsabilidad en la legislación del mercado de valores y en la legislación concursal.

\section{Supuestos de responsabilidad en la legislación del mercado de valores}

Las sociedades cotizadas, además de dirigirse a la consecución del propio interés social, han de respetar el interés del Mercado de Valores. Este 
interés se define según una agregación de elementos que constituyen obligaciones de conducta (fundamentalmente, comunicación de información relevante a los mercados, abstención de ciertas operaciones que produzcan ganancias diferenciales basadas en el aprovechamiento de posiciones de privilegio o movimientos artificiales de los precios, sumisión al poder de supervisión del organismo rector, etc.), cuyo cumplimiento queda garantizado, in extremis, por un régimen sancionador.

Para las sociedades cotizadas existe un régimen de responsabilidad y sanciones sectorial constituido por la legislación del Mercado de Valores. La norma de cabecera de este grupo es la Ley 24/1988, de 28 de julio, del Mercado de Valores. En su vigente redacción establece un densísimo régimen de supervisión, inspección y sanción, a cargo de la Comisión Nacional del Mercado de Valores, al que quedan sujetas, según resulta de su artículo 84, dejando al margen otros supuestos más marginales, dos grandes categorías de entidades y personas: I) las específicamente reguladas por dicha ley (profesionales o especializados en distintas actividades y servicios propios del mercado de valores), como son las sociedades rectoras de los mercados secundarios oficiales; la Sociedad de Sistemas, las entidades de contrapartida central, la Sociedad de Bolsas y las sociedades que tengan la titularidad de todas las acciones de las sociedades rectoras de los mercados secundarios oficiales, así como otros sistemas de compensación y liquidación de los mercados que se creen al amparo de la propia LMV; las empresas de servicios de inversión españolas, incluidas sus oficinas o centros tanto dentro como fuera del territorio nacional; las empresas de servicios de inversión no comunitarias que operen en España; los agentes de las entidades que presten servicios de inversión; las sociedades gestoras de los fondos de garantía de inversiones; $\mathrm{y}$, por fin, quienes no estando incluidos en los casos precedentes, ostenten la condición de miembro de algún mercado secundario oficial, o de la entidad que compense y liquide sus operaciones; y II) las personas y entidades que, no siendo profesionales o especialistas de las actividades propias de los Mercados de Valores, mantengan algún tipo de relación significativa a él vinculada (emisores, financiadores, inversores...). Se encuadran aquí los emisores de valores, las entidades de crédito y sus agentes, las empresas de servicios de inversión y las sucursales en España de entidades de crédito que operen en nuestro territorio y que estén autorizadas en otro Estado miembro de la Unión Europea («pasaporte comunitario») y, cajón de sastre amplísimo, «las restantes personas físicas o jurídicas, en cuanto puedan verse afectadas por las normas de esta Ley y de sus disposiciones de desarrollo» (art. 84.2.d).

Ya al referirse la Ley del Mercado de Valores a las Infracciones y Sanciones (artículos 95 y siguientes) contiene una serie de disposiciones de gran interés para nuestros efectos:

a) El régimen sancionador se extiende no solo a las personas físicas y entidades a las que resulten de aplicación los preceptos de la presente Ley, sino también a «quienes ostenten de hecho o de derecho cargos de adminis- 
tración o dirección de estas últimas, que infrinjan normas de ordenación o disciplina del Mercado de Valores (art. 95, primer párrafo). Y añade que a los efectos de aplicación de las disposiciones sobre infracciones y sanciones «ostentan cargos de administración o dirección... sus administradores o miembros de sus órganos colegiados de administración, así como sus Directores Generales o asimilados, entendiéndose por tales aquellas personas que, de hecho o de derecho, desarrollan en la entidad funciones de alta dirección».

El art. 99, en una larguísima relación, que concluye en el apartado «z quáter», tipifica las infracciones que se califican de muy graves; el art. 100 hace lo propio con las graves; y el breve 101 se refiere a las infracciones leves, que compendia en una fórmula general de carácter residual o negativo.

El sistema seguido para calificar las infracciones muy graves y graves es «discriminatorio». No todas las personas o entidades pueden cometer todo tipo de infracción. Hay infracciones solo al alcance de los «especialistas» (y aún dentro de estos, hay que discernir por subcategorías; así, las infracciones de las sociedades rectoras -p. ej, art. 100 a), b), c)-; las de las empresas de servicios de inversión -art. 99 e), e bis), e ter)-; de los miembros de los mercados secundarios oficiales o de los sistemas multilaterales de negociación -99 f)-, etc.). Pero también están (y son las que interesan ahora) las infracciones establecidas para la categoría de personas y entidades no especialistas o no cualificados. Así, para las entidades emisoras: la colocación de ciertas emisiones sin cumplir el requisito de intervención de entidad autorizada, sin atenerse a las condiciones básicas publicitadas, omitiendo datos relevantes o incluyendo inexactitudes, falsedades o datos que induzcan a engaño en la citada actividad publicitaria (art. $99 \mathrm{ll}$ bis); el suministro a la Comisión Nacional del Mercado de Valores de la información financiera regulada con datos inexactos o no veraces, o de información engañosa o que omita maliciosamente aspectos o datos relevantes (art. $99 \mathrm{~m}$ ) in fine); la realización de ofertas públicas de venta o suscripción o la admisión a negociación sin cumplir los requisitos legales sustanciales, la colocación de la emisión sin atenerse a las condiciones básicas establecidas en el folleto, en caso de que deba elaborarse dicho documento (art. 99 n); la inobservancia del deber de información legal cuando exista un interés de ocultación o negligencia grave, atendiendo a la relevancia de la comunicación no realizada y a la demora en que se hubiese incurrido (art. 99 p); la realización de actos fraudulentos o la utilización de personas físicas o jurídicas interpuestas con la finalidad de conseguir un resultado cuya obtención directa implicaría, al menos, la comisión de una infracción grave, así como la intervención o realización de operaciones sobre valores que implique simulación de las transferencias de la titularidad de estos (99 s); la adquisición de una participación significativa o su aumento o reducción incumpliendo las condiciones exigidas por la LMV (art. $99 \mathrm{u}$ ). Si las hasta ahora referidas son algunas de las 
infracciones muy graves, entre las simplemente graves seleccionamos una breve muestra: falta de comunicación de hecho relevante (100 a bis); la falta de remisión en plazo a la Comisión Nacional del Mercado de Valores de cuantos documentos o informaciones deba remitírsele o esta requiera en el ejercicio de sus funciones, siempre que la citada Comisión hubiera recordado por escrito la obligación o reiterado el requerimiento (100 b); la falta de elaboración o de publicación del informe anual de gobierno corporativo a que se refiere el art. 116 de la LMV, o la existencia en dicho informe de omisiones o datos falsos o engañosos; el incumplimiento... y el carecer las entidades emisoras de valores admitidos a cotización en mercados secundarios oficiales de un Comité de Auditoría, en los términos establecidos en la disposición adicional decimoctava de la LMV (100 b bis); la inexistencia de la página web prevista en el apartado 2 del artículo 117 LMV o la falta de publicación en ella de la información señalada en dicho artículo y en otros preceptos de la Ley o de su normas de desarrollo (100 m); el incumplimiento por las entidades emisoras con valores admitidos a negociación en los mercados secundarios de valores de sus obligaciones respecto del sistema de registro de dichos valores (100 u); añade el art. $100 \mathrm{x}$ bis) el incumplimiento de la obligación de comunicación a la CNMV de operaciones sospechosas de constituir abuso de mercado, establecida en el artículo 83 quáter de esta Ley (y cabe recordar aquí que este último artículo, en su apartado 1, recoge la obligación de comunicar operaciones sospechosas en los siguientes términos: «Las entidades que efectúen operaciones con instrumentos financieros deberán avisar a la Comisión Nacional del Mercado de Valores, con la mayor celeridad posible, cuando consideren que existen indicios razonables para sospechar que una operación utiliza información privilegiada o constituye una práctica que falsea la libre formación de los precios»); la falta de publicación o de remisión a la CNMV de la información y documentación que haya de publicarse o enviarse a aquella, como consecuencia de actuaciones que obliguen a la presentación de una oferta pública de adquisición de valores, en el transcurso de esta o una vez finalizada, cuando no constituya infracción muy grave $(100 \mathrm{z})$; la publicación o el suministro de información o documentación relativas a una oferta pública de adquisición con omisión de datos o con inclusión de inexactitudes, falsedades o datos que induzcan a engaño, cuando no fuera infracción muy grave (100 z bis); la falta de inclusión en el informe de gestión de las sociedades cotizadas de la información exigida por el artículo 116 de esta Ley o la existencia de omisiones o datos falsos o engañosos).

Hay una infracción que, aunque se refiera a la categoría que hemos denominado de las entidades cualificadas o especialistas, interesa retener, por hacer referencia particularmente al ejercicio de las funciones de administración. Dice así el art. $100 \mathrm{~s}$ que constituye infracción grave «la efectiva administración o dirección de las entidades a que se refieren las letras a, b, c y e del artículo 84.1 de esta Ley por personas que no ejerzan de derecho en las 
mismas un cargo de dicha naturaleza». Obviamente, se está refiriendo aquí la norma no tanto a un caso de intrusismo o usurpación de funciones cuanto al supuesto consentido de «administrador en la sombra».

\section{Responsabilidad de los administradores en el procedimiento con- cursal. La sección de calificación del concurso}

La Ley 22/2003, de 9 de julio, Concursal dedica los artículos 163 a 173 a la calificación del concurso. La calificación del concurso constituye, como es sabido, la sección sexta de la tramitación del procedimiento, sección que no es de existencia necesaria en todo caso, pues solo procederá su formación o apertura cuando (art. 163.1) concurra alguna de estas dos circunstancias: I) que se apruebe judicialmente un convenio en el que se establezca, para todos los acreedores o para los de una o varias clases, una quita superior a un tercio del importe de sus créditos o una espera superior a tres años; y II) que se abra la fase de liquidación.

Las calificaciones hoy posibles, de acuerdo con la citada Ley Concursal, se han reducido a dos: culpable y fortuito. Se abandona la posibilidad de la «quiebra fraudulenta» que figuraba en el Código de Comercio de 1885: «el concurso se calificará como fortuito o como culpable. La calificación no vinculará a los jueces y tribunales del orden jurisdiccional penal que, en su caso, entiendan de actuaciones del deudor que pudieran ser constitutivas de delito» (163.2). La calificación se hace en sentencia (art. 172) y en el procedimiento seguido para efectuar tal declaración judicial tiene especial importancia el informe de la administración concursal, que ha de presentarse al juez, y que ha de ser razonado, documentado, versar sobre los hechos relevantes para la calificación del concurso y contener una propuesta de resolución $(169.1)^{23}$.

${ }^{23}$ La Sentencia del Tribunal Supremo, de 22 de abril de 2010, que es la primera sobre calificación concursal, utiliza la vía de responsabilidad objetiva o cuasiobjetiva y declara, entre otras cuestiones, que se habrán de aportar con el informe los documentos en que se funda la propuesta de resolución, pero ello no es necesario en cuanto a los documentos que obran en las restantes Secciones del Concurso, respecto de los que no se requiere la aportación física, bastando que en el informe se haga la oportuna remisión: «FUNDAMENTOS DE DERECHO.

PRIMERO.- En los autos de concurso voluntario número 158 de 2005 del Juzgado de 1 Instancia número 1 de Murcia, en los que figura como concursada la entidad mercantil BIOFERMA MURCIA, S.A., CIF A- 73039752, dedicada a la fabricación de productos farmacéuticos y con domicilio en el Polígono Industrial Las Salinas, Parcela 10, C.P. 30.840 de Alhama de Murcia, se dictó auto el 7 de junio de 2006 en el que, al no haberse aprobado en la Junta de acreedores celebrada el día 6 anterior la propuesta de convenio, se acordaba entre otros pronunciamientos, la apertura de la fase de liquidación, y como consecuencia legal -art. 163.1.2. ${ }^{\circ}$ de la Ley Concursal 22/2003, de 9 de julio-, también la de la Sección de Calificación. En esta Sección se emitió Informe por los administradores concursales el 20 de septiembre de 2006 en el que solicitan del Juzgado que se declare: 1. El concurso de la entidad 
Cuando la propuesta fuera de calificación culpable, el informe expresará la identidad de las personas a las que deba afectar la calificación y de las que hayan de ser consideradas cómplices (el art. 166 especifica quiénes merecen

Bioferma Murcia, S.A. como culpable; 2. Que las personas afectadas por la calificación se refiere a los miembros del consejo de administración D..., en su calidad de consejero apoderado. Y se condene: a) A estar y pasar por las anteriores declaraciones, b) A los miembros del consejo de administración mencionados a la inhabilitación a que se refiere el apartado $2 .^{\circ}$ del número 2 del art. 172 de la Ley Concursal. C) A satisfacer a los acreedores en las cantidades expresadas en el hecho segundo del informe y en relación con lo preceptuado en el apartado $3 .^{\circ}$ del art. 172 de la Ley Concursal; y, d) Al pago de las costas del incidente en caso de oposición. El 28 de septiembre de 2006 el Ministerio Fiscal emitió dictamen en el sentido de que aceptaba y compartía todas las razones que avalan el informe de la administración concursal, calificando por ello el concurso de culpable. El Juzgado, en cumplimiento de lo establecido en el art. 170.2 LC, dio audiencia a la entidad deudora Bioferma por plazo de diez días, la cual presentó el 3 de noviembre de 2006 escrito de «oposición a la calificación de culpable solicitada, oposición que se articula en la persona de sus administradores Dn... y Dn..., contra quienes se dirige esta pieza de calificación, debiendo entenderse realizadas las manifestaciones en interés de la deudora, y en su propio interés» (f. 382 de la Sección Sexta). Por providencia de 9 de noviembre de 2006, el Juzgado acordó formar la pieza separada de incidente concursal que se registró con el número 340 de 2006.

El incidente se resolvió en primera instancia por Sentencia del Juzgado de 19 de febrero de 2007 en cuyo fallo acuerda que "estimando parcialmente la demanda de oposición a la calificación del concurso voluntario de BIOFERMA MURCIA, S.A., seguida con el número 340/06: -Declaro CULPABLE el concurso voluntario de BIOFERMA MURCIA, S.A. tramitado con el n. ${ }^{\circ}$ 158/05. - Declaro afectados por la declaración del concurso como culpable a los administradores sociales Don... [sic], (consejero delegado ejecutivo) y Don... (consejero apoderado). - Condeno a los Sres... un período de inhabilitación para administrar bienes ajenos así como para representar o administrar a cualquier persona durante un periodo de dos años desde la firmeza de la presente sentencia. - Debo condenar y condeno a los Srs... a la pérdida de cualquier derecho que tuvieran como acreedores del concurso o de la masa y a devolver los bienes que hubieran recibido de la masa activa. - Y que además, condeno al Sr... [sic] a que pague totalmente el importe de los créditos que no perciban en la liquidación de la masa activa los acreedores concursales".

La anterior resolución fue confirmada por la Sentencia de la Sección Cuarta de la Audiencia Provincial de Murcia el 31 de julio de 2008, en el Rollo número 230 de 2007, en la que se desestima el recurso de apelación formulado por el Procurador Sr. Rentero Jover en nombre y representación de la mercantil BIOFERMA MURCIA, S.A.

Contra dicha Sentencia se interpuso por BIOFERMA MURCIA S.A. recursos extraordinarios por infracción procesal y de casación que fueron admitidos por Auto de esta Sala Primera de 8 de septiembre de 2009.

\section{RECURSO EXTRAORDINARIO POR INFRACCIÓN PROCESAL.}

Se articula en seis motivos que se examinan seguidamente.

SEGUNDO.- En el primer motivo del recurso, al amparo del art. 469.1.3. ${ }^{\circ}$ LEC, se denuncia infracción de los artículos 170, 171 y 194 de la Ley Concursal.

En el motivo se sostiene, en síntesis, que en la tramitación del incidente concursal no se observó la normativa legal de los arts. 170 y 171 de la Ley Concursal, toda vez que el Juzgado, tras tener por presentada la oposición de la entidad concursada, dio nuevo traslado a la Administración concursal para que en el plazo de diez «la contestase, cuya infracción se 
tal consideración). Justificando la causa, así como la determinación de los daños y perjuicios que, en su caso, se hayan causado por las personas anteriores (169.1, in fine). Una vez presentado el informe de la administración

denunció estérilmente por la parte mediante recurso de reposición y en el acto de la vista celebrada el 13 de febrero de 2007, y, en contra de lo que argumenta la resolución aquí recurrida, se tradujo en indefensión en los aspectos relativos a la carga de la prueba e inversión de posiciones procesales en el acto de juicio, al dársele a la entidad concursada opositora un trato de demandante, teniendo que actuar en primer lugar, mientras que la Administración concursal tuvo la oportunidad de cerrar con sus alegaciones, y lo que es peor, dándole la oportunidad de interrogar en último lugar, de practicar su prueba en último lugar, en definitiva de ser demandados de la calificación que ellos mismos solicitan».

Con carácter prioritario debe señalarse que en los autos del incidente concursal no hay constancia de haberse cumplido el requisito del recurso de reposición contra la providencia de 9 de noviembre de 2006 a que se alude en el motivo, si bien debe tenerse por acreditada, a los efectos de la exigencia formal de los arts. 459, in fine, y 469.2 LEC, la denuncia oportuna de la infracción, por haberse reconocido la realidad de la misma, sin contradicción alguna, por la Sentencia de la Audiencia Provincial.

Se denuncia en el motivo que la sentencia impugnada conculca el contenido de los artículos 170 y 171 de la Ley Concursal, y ello no es así porque dicha resolución explícitamente reconoce que la tramitación de la Sección de Calificación seguida en primera instancia no fue correcta al haberse dado a la Administración Concursal un trámite de contestación al escrito de oposición de la entidad concursada que no está previsto en la ley, y, a lo que cabe añadir, no exigible por el principio de contradicción.

Y si bien no atribuye al defecto procesal consecuencia anulatoria, ello responde, por un lado, a que no le da ningún valor a la "contestación" -"en modo alguno es determinante, ni tiene incidencia relevante para resolver las cuestiones planteadas"- y resuelve el asunto exclusivamente con base en el Informe de los Administradores Concursales y oposición de la entidad concursada, y, por otro lado, a que estima que dicho defecto no ha causado indefensión material a la parte recurrente por lo que no procede la nulidad de actuaciones.

En cuanto al primer aspecto resulta evidente que si la sentencia recurrida priva de valor o eficacia a una actuación procesal ningún perjuicio se puede derivar de ello para la parte que solicitó la invalidez.

Declarar la nulidad de actuaciones para reponerlas a un momento procesal anterior no supondría ningún efecto útil para el proceso, afectaría a la regla de la economía procesal, no sería conforme al principio de conservación de actos procesales (arts. 230 LEC y 243.1 LOPJ), e incluso resultaría contraria a la propia conducta endoprocesal de la parte recurrente, la cual, en el escrito de fecha 3 de enero de 2007 (f. 313 de los autos del incidente concursal), claramente solicitaba que no se admitiera a trámite el escrito de contestación de la Administración concursal, pero «sin necesidad de modificar la fecha de la vista oral para el próximo 23 de enero de 2007, habida cuenta de que no existe ningún ánimo dilatorio por esta parte, y de que la correcta tramitación de la pieza de calificación prevé que tras el escrito de alegaciones presentado por la concursada, se convoque a dicha vista».

Por otro lado, por lo que atañe al segundo aspecto relativo a la actuación de las partes en el acto de la vista no se ha producido indefensión, tal y como sienta la resolución recurrida. Para que una irregularidad o defecto procesal determine la nulidad precisa de un declaración explícita de la ley o ha de producir indefensión (arts. 225. 3..$^{\circ}$, en cuanto a las normas del procedimiento; 459 y $4691.3 .^{\circ}$ y 2 , LEC y $238.3 .^{\circ}$ y 240.1 LOPJ), la cual habrá de ser real y efectiva -indefensión material-. En el caso no ha habido indefensión material. No la hay 
concursal, se concederá plazo de diez días al Ministerio Fiscal para que emita dictamen sobre lo mismo. Pero este dictamen no es imprescindible, pues la ley contempla el caso de que no se emita, en cuyo caso seguirá el proce-

en la perspectiva de la carga de la prueba, pues no consta apreciación alguna en la sentencia recurrida de la que quepa deducir que la actuación de las partes en el acto de la vista del incidente concursal ha incidido en la distribución de la carga de la prueba, ni, lo que es más relevante, en la atribución de las consecuencias desfavorables de la falta de prueba, cuya apreciación debe entenderse sin perjuicio de lo que se razonará más adelante sobre la adecuada aplicación del art. 217 LEC con abstracción de si se actuó en una u otra postura o del momento procesal. Tampoco hay asomo de indefensión en relación con la práctica de las pruebas, ni en cuanto al orden de los informes, porque no hay la mínima constancia de que se le privara a la entidad concursada de contradecir las alegaciones y planteamientos de la Administración concursal, habiendo podido alegar y probar sus causas de oposición con cabal plenitud y sin afectación alguna al ejercicio de su derecho de defensa.

Por todo ello se desestima el motivo.

TERCERO.- En el motivo segundo, al amparo de lo establecido en el art. 469.1.3. ${ }^{\circ}$ LEC, se alega infracción de las normas reguladoras de la sentencia por infracción del art. 270 LEC.

El motivo se resume en que se admitió como prueba documental el contenido de las actuaciones de las demás Secciones del Concurso.

El motivo se desestima, con independencia de la deficiente indicación del enunciado, por las razones siguientes.

El art. 169 de la Ley Concursal dispone en relación con el informe de la administración concursal que habrá de ser razonado y documentado sobre los hechos relevantes para la calificación del concurso. La disposición legal debe entenderse en el sentido de que se habrán de aportar con el informe los documentos en que se funda la propuesta de resolución, pero ello no es necesario en cuanto a los documentos que obran en las restantes Secciones del Concurso, respecto de los que no se requiere la aportación física, bastando que en el informe se haga la oportuna remisión. Por lo demás, la prueba documental fue admitida, la parte recurrente no podía desconocerla dado que obraba en las actuaciones, y es de absoluta lógica que la Audiencia Provincial reclame las restantes actuaciones en que obran documentos para cumplir la función de valoración probatoria en segunda instancia. La exigencia de que se deban reproducir, para acompañar con el informe de los administradores, documentos que obran en otras secciones no es razonable, ni es conforme a la economía procesal al suponer un derroche de tiempo y coste económico absolutamente innecesario, sin que resulte afectado en modo alguno el derecho de defensa.

CUARTO.- En el motivo tercero (por error se repite como segundo) se acusa, al amparo del art. 469. 1. 2. ${ }^{\circ}$ de la LEC, infracción de las normas procesales reguladoras de la sentencia. En el cuerpo del motivo se alega incongruencia por contradicción entre los fundamentos de derecho segundo y cuarto de la resolución recurrida, e incongruencia extra petita porque no hubo petición de la causa de culpabilidad del art. 164.1 -cláusula general- LC, ni tal petición se incluía de forma tácita en el informe de los administradores.

El motivo se desestima porque carece de consistencia.

En cuanto al primer aspecto ni concurre el defecto, ni de concurrir sería de incongruencia, sino de motivación deficiente por incoherencia formal. Y no concurre porque lo que la Sentencia dice (pgs. 5 y 10 a 12) es que existen unos pronunciamientos que no pueden ser adoptados si no hay petición de la Administración Concursal o del Ministerio Fiscal, y otros que son de apreciación de oficio y aplicación automática por el Juez del Concurso, y en esto 


\section{dimiento su curso y se entenderá que no hay oposición a la propuesta de cali- ficación formulada por la administración concursal.}

no hay ninguna contradicción, sin perjuicio de señalar, aunque no hay cuestión en el presente recurso, que la adopción de oficio de las medidas requiere inexcusablemente la previa audiencia de las personas afectadas por respeto al principio constitucional de contradicción procesal.

En cuanto al segundo aspecto, relativo a la alegación de incongruencia extra petita por alteración de la causa petendi, debe señalarse, por un lado, que evidentemente se aprecia una inclusión tácita (rectius implícita) en el Informe de la Administración Concursal que se revela singularmente en el apartado F), en cuanto se refiere al hecho de la disposición de la cantidad de 1.750.000 euros [que se extrajeron de la tesorería de la empresa sin contrapartida] como «determinante de la agravación» de la insolvencia, lo que encaja plenamente en el precepto del art. 164.1 LC; y debe resaltarse, por otro lado, que para la concurrencia del supuesto genérico de culpabilidad del concurso no resulta ineludible, otra cosa es que sea conveniente, que la calificación del Informe de la Administración Concursal o del dictamen del Ministerio Fiscal contenga una mención explícita y formal del concreto precepto legal que cobija el supuesto normativo, siendo suficiente que en la fundamentación consten los hechos relevantes para la adecuada calificación y que claramente resulten expresivos de la causa correspondiente, como sucede en el caso.

QUINTO.- En el motivo cuarto se denuncia, al amparo del art. 469.1.2. ${ }^{\circ}$ de la LEC, infracción de las normas relativas a la valoración de la prueba.

Se impugna la valoración de las pruebas pericial y documental fundamentalmente en relación con la apreciación de la resolución recurrida de que las transferencias realizadas por importe de 1.500 .000 euros y 250.000 euros no tienen contraprestación alguna. Asimismo se denuncia la infracción de los arts. 335, 343 y 348 LEC al atribuir parcialidad al perito Dn..., por el mero hecho de haber sido aportada la pericial por la parte.

El motivo se desestima por tres razones.

La primera razón consiste en que la valoración probatoria es una función que corresponde a los Tribunales que conocen en primera y segunda instancia, a los de esta en la misma medida que a los de aquélla dentro del ámbito devolutivo, y queda fuera del conocimiento de este Tribunal en los recursos extraordinarios.

La segunda razón reside en que si bien excepcionalmente cabe un control por este Tribunal de la alegación de un error en la valoración probatoria, para tal verificación se requiere que pueda existir un error fáctico patente, arbitrariedad o irracionalidad, con conculcación del art. $24 \mathrm{CE}$, y se plantee la denuncia por el cauce del art. 469.1.4. ${ }^{\circ}$ LEC. Y nada de ello sucede en el caso, pues ni siquiera las normas probatorias aludidas contienen reglas de prueba legal o tasada que hubieran podido determinar una posible arbitrariedad.

Y finalmente, el Tribunal no atribuye al perito que haya sido parcial, sino que, en ejercicio de su función soberana de valoración de la prueba, considera más convincente, y con mayor objetividad, el informe de los administradores concursales que el pericial aportado por la parte, sin que quepa desconocer, además, que el informe de los administradores no es un elenco de meras manifestaciones, sino que tiene soporte en la documental que explícitamente reseña.

SEXTO.- Los motivos quinto y sexto se alegan conjuntamente, y en los mismos se denuncia, al amparo del art. 469.1.2. ${ }^{\circ}$ LEC, infracción de las normas reguladoras de la sentencia, y concretamente del art. 218.2 LEC que establece que las sentencias deberán estar motivadas. 
La calificación del concurso como culpable no se deja al buen criterio del juez, ni a la mera opinión de los administradores concursales. Pero tampoco lo contrario. La ley define los supuestos de concurso culpable, pero en ocasiones lo hace en términos tan abiertos que deja un amplio margen de apreciación al informe de los administradores concursales y a la decisión final del juzgador. El sistema de definición del concurso culpable (el del fortuito es menos problemática, pues es fortuito el concurso no culpable) se

En el cuerpo del motivo se acumulan diversas alegaciones relativas a: (a) que no se han valorado las pruebas pericial, testifical y documental; (b) falta de prueba de que la disposición de 1.750.000 euros fue la causa de la insolvencia de la sociedad; y (c) que la insolvencia anterior a la posición de D... y D... como administradores de la sociedad simplemente se menciona pero no se valora y, sin embargo, es una alegación esencial en la medida en que por sí misma es relevante para verificar la causa del concurso, y la gradación en su caso de la responsabilidad.

Los motivos deben desestimarse por las razones siguientes:

La primera alegación (a) carece de base alguna pues la valoración de la prueba se motiva con amplitud y claridad en el fundamente tercero de la resolución recurrida, el cual no se limita a aceptar los razonamientos segundo y tercero de la resolución de primera instancia (válida como motivación por remisión), sino que incluso expone diversas razones en orden a la apreciación de los datos fácticos relevantes que explican la raíz causal del fallo -ratio decidendi-. Otra cosa diferente es que la parte no esté de acuerdo con la valoración de la prueba que se efectúa en dicha resolución, pero ello no tiene nada que ver con la motivación. Por otro lado debe señalarse que la motivación no exige al Tribunal explicar el porqué de atribuir una mayor o menor convicción a cada uno de los elementos de prueba obrantes en las actuaciones.

La segunda alegación (b) no se ajusta a lo que dice la resolución recurrida, dado que el último párrafo del fundamento de derecho tercero de la misma claramente se refiere a que la disposición de tesorería por importe de 1.750 .000 euros «agravó» el estado de insolvencia de la entidad, y, por otro lado, lo que es más relevante, no resulta incardinable en los motivos, porque referida la denuncia formulada en los mismos a la motivación, el hipotético error en la valoración probatoria no supone falta de argumentación, sino otro tipo defecto, para cuya verificación por este Tribunal procedería un planteamiento procesal diferente.

Finalmente, en cuanto a la tercera alegación (c) carece de trascendencia para el pleito. Los hechos relevantes para la calificación del concurso como culpable (causas del art. 164.1 y $2.1 .^{\circ}$ y $2 .^{\circ}$ LC) se produjeron bajo la administración social de D... y D..., y no resulta cuestionable, sin hacer supuesto de la cuestión, que la salida de la tesorería sin contrapartida en los meses de enero y febrero de 2005 de cantidades por importe total de 1.750 .000 euros produjo el estrangulamiento económico de la empresa. Por último, entrar aquí ahora a discurrir sobre responsabilidades no resulta oportuno dada la naturaleza y función del recurso que se examina, y tanto más que los administradores afectados no han recurrido». D. Jesús Corbal Fernández.

Una vez unido el informe de la administración concursal, se dará traslado del contenido de la sección sexta al Ministerio Fiscal para que emita dictamen en el plazo de diez días. El juez, atendidas las circunstancias, podrá acordar la prórroga de dicho plazo por un máximo de diez días más. Si el Ministerio Fiscal no emitiera dictamen en ese plazo, seguirá su curso el proceso y se entenderá que no se opone a la propuesta de calificación (art. 169.2). 
construye sobre la base de dos fórmulas ${ }^{24}$ : a) por una parte, se considera culpable el concurso en que medie dolo o culpa grave del deudor (art. 164.1), añadiendo el art. 165 tres supuestos de presunción iuris tantum de la existencia de dolo o culpa grave (lo que no impide que estos, el dolo y la negligencia grave) puedan revestir otras formas, pero entonces deberán acreditarse. Y junto con la anterior fórmula general se añade una relación de supuestos concretos (lista de casos) de concurso culpable. Analizaremos seguidamente, de manera sumaria, estas dos fórmulas y, en vista de que se pronuncian con frecuencia con términos laxos, anotaremos algunas resoluciones judiciales ${ }^{25}$ que, como precedentes de autoridad, pueden ayudar en la tarea de precisar el significado de las fórmulas legales.

a) Fórmula abstracta de definición del supuesto general. Dispone el art. 164.1 que «el concurso se calificará como culpable cuando en la generación o agravación del estado de insolvencia hubiera mediado dolo o culpa grave del deudor o, si los tuviere, de sus representantes legales y, en caso de persona jurídica, de sus administradores o liquidadores, de derecho o de hecho». Se presume la existencia de dolo o culpa grave, añade el art. 165, salvo prueba en contrario, cuando el deudor o, en su caso, sus representantes legales, administradores o liquidadores, se encontraran en alguno de los tres siguientes supuestos: I) hubieran incumplido el deber de solicitar la declaración del concurso; II) hubieran incumplido el deber de colaboración con el juez del concurso y la administración concursal, no les hubieran facilitado la información necesaria o conveniente para el interés del concurso o no hubiesen asistido, por sí o por medio de apoderado, a la junta de acreedores; y III) si el deudor obligado legalmente a la llevanza de contabilidad, no

${ }^{24}$ Declara la Sentencia de la Audiencia Provincial de Barcelona, de 19 de marzo de 2007 (Ponente D. Ignacio Sancho Gargallo): «FUNDAMENTOS DE DERECHO. Séptimo... Para juzgar sobre la calificación culpable o fortuita del concurso, la Ley centra su atención en determinar cuándo puede calificarse culpable el concurso, para lo que atiende a un triple criterio: en primer lugar, a una definición legal, que considera culpable el concurso cuando la insolvencia se hubiera generado o agravado mediando dolo o culpa grave del deudor, o, en el caso de las personas jurídicas, de sus administradores o liquidadores (art. 164.1 LC); en segundo lugar, una tipificación de supuestos que al margen de la concurrencia o no de la culpa merecen por sí mismos la calificación culpable (art. 164.2 LC); y, en tercer lugar, tres casos en los que se presume iuris tantum el dolo o la culpa grave, y consiguientemente admiten la prueba en contrario para eludir la calificación culpable del concurso (art. 165 LC)...».

${ }^{25}$ Las resoluciones judiciales las hemos obtenido de F. GómEZ, MARTín, Calificación del Concurso de Acreedores. El autor amablemente nos ha cedido este trabajo, del que no me consta edición, Sevilla, 2009, revisado en mayo 2010. Su consulta resulta imprescindible. Pueden verse también A. BARó CASAls, Jurisprudencia Concursal Sistematizada (2006, 2007, 2008 y 2009), accesible en Internet, donde aparece ordenada, artículo a artículo de la Ley Concursal, los pronunciamientos judiciales más significativos, y J. A. GARCíA-CRUCES, «El problema de la represión de la conducta del deudor», La Reforma de la Legislación Concursal, Jornadas, Madrid, 6 a 10 de mayo de 2002, ed. Marcial Pons, Ediciones Jurídicas y Sociales, S.A., Madrid, 2003. 
hubiera formulado las cuentas anuales, no las hubiera sometido a auditoría, debiendo hacerlo, o, una vez aprobadas, no las hubiera depositado ${ }^{26}$ en el

${ }^{26}$ Juzgado de lo Mercantil N. ${ }^{\circ} 1$ de Madrid, de fecha 16 de enero de 2007, que volveremos a citar «FUNDAMENTOS DE DERECHO. OCTAVO.- 1. Por último, alude la Administración concursal a la falta de depósito de las Cuentas Anuales de Núcleos de Organización y Administración, S.A. durante los ejercicios 2002 y 2003. No se pone en duda por ninguno de los intervinientes que las cosas fueron así desde 1999. La evidencia de tal hecho resulta del cierre de la hoja registral acordada por el Registrador Mercantil en aplicación del artículo 378 RRM. De acuerdo con el artículo $165.3 .^{\circ} \mathrm{LC}$ «se presume la existencia de dolo o culpa grave, salvo prueba en contrario (...):(...) 3..$^{\circ} \mathrm{Si}$ el deudor obligado legalmente a la llevanza de contabilidad, no hubiera formulado las cuentas anuales, no las hubiera sometido a auditoría, debiendo hacerlo, o, una vez aprobadas, no las hubiera depositado en el Registro Mercantil en alguno de los tres últimos ejercicios anteriores a la declaración de concurso». Como hemos puesto de relieve desde el año 1999 hasta el año 2003 las Cuentas Anuales de la entidad Núcleos de Organización y Administración, S.A. no fueron ni confeccionadas ni depositadas. La Administración concursal ciñe dicha responsabilidad a los tres años anteriores a la declaración de concurso (artículo 165.3. ${ }^{\circ}$ LC). Debemos partir de que el artículo 165 LC presume dolo o culpa grave en la causación o agravación de la insolvencia cuando concurren algunos de los comportamientos en el mismo relacionados, presunción que lo es salvo prueba en contrario. Ello supone una suerte de inversión en la carga de la prueba, esto es, que aquel a quien se imputa la conducta presuntiva puede destruirla mediante su actividad probatoria. Caso de no realizar actividad probatoria al respecto o no tener virtualidad para destruir la presunción deberá considerarse que la conducta tipificada conlleva la declaración del concurso como culpable.

2. La conducta tipificada en el artículo $165.3 .^{\circ}$ LC consiste en que el deudor obligado a ello bien no haya formulado las Cuentas Anuales, bien no las haya sometido a auditoría, debiendo hacerlo, bien no las haya depositado en el Registro Mercantil una vez aprobadas. Y ello con alcance a los tres últimos ejercicios anteriores a la declaración de concurso. No hay duda que la responsabilidad de confeccionar y depositar en el Registro Mercantil las Cuentas Anuales de una sociedad corresponde a los administradores sociales (artículos 171 LSA y 84 LSRL). El administrador social en los ejercicios en que debieron ser confeccionadas y depositadas las Cuentas Anuales de Núcleos de Organización y Administración, S.A. correspondientes a los ejercicio 2002 y 2003 fue la entidad ACUMEN BV. Esta fue designada administradora desde el día 13 de julio de 2001 hasta el mes de marzo de 2004 (interrogatorio de D. Narciso). Durante tal período, ACUMEN BV designó, ex artículo 143 RR, a D. Luis Andrés como apoderado en España y en su virtud gestionaba la entidad Núcleos de Organización y Administración, S.A. Precisamente dicho demandado afirmó en el acto de la vista que era consciente de que las Cuentas Anuales no se confeccionaban, y atribuyó tal falta a problemas de auditoría, aunque no concreto cuáles. En el escrito de oposición a la calificación del concurso como culpable, tanto D. Luis Andrés como ACUMEN $\mathrm{BV}$ afirman en relación con dicha causa que lo relevante no es que durante el período aludido se dejaran de confeccionar y depositar las Cuentas Anuales -lo que, como hemos dicho, se reconoce- sino que en el momento de declarase el concurso tal defecto había sido subsanado -lo que tampoco nadie discute-. No puede admitirse tal tesis. Habida cuenta del fin que la Ley atribuye a las Cuentas Anuales tanto por la información interna que proporcionan como la externa, es obvio que en la causación o agravamiento de la insolvencia tiene importancia relevante la omisión de la confección y depósito de las Cuentas Anuales en el momento en que debió llevarse a cabo. Por un lado, porque su conocimiento pudo alertar al órgano de administración y aconsejar la adopción de ciertas decisiones (vid. p.e. artícu- 
Registro Mercantil en alguno de los tres últimos ejercicios anteriores a la declaración de concurso.

b) Fórmula complementaria de relación o listado de casos singulares de concurso culpable (art. 164.2). En todo caso el concurso se calificará como culpable cuando concurra cualquiera de los siguientes supuestos: I) cuando el deudor legalmente obligado a la llevanza de contabilidad incumpliera «sustancialmente» esta obligación ${ }^{27}$, llevara doble contabili-

los 262 LSA y 105 LSRL); y por otro, porque los proveedores y los clientes hubieran podido a su vista adoptar determinadas conductas que la ignorancia de tales Cuentas no les permitió. De ahí que la conducta relevante sea la omisión de la confección y depósito tempestivo de las Cuentas Anuales, y sea irrelevante el que, en el momento de la declaración del concurso se hubiera subsanado el defecto. Sin embargo, no podemos olvidar que nos encontramos ante una presunción iuris tantum de culpabilidad. Si el administrador que omitió su obligación de confeccionar y depositar las Cuentas Anuales acreditase debidamente que tal omisión ha sido irrelevante a los efectos de generar o agravar el estado de insolvencia de la concursada, tal omisión debería considerarse irrelevante a los efectos de la declaración de culpabilidad. Pero este no ha sido el caso, por lo que el concurso merece el calificativo de culpable por tal causa». D. Antoni Frigola i Riera.

${ }^{27}$ La Sentencia del Juzgado de lo Mercantil N. ${ }^{\circ} 1$ de Alicante, de fecha 31 de julio de dos mil ocho, califica de culpable el concurso por incumplimiento sustancial de la llevanza contable: «FUNDAMENTOS JURÍDICOS.

Primero.- Planteamiento.

1. Por la administración concursal se solicita la calificación como culpable del concurso de la entidad JOSIMASA SL, que se tramita coordinadamente con el de la sociedades TRUDO SL y DISEÑO Y LOGISTICA DEL CALZADO SL (con igual numero de autos pero bis y ter, respectivamente, con el que comparten gran parte de la problemática, por lo que idéntica ha de ser la respuesta) por estar incursa en los supuestos del art. 164.2.1 LC, indicando como persona afectada por la calificación al que fue su administrador D... la inhabilitación de 4 años.

2. El Ministerio Fiscal en su informe se adhiere a los mismos motivos y peticiones indicados por la administración concursal.

3. La mercantil concursada y la persona afectada se oponen, en extracto, negando la concurrencia de las causas aducidas por la admón. concursal y Ministerio Fiscal.

4. Las alegaciones fácticas y pretensiones de las partes delimitan el alcance del pronunciamiento judicial, sin que pueda el Juzgador apreciar ex oficio supuestos de culpabilidad no invocados y cuyo sustrato fáctico no haya sido debatido, por exigencia del principio de defensa y de contradicción (Art. 24 CE y 218 LEC) precisando la sentencia de calificación una previa petición fundada de la admón. concursal o del Ministerio Fiscal, que constriñen los pronunciamientos condenatorios, a salvo el de inhabilitación, en el que solo viene limitada su extensión al considerarse pena civil ex lege en caso de calificación culpable (así, STC 174/2003 en caso de pena de inhabilitación no solicitada por la acusación).

Segundo.- El sistema legal de la calificación concursal.

5. El Art. 164.1 dice que "El concurso se calificará como culpable cuando en la generación o agravación del estado de insolvencia hubiera mediado dolo o culpa grave del deudor o, si los tuviere, de sus representantes legales y, en caso de persona jurídica, de sus administradores o liquidadores, de derecho o de hecho"». 


\section{dad $^{28} \mathrm{o}$ hubiera cometido irregularidad «relevante $»^{29}$ para la comprensión de}

Son, pues, requisitos esenciales para la declaración del concurso culpable los siguientes: I) comportamiento activo o pasivo del deudor o de sus representantes legales, y, en caso de persona jurídica, de sus administradores o liquidadores, de derecho o de hecho; II) que ese comportamiento tenga una carga de antijuridicidad elevada, ya que ha de ser a título de dolo o culpa grave, no bastando ningún otro tipo de negligencia; III) un resultado: la generación o agravación del estado de insolvencia y IV) la relación de causalidad entre el comportamiento del sujeto afectado por la calificación y el resultado, es decir, que la generación o agravación del estado de insolvencia se deba a la actuación del declarado como culpable.

6. Junto a la cláusula general del Art. 164.1 LC, hay una serie de supuestos legales que aparecen en el artículo 164.2 y en el artículo 165 que tienen distinta naturaleza y alcance.

7. Los previstos en el artículo 164, son catalogados por algunos autores como presunciones iuris et iure, por lo que no admiten prueba en contrario y de la expresión empleada por la ley ("En todo caso, el concurso se calificará como culpable...") se infiere que abarca a todos los elementos exigidos para la declaración del concurso culpable. En palabras de la AP de Barcelona, Sección 15. a (Pte. Sancho Gargallo) "el Art. 164.2 tipifica una serie de conductas, cuya realización resulta suficiente para atribuir la calificación culpable al concurso, con independencia de si dichas conductas han generado o agravado la insolvencia, y que si en su realización el deudor ha incurrido en dolo o culpa grave" (sentencia de 19 de marzo del 2007) que en la sentencia de 27/4/2007 añade que “Esta expresión 'en todo caso' no admite margen de exención de responsabilidad basado en la ausencia de dolo o culpa grave, pues la culpa grave subyace a la mera realización de la conducta tipificada a continuación, ya que se estima que cuando menos constituye una negligencia grave del administrador".

8. En cambio, los supuesto del Art. 165 se califican como presunciones iuris tantum, y por tanto admiten prueba para desvirtuarlo, y solo se refieren al elemento subjetivo del comportamiento del sujeto pasivo, es decir, se presume la existencia de dolo o culpa grave en el sujeto pasivo, pero no se presumen el resto de los requisitos antes enumerados, que deberán ser acreditados por la parte que insta la declaración (la generación o agravamiento de insolvencia y la relación causal con el comportamiento del sujeto pasivo). Como dice la Audiencia Provincial de Córdoba de 28 de marzo 2008 aunque tienen la misma finalidad, sin embargo no tienen la misma amplitud aplicativa las presunciones iuris tantum del Art. 165 que las presunciones iuris et iure del Art. 164.2» indicando que "las presunciones de artículo 165 solo cubren el elemento subjetivo del dolo o culpa grave y no el resto de los requisitos que deberán ser cumplidamente acreditados", cosa que no ocurre con las del Art. 164.2.

Tercero.- El supuesto del Art. 164.2.1 LC.

9. Conforme al Art. 164.2.1. ${ }^{\circ}$ el concurso se califica como culpable cuando "el deudor legalmente obligado a la llevanza de contabilidad incumpliera sustancialmente esta obligación, llevara doble contabilidad o hubiera cometido irregularidad relevante para la comprensión de su situación patrimonial o financiera en la que llevara". Son, pues, tres las hipótesis legales equiparadas a efectos de declarar culpable en todo caso el concurso: a) no llevanza de contabilidad; b) llevanza de doble contabilidad y c) llevanza de contabilidad con irregularidades relevantes, que remarca la importancia que el legislador otorga a la contabilidad, que en el Art. 165.3 contempla como presunciones iuris tantum la del deudor que obligado legalmente a la llevanza de contabilidad "no hubiera formulado las cuentas anuales, no las hubiera sometido a auditoría, debiendo hacerlo, o, una vez aprobadas, no las hubiera depositado en el Registro Mercantil en alguno de los tres últimos ejercicios anteriores a la declaración de concurso", que vienen a catalogarse como conductas indebidas de menor intensidad. 


\section{su situación patrimonial o financiera de quien la llevara; II) cuando el deu-}

10. Conviene recordar que conforme a la regulación contenida en el CCo en la redacción anterior a 1/1/2008 (aplicable a los presentes autos) la mercantil concursada debe llevar una contabilidad ordenada, adecuada a la actividad de su empresa que permita un seguimiento cronológico de todas sus operaciones, así como la elaboración periódica de balances e inventarios. Por tanto, no basta solo el resumen anual sino que debe la contabilidad ofrecer la información cronológica de la vida económica de la sociedad y por eso dice el Art. 25 que se llevará necesariamente, sin perjuicio de lo establecido en las leyes o disposiciones especiales, un libro de Inventarios y Cuentas anuales y otro Diario. En tanto que el primero se abrirá con el balance inicial detallado de la empresa, transcribiéndose al menos trimestralmente con sumas y saldos los balances de comprobación y contendrá el inventario de cierre del ejercicio y las cuentas anuales, en el libro Diario se registrará día a día todas las operaciones relativas a la actividad de la empresa, admitiéndose la anotación conjunta de los totales de las operaciones por períodos no superiores al mes, a condición de que su detalle aparezca en otros libros o registros concordantes, de acuerdo con la naturaleza de la actividad de que se trate. Libros que deben presentarse al Registro Mercantil para su legalización, bien antes de su utilización (poniendo en el primer folio de cada uno diligencia de los que tuviere el libro y, en todas las hojas de cada libro, el sello del Registro), bien a posteriori (al ser válida la realización de asientos y anotaciones, por cualquier procedimiento idóneo sobre hojas que después se encuadernan correlativamente para formar los libros obligatorios) pero siempre antes de que transcurran los cuatro meses siguientes a la fecha de cierre del ejercicio, con la posibilidad de legalización a través de procedimientos telemáticos (Instrucción de la Dirección General de los Registros y del Notariado de 26 de mayo de 1999) y que deben ser llevados, cualquiera que sea el procedimiento utilizado, con claridad, por orden de fechas, sin espacios en blanco, interpolaciones, tachaduras ni raspaduras, salvándose a continuación, inmediatamente que se adviertan, los errores u omisiones padecidos en las anotaciones contables y sin que puedan utilizarse abreviaturas o símbolos cuyo significado no sea preciso con arreglo a la ley, el reglamento o la práctica mercantil de general aplicación y cuya conservación, durante seis años, a partir del último asiento realizado en los libros, le corresponde al empresario

11. En el caso presente son datos fácticos relevantes los siguientes:

I) el concurso de JOSIMASA SL se interesa el 18 de octubre de 2006 y tras trámite de subsanaciones en dos ocasiones por la deficitaria solicitud formulada, se declara por auto de 28 de noviembre de 2006 y en fecha 19 de noviembre de 2007 se apertura la fase de liquidación.

II) los Libros de contabilidad de Josimasa SL de los ejercicios 2004 y 2005 están legalizados el 1/6/2006 y 5/10/2006, respectivamente, por ende fuera de plazo del Art. 27.2 CCo vigente en el momento de los hechos, que prevé un plazo máximo de 4 meses siguientes a la fecha de cierre del ejercicio, que es a 31 de diciembre, según se aprecia de las cuentas anuales aportadas (hecho no controvertido y consta en el informe del Art. 75 LC), sin que consten legalizados los del ejercicio 2006.

III) constan depositadas las cuentas anuales de la concursada de los ejercicios 2003, 2004 y 2005 (hecho no controvertido y consta en el informe del Art. 75 LC).

IV) no consta que se facilitase a la admón. concursal los libros contables de la ejercicios 2004 y siguientes, ni consta la pérdida, sustracción o extravío.

V) interesada por la admón. concursal la contabilidad de los años 2004, 2005 y 2006 en soporte informático, se facilitó soporte informático por la concursada de la que manifiesta que obraba en su poder (según escrito de la misma y resoluciones obrantes en autos), sin que conste que reúnan las características técnicas impuestas para la legalización de libros en los 


\section{dor hubiera cometido «inexactitud grave» en cualquiera de los documentos}

Registros Mercantiles a través de procedimientos telemáticos ni que su contenido responda a las exigencias de integridad de los libros contables obligatorios.

12. Al margen de lo hechos no controvertidos, no aporta ningún dato ni prueba la concursada ni el administrador societario (Art. 217 LEC, principio de facilidad probatoria) acerca de que efectivamente los libros contables de preceptiva llevanza (Libros de Inventarios y Cuentas anuales y Libro Diario), fuesen facilitados a la admón. concursal, sin que haya razón alguna para dudar de la aseveración expuesta por este órgano independiente, de configuración legal plural y profesionalizado. No hay constancia ni documento alguno que advere que los libros de los ejercicios 2004 y 2005 legalizados en fechas inmediatamente anteriores a la solicitud de concurso (en un caso tres meses y medio y en otro escasos 13 días) hayan sido previamente entregados a la admón. concursal.

13. Libros que, conforme al Art. 30 CCo., su custodia le corresponde al empresario, e inclusive considerando (lo cual es ciertamente discutible) aplicable la prevención de los liquidadores a los administradores concursales, lo que no hay duda es que hasta la apertura de la fase de liquidación (aquí, en fecha 19/11/2007) tal custodia era carga del administrador societario, que desconoce todo lo relativo a su llevanza y control, y que aclara que no hay denuncia formulada por pérdida, sustracción o extravío.

14. En definitiva, se ignora qué contenían los libros legalizados de 2004 y 2005, en tanto que los del año 2006 ni siquiera se legalizan y se desconoce absolutamente su contenido, sin que los soportes informáticos facilitados permitan suplir su falta.

15. Ello es así por cuanto no son de aquellos que reúnen las notas y características técnicas que impone la Instrucción de la Dirección General de los Registros y del Notariado de 26 de mayo de 1999 para la legalización de libros en los Registros Mercantiles a través de procedimientos telemáticos, que en su Art. 5. 1 preceptúa que "La información presentada en soporte informático relativa a cada libro dispondrá de un sistema de protección con el objeto de garantizar la no manipulación desde la creación del soporte por la entidad o sujeto presentante y hasta que éste se incorpore al Libro-fichero de legalizaciones en el Registro Mercantil correspondiente. La protección se realizará mediante la utilización de claves de autenticación por medio del algoritmo estándar MD5", por lo que no reúnen los requisitos de fiabilidad, claridad y exactitud precisos, sin que conste que su contenido responda a las exigencias de integridad de los libros contables obligatorios (Diario e Inventario y Cuentas Anuales de 2004, 2005 y 2006), por lo que no aportan la información para poder discernir si existen irregularidades contables o doble contabilidad. Al no existir garantías de integridad no se puede determinar si ha habido ocultación de asientos o errónea contabilización de operaciones y su alcance.

16. Conviene traer a colación la reiterada la jurisprudencia del Tribunal Supremo recaída en el anterior derecho de quiebras (SSTS 27-3-87, 17- 4-90, 17-12-91, 22-11-1995, que cita otras más antiguas, como las de 24-4-1901, 17-6-1902, 5-11-1956, 7-2-1964, 6-12-1966 y 13-10-1969, seguidas además por nuestras Audiencias, como muestran las SSAP Valencia, sec. 8. a, de 1-3-2004, AP Palencia de 22-3-2002, AP Vizcaya, sec. 4. ${ }^{\text {a }}$, de 25-2-2002, o de esta misma Sala, AP Barcelona, sec. 15. a, de 14-3-2005 y 8-7-2004), que declaraba que es la falta de llevanza de libros de contabilidad oficiales la que determinaba que la conducta se calificase como presunción iuris et de iure de quiebra fraudulenta, indicando la SAP de Madrid de 19/10/2006 (Sección 28..$^{\circ}$ ) que a los efectos de interpretar el derogado Art. 890 del Código de Comercio de 1885: «Estos libros de comercio para que sean considerados como libros, a tales efectos, tienen que reunir los requisitos materiales (encuadernación, foliación y existencia de algún asiento) y formales (legalización en el Registro Mercantil, artículo 27 del Código de Comercio y artículos 296 a 298 del Reglamento del Registro Mercantil». De manera concreta, en un caso de aportación de soportes contables bajo la legislación derogada, que no impide la calificación de fraudulenta, la SAP de Madrid de 4 de julio de 2005. 


\section{acompañados a la solicitud de declaración de concurso o presentados duran-}

17. Por todo lo expuesto hay que concluir que los hechos descritos tienen su encaje en el Art. 164.1.2 LC (incumplimiento sustancial de la llevanza de la contabilidad), sin que el solo hecho de formular y depositar las cuentas de los años 2005 y anteriores y el facilitar un soporte informático en las condiciones descritas no lo excluye, como pretende la concursada y el administrador societario, ya que:

I) no hay constancia de contabilidad fehaciente correspondiente al ejercicio 2006 antes de la declaración de concurso ni después, recordando que cuando al concursado se le suspendieron sus facultades de admón. y disposición ello solo acaeció a partir del 19/11/2007, por lo que hasta ese momento no podía desligarse en ningún caso de sus obligaciones contables, aclarando el Art. 47.2 que durante la tramitación del concurso la formulación de las cuentas anuales corresponderá al deudor bajo la supervisión de los administradores concursales. Precisamente la contabilidad de ese año era esencial para averiguar la regularidad del comportamiento del deudor y determinar si se han producido pagos anticipados, extracciones sin justificar, traspasos indebidos o cualesquiera otras prácticas indebidas que no han podido ser objeto de análisis, como expone la admón. Concursal.

II) las cuentas anuales depositadas de los años 2005 y anteriores en todo caso no son bastantes, pues solo ofrecen un resumen anual de las magnitudes económicas globales de la empresa, pero la contabilidad debe además aportar la información diaria de la vida económica de la sociedad. Aquí se ignora ese movimiento diario (en los términos dichos) e individualizado, que es esencial, por otra parte, para conocer si la información global se ajusta o no a la realidad. La falta denunciada implica incumplimiento sustancial de la llevanza de la contabilidad, pues no se puede tildar su omisión como accesoria o auxiliar sino que es una pieza clave integrante de un solo todo o de un sistema de contabilidad preestablecido, de manera que su falta afecta a todo el sistema, que deja de ser lo que la Ley quiere, habiendo dicho la jurisprudencia (SAP de Madrid de 19/10/2006 bajo la legislación anterior, trasladable a la vigente) que "las cuentas anuales del ejercicio $\mathrm{X}$ hayan sido depositadas en el Registro Mercantil no suple la falta de los libros de comercio correspondientes a tal ejercicio"...

III) Se priva con ello de la información indispensable para conocer la situación patrimonial de la concursada y su evolución en los años inmediatamente anteriores a la declaración de concurso, de tanta trascendencia por ejemplo a efectos de declarar ineficaces actos perjudiciales (Art. 71 y ss).

18. El supuesto legal enjuiciado permite la declaración de culpable del concurso, bastante por sí para tal declaración, ya que este artículo 164.2 abarca a todos los elementos exigidos para la declaración del concurso culpable (SAP de Barcelona, Sección 15. ${ }^{a}$ de 19 de marzo del 2007) o como dice la SAP de Córdoba de 28 de marzo de 2008 "que en este supuestos de calificación del concurso, la tipificación de ilícitos civiles resuelve el problema de una relación de causalidad concreta, así como hace innecesaria la discusión de si la conducta es dolosa o la culpa es no grave" con apoyo en la doctrina jurisprudencial recaída sobre el Art. 890 CCo (STS 22/11/1985 según la cual "lo que alberga son normas de calificación de conducta y comportamiento, que al concurrir determinan necesariamente la calificación fraudulenta de la actuación del comerciante"), sin que sea preciso para su estimación perjuicio a los acreedores, pues no es exigencia legal (así, en la doctrina, entre otros, Machado).

Cuarto.- Las consecuencias de la calificación culpable.

19. Con arreglo al artículo 172, y dado que concurre el supuesto del Art. 164.2.1. ${ }^{\circ}$ LC (que hace innecesario el análisis del otro supuesto legal invocado) procede declarar el concurso como culpable, siendo D... de administrador de la persona jurídica deudora, sin que pueda servir de excusa el que carezca de conocimientos contables, pues es el administrador societario el responsable, sin que ello signifique que deba elaborar material o directamente 


\section{te la tramitación del procedimiento ${ }^{30}$, o hubiera acompañado o presentado}

el mismo. Si se encarga a tercero, responde en todo caso (Art. $25 \mathrm{CCo}$ ) al serle imputable la llevanza y custodia de los libros contables, sin que concurra causa eximente, que no puede ni el mero cese de actividad

20. Al citado D... se le impone la sanción de inhabilitación para administrar los bienes ajenos durante un período de cuatro años, así como para representar o administrar a cualquier persona durante el mismo período, que se considera ajustada a la entidad de los deberes contables incumplidos y su extensión temporal, pues esencial aparece en las sociedades capitalistas la contabilidad, dado que en un sistema de responsabilidad limitada son los únicos datos con los que cuentan los terceros a la hora de apreciar la solvencia de aquel con quien se relacionan o para comprobar que su actuación ha sido la correcta

21. En cuanto a los efectos patrimoniales, a la vista de que no han sido peticionados en los escritos de los legitimados activamente, no procede declaración alguna (Art. 218 LEC y $24 \mathrm{CE})$

Quinto.- La innecesidad de convocatoria social para cese.

22. Dado que el administrador de la persona jurídica concursada inhabilitado ya ha sido cesado en su cargo por imperativo del Art. 145.3 LC, deviene innecesario que la administración concursal convoque junta o asamblea de socios para el nombramiento de otro que haya de cubrir la vacante, prevista en el Art. 173.

Sexto.-Costas.

23. Al no existir una jurisprudencia consolidada por tratarse de una materia novedosa, no se efectúa imposición de costas (art. 394 de la L.E.C.).

Vistos los preceptos legales y demás de general aplicación al caso,

FALLO: Que estimado parcialmente las pretensiones formuladas por la Admón. concursal y el Ministerio Fiscal debo declarar y declaro:

que el concurso de JOSIMASA SL es culpable.

que el administrador de JOSIMASA SL, D... tiene la condición de persona afectada por la calificación.

${ }^{28}$ En cuanto al supuesto de llevanza de doble contabilidad, interesa la STS (Sala de lo Penal), de 30.01.1991: «Segundo. El juez civil calificó de fraudulenta por él declarada, por concurrir las circunstancias previstas en el artículo 891 del Código de Comercio... según los hechos declarados probados de la sentencia recurrida, en los que asienta la información cardinal de que la quebrada llevaba constantemente una doble contabilidad sistematizada que, por completo, afectaba a todo el montante comercial de la empresa, de manera que un gran número de operaciones comerciales quedaban solo reflejadas en la contabilidad oculta, llamada en la empresa Caja B, y detraídas al juego y resultado de la contabilidad transparente asentada en los libros oficiales que, por la razón dicha, no reflejaban la situación real de la empresa, y esa doble contabilidad que permitía al procesado ocultar en el balance cantidades en dinero, que procedía de las operaciones comerciales realizadas por la empresa, y del que en parte se lucraba, pone de manifiesto el ánimo de defraudar a los acreedores sociales, pues toda doble contabilidad tiene por finalidad ánimo defraudatorio, y el perjuicio real causado a estos al detraer del patrimonio alguna cantidad es causa, o al menos con causa determinante de la quiebra económica acaecida...».

${ }^{29}$ Juzgado de lo Mercantil n. ${ }^{\circ} 5$ de Madrid, de fecha 16 de febrero de 2006: «FUNDAMENTOS DE DERECHO. CUARTO.- La primera de las presunciones de concurso culpable invocadas es la contemplada en el tercer inciso del artículo 164.2.1. ${ }^{\circ}$ de la Ley Concursal, según el cual, el concurso se calificará como culpable, cuando el deudor legalmente obligado a la llevanza de la contabilidad, hubiere cometido, en la que llevare, irregularidad relevante para la comprensión de su situación patrimonial o financiera. 


\section{documentos falsos; III) cuando la apertura de la liquidación haya sido acor-}

Como se deduce del tenor literal del precepto, no basta la prueba de cualquier irregularidad en la llevanza de la contabilidad para tener amparo en la presunción sino que tiene que ser relevante para la comprensión de la situación patrimonial o financiera del deudor, esto es, tendrá que ser de la suficiente entidad como para incidir en la comprensión de su real situación patrimonial o financiera, precisamente porque esa irregularidad contable la desvirtúe.

En el informe de la administración concursal, y tampoco en el dictamen del Ministerio Fiscal, se concretan cuáles de los hechos invocados como relevantes para la calificación podrían integrar, a su juicio, la presunción ahora analizada, pero solo pueden tener encaje los señalados en los números 1, 2, 3, 4, 6 y 9 del fundamento anterior, al ser ajenos a la contabilidad el resto de los hechos reseñados.

1) Pago de cheques innominados y anticipos de remuneraciones.

Desde luego, no parece que puedan calificarse como irregularidad relevante que incida en la comprensión de la situación patrimonial o financiera de la sociedad deudora, los hechos descritos bajo esta rúbrica.

En la contabilidad figura un saldo acreedor por importe de 15.506,12 euros en la "cuenta corriente con administradores". Dicho saldo tiene origen en el pago de dos cheques por importe de 7.753,06 euros, sin que exista documento que justifique o soporte su pago, lo que constituye una irregularidad contable hasta el punto de que se discute, porque no resulta de la contabilidad, el concepto y la causa del pago, afirmando los propios administradores, don Miguel y don José, que están mal contabilizados en la cuenta corriente con administradores porque se trata de cantidades destinadas al pago de nóminas atrasadas, anticipos u otros gastos corrientes. Sin embargo, de las copias de los referidos cheques remitidas por las entidades bancarias, resulta que el cheque n..$^{\circ}$ 9.206.583 de la entidad Santander Central Hispano por importe de 7.753,06 euros, de fecha 1 de diciembre de 2003, fue cobrado por don Miguel (folio 1.315), y el cheque n..$^{\circ} 6.827 .856$ de la entidad BBVA, por idéntico importe, de fecha 29 de marzo de 2004, fue cobrado, cuando ya no era administrador, por don José (folios 1.291 y 1.292), estando estampada su firma en el reverso de los respectivos cheques bajo la expresiva rúbrica de "recibí".

Ahora bien, que dos de los administradores, de los cuales uno ya no lo era al emitirse el cheque, hayan percibido una cantidad sin estar justificado el pago y sin que estos hayan probado que materialmente los cheques fueran cobrados por empleados para su ingreso en caja con el objeto de atender necesidades de la empresa, lo único que determina es una deuda de los administradores con la sociedad, que es lo que refleja la contabilidad, por lo que la irregularidad contable antes señalada (pago sin documento o soporte contable que lo justifique) no incide en la compresión de la situación patrimonial o financiera de la sociedad, sin perjuicio de las consecuencias del cobro de esas cantidades.

De igual forma la existencia sin saldar de la cuenta denominada anticipos de remuneraciones por importe de 3.540.000 ptas., como consecuencia de anticipos en los años 1994, 1995, 1996 y 1997, puede considerarse una irregularidad contable en la medida en que no existe soporte documental del gasto ni, en consecuencia, la persona beneficiaria de dichos anticipos, debiendo haberse cancelado en los ejercicios correspondientes, pero carece de relevancia para la comprensión de la situación patrimonial o financiera de la sociedad.

2) Cancelación de saldos de contabilidad

No se discute que con fecha 30 de octubre de 2002, se cancelaron, mediante un apunte contable denominado "asiento asesoría", los saldos de determinadas cuentas por un importe total de 426.678,93 euros, concretamente las cuentas denominadas Caja Torre, Caja Suchil, Caja Alcocer y Caja Nave, correspondientes a los distintos establecimientos de la deudora y la denominada cuenta Copy. 


\section{dada de oficio por incumplimiento del convenio debido a causa imputable al}

La cancelación de dichos saldos no implica irregularidad contable, sino la necesaria regularización de una situación que no refleja la imagen fiel del patrimonio de la sociedad que, además, es consecuencia del informe de auditoría del ejercicio 2001. En dicho informe (folios 1.017 y 1.018) ya se pone de manifiesto que en el saldo de caja se incluyen efectivo, pagarés y recibos pendientes de ingresar en bancos a la fecha de vencimiento o de descontar, por un importe de 19.506.712 pesetas y no consta que el desfase entre las cuentas contables de caja y la tesorería obedezca a circunstancia distinta de la manifestada por la administradores, esto es, la práctica errónea anterior de contabilizar en caja, tanto efectivo como pagarés, que luego eran descontados, sin que se reflejase el menor valor percibido como consecuencia de las operaciones de descuento, lo que arrastraba saldos ficticios acumulados de muchos años.

Por otra parte, en el informe de auditoría también se indica la salvedad derivada de no cancelar saldos de difícil realización derivados de ventas a clientes y prestaciones de servicio, precisamente por el importe que refleja la denominada cuenta Copy (54.155.742 pesetas equivalentes a $325.482,56$ euros).

En definitiva, podrá imputarse a los administradores la tardía eliminación de unos saldos inexistentes, lo que se analizará en otro apartado, pero no la regularización derivada de su cancelación.

3) Irregularidad contable.

En las cuentas del ejercicio 2002 se efectúa un ajuste de reservas contra ingresos extraordinarios en la cuantía de 272.080,83 euros, lo que determina que el resultado del ejercicio antes de impuestos, sea de $-249.696,22$ euros en lugar de $-521.777,05$ euros.

En la memoria del ejercicio 2002 (folio 222), se especifica que "Los gastos y pérdidas de ejercicios anteriores recogen una serie de regularizaciones de cuentas, fundamentalmente saldos deudores de difícil realización y otros ajustes, que han surgido en este año como consecuencia de una depuración de la contabilidad. Debido a que las pérdidas, puestas de manifiesto en este ejercicio, se generaron y provienen de ejercicios anteriores, se han registrado dentro de este epígrafe de 'gastos y pérdidas de ejercicios anteriores' ya que no tendría sentido considerarlas como resultados de la explotación del año 2002.

Como consecuencia de lo explicado en el párrafo anterior y debido precisamente a que las pérdidas ahora registradas provienen de ejercicios anteriores se ha decidido, y así se propondrá a la Junta General de Accionistas, disminuir las reservas disponibles hasta su cancelación, pues es claro que en ejercicios anteriores se registraron beneficios superiores a los que en realidad correspondían. Por tanto, se ha disminuido el saldo de las reservas mencionadas (ver Nota 9) abonándolas a ingresos y beneficios de otros ejercicios".

Con independencia de que la forma en que se afloran las pérdidas de ejercicios anteriores, no contabilizadas en los mismos, pueda ser una irregularidad contable, dicho proceder no afecta a los fondos propios de la sociedad, como reconoce la propia administración concursal, siendo idéntica su situación patrimonial aunque se imputasen todas las pérdidas al ejercicio 2002. Por ello, no cabe entender que la irregularidad contable afecte a la comprensión de la situación patrimonial o financiera de la sociedad, cuando, además, en la memoria, que forma parte de las cuentas anuales (artículo 172 del Texto Refundido de la Ley de Sociedades Anónimas), se informa y comenta el motivo y la forma en que se van a contabilizar esos menores beneficios de otros ejercicios. Por lo demás, el propio auditor de la cuentas, en la prueba testifical, reconoce que el criterio seguido para contabilizar esas pérdidas no afecta a la imagen fiel de la situación patrimonial de la sociedad.

4) Actos encaminados a simular una apariencia de solvencia.

La administración concursal ha acreditado que la concursada ya se encontraba, al menos, en causa de disolución a 31 de diciembre de 2001, sin que las cuentas de ese ejercicio reflejasen 


\section{concursado; IV) cuando el deudor se hubiera alzado con la totalidad o parte}

tal situación, al incluir en el activo, de forma incorrecta desde el punto de vista contable, un crédito fiscal por importe de $91.462,23$ euros y los saldos de las cuentas de caja y copy a los que antes se ha hecho referencia por importe de 426.678,93 euros.

El propio informe de auditoría de las cuentas del ejercicio 2001 pone de manifiesto estas irregularidades (folios 1.017 y 1.018). Así, respecto de las cuentas de caja el párrafo tercero del informe de auditoría indica que "De igual modo no opinamos sobre el saldo de caja que incluye efectivo, pagarés y recibos pendientes de ingresar en bancos a la fecha de vencimiento o de descontar, el cual aparece incluido en el epígrafe tesorería del Activo del Balance de Situación por un importe de 19.506 .712 pesetas".

Por lo que se refiere a la denominada cuenta copy, el párrafo quinto del informe de auditoría señala que "El epígrafe de clientes por ventas y prestaciones de servicios, incluidos en el activo del balance de situación recoge saldos por un total aproximado de 54.155.742 pesetas que consideramos de difícil realización. Por tanto, los saldos del epígrafe de clientes por ventas y prestaciones de servicios y los del epígrafe de fondos propios deberían disminuirse en el importe mencionado".

Como ya quedó expuesto con anterioridad, la sociedad mediante un apunte contable denominado "asiento asesoría" realizado el 30 de octubre de 2002, suprimió parcialmente los saldos de caja (16.837.659 ptas.) y en su totalidad el de la cuenta copy (54.155.742 pesetas), por un importe total de 426.678,93 euros, reflejándose en la cuentas del 2002 como gastos de otros ejercicios.

Es evidente, que si la tesorería de la empresa al 31 de diciembre de 2001, no mantenía los saldos que reflejan las citadas cuentas (al margen de incluir como tesorería lo que no lo era) y si existían saldos por ventas y prestaciones de servicios de dudosa realización, los resultados del ejercicio 2001 debían haberse minorado en el importe de 426.678,93 euros, como reconoce la propia concursada en sus cuentas del 2002, que incluye como gastos de otros ejercicios la citada cuantía. Esto es, la pérdida ya existía a 31 de diciembre de 2001 y lo conocían o debían conocerlo los administradores al formular las cuentas y, en todo caso, al ponerlo de manifiesto el informe de auditoría, sin necesidad de esperar a contabilizarlo en el siguiente ejercicio, porque altera las cuentas del ejercicio $2001 \mathrm{y}$, en consecuencia, estas no reflejan la imagen fiel del patrimonio y situación financiera de la sociedad.

Por último, en cuanto al crédito fiscal, la auditoría pone de manifiesto que "La sociedad ha registrado un crédito fiscal en concepto del menor impuesto sobre sociedades que se devengará en ejercicios futuros, cuando consiga beneficios suficientes que compensen la base imponible negativa obtenida en el presente ejercicio. Las normas de contabilidad generalmente aceptadas exigen que el crédito fiscal únicamente se reconozca en el caso de que se cumplan determinadas circunstancias, entre otras, que la pérdida se haya producido como consecuencia de un hecho no habitual en la empresa y que las causas que la originaron hayan desaparecido en la actualidad. Al no cumplirse estos requisitos, pues la pérdida no se ha producido como consecuencia de circunstancias excepcionales, estimamos que las pérdidas del ejercicio deberían aumentarse en 15.866 .544 pesetas y el crédito frente a la Hacienda Pública disminuirse en el citado importe. Este menor impuesto sobre sociedades a pagar se debería recoger en el ejercicio en que efectivamente se obtengan bases imponibles positivas suficientes para su compensación".

La salvedad del auditor tiene apoyo en la resolución del Instituto de Contabilidad y Auditoría de Cuentas (ICAC) de 9 de octubre de 1997 (BOE de 6 de noviembre de 1997), la cual establece que "Los créditos derivados de la compensación de bases imponibles negativas sólo serán objeto de registro contable cuando la base imponible negativa se haya producido como consecuencia de un hecho no habitual en la gestión de la empresa, siempre que 


\section{de sus bienes en perjuicio de sus acreedores ${ }^{31}$ o hubiera realizado cualquier}

razonablemente se considere que las causas que la originaron han desaparecido en la actualidad y que se van a obtener beneficios fiscales que permitan su compensación en un plazo no superior al previsto en la legislación fiscal para la compensación de bases imponibles negativas, es decir, siete años con carácter general, y con el límite máximo de diez años contados desde la fecha de cierre del ejercicio en aquellos casos en los que la legislación tributaria permita compensar en plazos superiores".

En el ejercicio 2001, la sociedad sufrió pérdidas de 177.096, 86 euros (folio 201), que en realidad eran de 603.775,79 euros (177.096,86 euros más 426.678,93 euros), derivados de su actividad ordinaria, pues en las cuentas solo se reflejan unos gastos extraordinarios de 943,59 euros.

Por otra parte, frente a la opinión del auditor, refrendada por irrefutable realidad de lo acaecido con posterioridad, no cabe oponer el informe pericial aportado por la representación de don Miguel (folios 1019 a 1025), que se asienta sobre las propias manifestaciones de los administradores en el informe de gestión y, en todo caso, si existían dudas, el principio de prudencia contable imponía la no activación del crédito fiscal, sin que se haya acreditado en esta sección que las pérdidas obedecieran a hechos no habituales en la gestión de la empresa y menos aún cabe pretender activar el crédito alegando su futura compensación con las plusvalías derivadas de la realización de los inmuebles de la sociedad, pues ello implica su liquidación y la contabilidad responde al principio de empresa en funcionamiento.

De no haberse computado, como se hizo indebidamente, los saldos antes reseñados y el crédito fiscal, los fondos propios de la sociedad estarían minorados en 518.141,16 euros, de modo que las cuentas del ejercicio 2001 en lugar de fijar unos fondos propios de 489.997,63 euros, debían reflejar unos fondos propios negativos de $-28.143,53$ euros, todo ello con un capital social de 181.505,66 euros.

Las irregularidades contables reseñadas, son relevantes para la compresión patrimonial y financiera de la sociedad, hasta el punto de que enmascaran la causa de disolución prevista en el artículo 260.1.4. ${ }^{\circ}$ de la Ley de Sociedades Anónimas, cuando no la misma quiebra de sociedad en dicha fecha e integran la presunción de concurso culpable del artículo 164.2.1. ${ }^{\circ}$ de la Ley Concursal, cuya declaración debe efectuarse en esta resolución.

A mayor abundamiento, se comete la misma irregularidad, respecto a la activación del crédito fiscal, en las cuentas del ejercicio 2002 (folio 229), de las que resultan unos fondos propios de 1.394 euros y en el balance cerrado a 30 de junio de 2003 (folio 296). Este balance se formuló con el objeto de proceder a la reducción del capital y simultánea ampliación mediante compensación de préstamos, resultando a esa fecha unos fondos propios negativos de $-34.554,95$ euros (folio 745), y tras la adopción de las medidas de reducción y ampliación de capital en la Junta General, éste quedó fijado en 78.088 euros con unos fondos propios de 43.533,05 (según resulta del mismo informe de la administración concursal y, concretamente del folio 745 de esta pieza), por lo que si consideramos que en dicho balance se contabilizó indebidamente en el activo, como crédito fiscal, la cantidad de 19.357,61 euros, cuando debía contabilizarse como perdida con disminución de los fondos propios, las medidas de reestructuración del capital eran insuficientes al continuar el patrimonio contable $(43.533,05-19.357,61)$ por debajo de la mitad de la cifra de capital social $(78.088,2)$, por lo que, de nuevo, el balance formulado por los administradores cerrado a 30 de junio de 2003 , contenía una irregularidad relevante para la comprensión de la situación patrimonial o financiera de la sociedad. 


\section{acto que retrase, dificulte o impida la eficacia de un embargo en cualquier}

QUINTO.- No habiéndose precisado los hechos que podrían constituir actos jurídicos tendentes a simular una situación patrimonial ficticia y no apreciando que ninguno de los alegados pueda integrar la presunción legal prevista en el artículo 164.1.4 de la Ley Concursal, la misma no es de aplicación al supuesto enjuiciado, lo que es irrelevante a los efectos de la calificación, a la vista del fundamento anterior». D. Alberto Arribas Hernández.

Juzgado de lo Mercantil n. ${ }^{\circ} 1$ Donostia - San Sebastián, de fecha 28 de julio de 2006: «FUNDAMENTOS DE DERECHO. TERCERO.- Por ultimo... queda por determinar si ha habido irregularidad relevante en sus obligaciones contables que REPSOL centra en que, a pesar de haberse hecho una provisión contable de 458.992,78 euros para cubrir la posible indemnización de daños y perjuicios, no consta, atendiendo la masa activa fijada en el informe definitivo de la Administración Concursal que se hubiese dotado por el liquidador dicha provisión con la cuenta de resultados de la sociedad, lo que lleva a REPSOL a suponer que se habrían destinado activos de la sociedad a un fin distinto del establecido en su contabilidad.

Por su parte, el Ministerio Fiscal también incide en que los perjuicios han ido aumentando con el paso del tiempo y con la continuidad de la actividad, no produciéndose un aumento de la provisión por parte del liquidador de la sociedad.

Respecto a lo anterior, el Administrador Concursal considera que la concursada llevaba correctamente su contabilidad, sin que aprecie en ella defecto importante alguno, habiendo formulado las cuentas anuales y realizado su depósito en el Registro Mercantil.

De lo anterior se deduce que el liquidador de la sociedad, Sr. Lecuona provisionó contablemente la deuda líquida generada por la sentencia en primera instancia, con lo que el deber contable quedó cumplido, sin perjuicio de que la provisión era insuficiente, pues no cubría la deuda pendiente de liquidación; posteriormente, la revocación parcial de la sentencia dictada en primera instancia hace que toda la deuda deba de liquidarse, por lo que no podemos tener constancia cierta de que la provisión contable sea o no capaz de cubrir la deuda.

Cuestión diferente es que tal provisión contable no haya sido objeto de ninguna dotación económica por parte de liquidador de la sociedad, el cual procedió a la disolución y liquidación de la sociedad como consecuencia de la sentencia dictada en primera instancia, pero, sin embargo, no consta que haya realizado actuación alguna para proceder a tal liquidación sino que ha seguido explotando de forma normal la estación de servicio, sin atender a las funciones propias de los liquidadores establecidas en el art. 272 de la L.S.A., entre las que están, como mas principales, las de realizar las operaciones necesarias para proceder a la liquidación de la sociedad, enajenar sus bienes y pagar a los acreedores.

Sin embargo, lo anterior no se puede considerar como una irregularidad contable, causa que ha alegado REPSOL y que nos vincula a la hora de resolver, pues las obligaciones contables fueron correctamente atendidas por el Sr. Lecuona, como indicó la Administración Concursal, sino que, en su caso, tal conducta podría ser encuadrable en otras causas de culpabilidad (por ej. las de los puntos $4 .^{\circ}$ y $5 .^{\circ}$ del art. 164.2 de la L.C. por no haberse aplicado los presumibles beneficios derivados de la explotación a cubrir la provisión para atender la indemnización que habría que abonarse a REPSOL).

Sin embargo, tal causa de culpabilidad no ha sido alegada en esta pieza, por lo que no se puede resolver sobre la misma al impedirlo el principio dispositivo.

En consecuencia, solo procede declarar el concurso culpable por las causas contenidas en los arts. 164.1 y $165.1 .^{\circ} \gg$. D. Pedro José Malagón Ruiz.

${ }^{30}$ Sentencia del Juzgado de lo Mercantil N. ${ }^{\circ} 2$ de Bilbao, de fecha 3 de octubre de 2007, afirma: «Además de la recogida en el art. 164.2.5.. ${ }^{\circ}$ L 22/2003 de 9 Jul. (concursal) -que resulta claramente acreditada, al haber dispuesto injustificadamente el administrador único de importantes cantidades de dinero en favor de sus cuentas personales desde las de la 


\section{clase de ejecución iniciada o de previsible iniciación; V) cuando durante los}

concursadas-, se invocan como causas de culpabilidad del concurso las prevenidas en los ordinales $1 .^{\circ}$ y $2 .^{\circ}$ del mismo precepto -irregularidad contable relevante para la comprensión de la situación patrimonial o financiera de la concursada, e inexactitud grave en documento contable acompañado al procedimiento-. Siendo ello así, es de señalar que consta como probado que los depósitos registrales de cuentas y sus documentos contables mismos se encontraban deficientemente formulados, arrastrándose y acumulándose desde 2002 en los sucesivos ejercicios, de forma que en tales existía un importante monto de fondos propios irreal, y una manifestación de resultados positivos «hinchada» o de los negativos del ejercicio 2004 «desinflada», y que ha sido muy difícil así presentar un resumen de la evolución patrimonial y financiera de la concursada al primer orden de control o aviso de insolvencia de cara al mercado.

De esta manera la verdadera situación de la empresa no podía deducirse de los libros que llevaba y publicaba, cuando se hayan tenido en cuenta, como ciertos y veraces en una regular contabilidad, determinados datos, por lo que ello, que está detrás de la presunción de concurso culpable, opera plenamente. Frente a la calificación del concurso como culpable conforme al art. 164.2.1. ${ }^{\circ}$ y $2 .^{\circ} \mathrm{L} 22 / 2003$ de 9 Jul. (concursal), no son asumibles los argumentos que aducen los afectados en tanto en cuanto la contabilidad no es una abstracción que todo lo permite sino un método para hacer constar de forma real y transparente el estado económico de un comerciante. Se ha alegado que, salvo la revaloración de inmovilizado, el resto son divergencias de criterios contables, las cuales se contemplan desde la perspectiva de la insolvencia, en lugar de hacerlo desde el punto de vista contemporáneo a la aprobación y depósito de cuentas. Ante ello debe aseverarse: a) el prisma de valoración es cabalmente el coherente con la producción del daño y desde que éste se produce -daño que supone la insolvencia como impotencia de satisfacer regularmente a los acreedores-, valorando lo "relevante" en la probabilidad teórica de que se hubiera evitado o mitigado, no en la prueba de una real relevancia para determinadas decisiones comerciales. Si se tratara de situarse en el momento histórico de aparecer la irregularidad, y de causalizarla en concreto, no se estaría ante una presunción iuris et de iure que traslada un juicio de prudencia a la conducta, como válvula de escape, sino en el supuesto general del art. 164.1 L 22/2003, y b) siempre es relevante lo que supone conculcar en las cuentas los principios de contabilidad generalmente aceptados, a saber, prudencia, registro, precio de adquisición, devengo, correlación de ingresos y gastos, etc.». D. Edorta Josu Etxarandio Herrera.

${ }^{31}$ Puede servir de referencia en este supuesto la jurisprudencia dedicada al mismo hecho, en el procedimiento de quiebra (art. 890.1 del C. de C.), la Sentencia del TS de 10.12.1985, recogida por Baró Casals: «... ha quedado probado mediante recibos el pago de escrituras de compra de un chalet a nombre de la esposa del administrador de la indicada sociedad quebrada, generando en consecuencia, con independencia del resultado que deparase el examen que pudiera llevarse a cabo de la expresada contabilidad que se dice sustraída, supuestos de fraudulencia comprensibles..., dado que... no puede negarse que de tener un normal destino perceptor contable aquella suma superadora de los veinte millones de pesetas y los seis millones obtenidos, por préstamo personal, del Banco..., fácil sería a la entidad quebrada, de no existir anormalidad alguna que enmarque en la circunstancia quinta de dicho artículo ochocientos noventa, acreditarlo mediante medios probatorios independientes de la contabilidad reflejada en los relacionados libros que se dicen sustraídos, y no lo ha efectuado en tiempo adecuado y oportuno, y de tener una causa normal la relacionada adquisición del expresado chalet, no encajable en consecuencia dentro del ámbito de la precitada circunstancia doce del repetido artículo ochocientos noventa, también fácil hubiera sido destruir la lógica presunción de estarse en presencia de compra puesta a nombre de tercera persona en 
dos años anteriores a la fecha de la declaración de concurso hubieran salido fraudulentamente del patrimonio del deudor bienes o derechos; y VI) cuando antes de la fecha de la declaración de concurso el deudor hubiese realizado cualquier acto jurídico dirigido a simular una «situación patrimonial ficticia» ${ }^{32}$.

perjuicio de acreedores, toda vez que no resulta comprensible en el normal actuar humano el que, sin acreditación de causa justificante alguna y estando abocado a un desfase económico perjudicial, que incluso llevó a la solicitud de declaración de quiebra, satisfaga el importe de adquisición que se pretende efectúa con desvinculación patrimonial del quebrado que atiende a abonos a cargo de la adquisición llevada a cabo».

32 Juzgado de lo Mercantil N. ${ }^{\circ} 1$ de Madrid, de fecha 16 de enero de 2007: «FUNDAMENTOS DE DERECHO. TERCERO.- 1. Depurada en el modo como lo ha sido la controversia, procede ahora abordar cuáles son los hechos que, a juicio de la Administración concursal, pueden conducir a que el concurso de la entidad Núcleos de Organización y Administración, S.A. sea calificado como culpable, y a quienes son imputables tales actos en la hipótesis que procediera tal calificación.

2. El primero de los hechos en virtud de los que la Administración concursal pretende la calificación del concurso como culpable consiste en lo que se ha calificado como "simulación de una situación patrimonial ficticia" (artículo 164.2.6. ${ }^{\circ}$ LC). La Administración concursal sustenta que concurre tal causa de calificación del concurso como culpable porque la entidad concursada aportó con la solicitud de declaración de concurso un "Plan de Liquidación" del que se desprendía la posibilidad de satisfacer la masa pasiva hasta un $60 \%$ de sus respectivos créditos cuando en realidad el pago que podrá hacerse a los acreedores concursales será muy inferior. La acusación que formula la Administración concursal no es, en este caso, genérica puesto que en el párrafo segundo del hecho primero del informe de calificación se dice que "del informe de la administración concursal y del escrito proponiendo un plan de realización de los bienes y derechos de la sociedad se deduce que, de no cobrarse el saldo deudor de la sociedad AFA PRESS U.K. el importe a cobrar por los acreedores será meramente simbólico". Y no le falta razón a la Administración concursal cuando realiza esta afirmación toda vez que del Informe aportado según lo previsto en el artículo 74 LC, en fecha 9 de marzo de 2006, se desprende que el saldo deudor de la entidad AFA PRESS UK Ltd. a favor de la entidad concursada era de 2.714 .648 euros (pág. 12 primer párrafo del Inventario) de un total de 4.682.389,28 euros (pág. 1 del Inventario). Esto supone el 57,97\% del valor total del activo. Sin embargo, el artículo 164.2 LC recoge la conducta del deudor consistente en cometer «inexactitud grave en cualquiera de los documentos acompañados a la solicitud de declaración de concurso o presentados durante la tramitación del procedimiento». No parece que el hecho de que la entidad Núcleos de Organización y Administración, S.A. incluyese en el Plan de Liquidación y en el Inventario presentados con la solicitud de declaración de concurso la aludida partida pueda considerarse "inexactitud grave", puesto que en el informe de calificación presentado por la Administración concursal ésta denota sólo cierta inseguridad en las posibilidades de obtener el pago de dicha cantidad pero no la inexistencia del derecho a percibir dicha partida. Nótese que la Administración concursal dice que "de no cobrarse el saldo deudor de la sociedad AFA PRESS U.K. el importe a cobrar por los acreedores será meramente simbólico". De lo trascrito se desprende que lo que se denuncia no es inexactitud en el "Plan de Liquidación" presentado por la entidad concursada sino solo que si finalmente no se logra percibir la cantidad adeudada por la entidad AFA PRESS UK Lda. -lo cual en estos manetos se encuentra en manos de la Administración concursal ex artículo 54.1 LC- quedarán frustradas las expectativas de los acreedores. Y dicha circunstancia no derivará de que en el referido Plan de Liquidación se consignaran datos 


\section{Análisis de la jurisprudencia reciente relativa a la responsabilidad de los administradores sociales ${ }^{33}$}

El caudal de jurisprudencia sobre la responsabilidad de los administradores societarios es muy abundante, pero se centra en aspectos que no constituyen la médula de nuestro interés. Podríamos decir que se trata de cuestiones más bien formales las que son objeto de consideración por el Alto Tribunal (carácter casi objetivo de la responsabilidad de instar la disolución en caso de causa legal de disolución, ex art. 262.5 L.S.A.; plazo de prescripción; determinación del término inicial de su cómputo...), pero en lo relativo al contenido material de la función administradora, al nivel de exigencia en su desarrollo y a la existencia de causas que exoneran de responsabilidad, la orfandad jurisprudencial es manifiesta. O, al menos, falta la construcción de una «doctrina general» sobre todo ello, pues las declaraciones judiciales atienden a las características del caso particular y a su concreta resolución, advirtiéndose en el proceso de la decisión judicial una especie de «salto»: desde la ley general (construida con conceptos vagos o con patrones estándares de conducta) se pasa a los hechos del caso concreto y, mágicamente (según una «impresión» judicial, posiblemente certera pero no explicitada en un discurso intelectual) se produce la subsunción y se precipita la resolución. Falta, para que todo el «discurso» quede bien trabado o eslabonado, aproxi-

falsos tendentes a simular una situación patrimonial ficticia, sino de que uno de los mayores activos no podrá finalmente ser hecho efectivo. Además, téngase en cuenta que la Administración concursal incluyó en el epígrafe II.5 "Deudores" del Inventario de la entidad concursada que el saldo a favor de esta según el Balance aportado al Juzgado era de 4.221.263,90 euros, que según el "Plan de Liquidación»" presentado por el deudor al Juzgado de lo Mercantil era de 4.221.263 euros, y que según la Administración concursal era de 4.221.264 euros. Se consigna, además, a propósito de dicho epígrafe que "este saldo de 2.714.648,00 corresponde al cliente AFA PRESS UK Ltd. y figura pues en las tres fuentes que estamos utilizando(...) en nuestra opinión, con los datos e información de que disponemos en la actualidad y condicionando nuestro criterio a que en su momento pueda acreditarse documentalmente lo contrario, hemos de considerar aplicable el art. ${ }^{\circ} 58$ de la LC: no existían requisitos necesarios para que por la sociedad se llevara a cabo la compensación de ambos saldos, estimando esta operación improcedente de conformidad con el citado art. ${ }^{\circ} 58$ de la LC y por lo tanto, hemos de mantener el derecho de NOA - de sus acreedores- a recuperar el saldo deudor". Estas manifestaciones impiden que se pueda considerar que la inclusión de dicha partida tanto en el inventario aportado por la deudora junto con la solicitud como su consignación en el plan de liquidación suponga la simulación de una situación patrimonial ficticia. La condicionalidad con la que se expresa la Administración concursal sobre este extremo es del todo punto incompatible con la inexactitud grave a la que se refiere el precepto más arriba trascrito». D. Antoni Frigola i Riera.

${ }^{33}$ Las sentencias que citaremos a continuación obedecen a una selección propia. Para una reseña jurisprudencial más amplia desde el punto de vista temático, puyes alcanza a todo el ámbito de las sociedades anónimas y limitadas, y no exclusivamente a la responsabilidad de los administradores, ver F. MARín CASTÁn, Sociedades Anónimas y de Responsabilidad Limitadaed, La Ley, Madrid, 2007. pp. 81-319 y 576-597. 
mando más los dos hitos de los hechos particulares a los principios legales abstractos o los conceptos vagos que esta emplea para caracterizar los deberes del administrador, un «desarrollo» o explicitación del significado de esos principios o normas principiales ${ }^{34}$.

A continuación presentamos una muestra que nos parece significativa de las sentencias recientes del Tribunal Supremo recaídas en materia de deberes y responsabilidad de los administradores. La sistematización se ha realizado del siguiente modo: primero se han recogido las sentencias sobre los deberes fiduciarios, donde figuran sucesivamente las que se refieren a la diligencia, a la fidelidad (o buena fe) y a la lealtad de los administradores; y a ellas siguen las sentencias sobre responsabilidad de los administradores, entre las que destacan por su frecuencia las que se refieren a la responsabilidad (casi) objetiva ex art. 262.5 L.S.A. por no promover los administradores la disolución de la compañía cuando concurre causa legal para ello, y después se continúa con las que analizan la prescripción de la acción de responsabilidad contra los administradores (también muy frecuentes); por fin, se incorporan unas sentencias sobre aspectos heterogéneos, pero que todos ellos tienen que ver con elementos nucleares de la responsabilidad de los administradores.

${ }^{34}$ El empeño, en cualquier caso, no es fácil. En los países de Common Law la orfandad legislativa de origen propiciaba y propició una mayor activismo judicial. Hoy en día el grado de normativización del Derecho de Sociedades es ya bastante intenso tanto en los Estados Unidos como en el Reino Unido. No obstante, la tradición de la mayor «densidad jurisprudencial» ha ayudado a abordar las cuestiones que caen bajo nuestro análisis (deberes y responsabilidad de los administradores) con un discurso más consistente. Allí, los tribunales han ido elaborando un cuerpo de doctrina que se vertebra sobre la base de unos principios deducidos de categorías más generales pero que, al menos atendiendo a la frecuencia y reiteración con que se aplican por los juzgadores, permiten hablar de un proceso en la aplicación del Derecho que no presenta las soluciones de continuidad o el «salto de página» que encontramos en otros países. Dicho lo cual, sin embargo debe llamarse inmediatamente la atención sobre dos extremos: a) que esos hitos o conceptos que sirven para la argumentación en que se resuelve la aplicación del Derecho por los jueces no son dogmáticos, sino abiertos a mutaciones o adaptaciones; y b) que la panacea no es absoluta. «No es oro todo lo que reluce», o el brillo que parece desde la distancia desprenderse de la realidad judicial anglosajona, a medida que nos acercamos a ella comienza a apagarse. Pues esas categorías, conceptos o hitos que, desprendidos de ideas más abstractas, nos permiten «acercarnos» a la solución del caso, a la comprensión jurídica de los suceso vitales sometidos a enjuiciamiento, no tienen siempre la consistencia que sería de desear. Estos pilares sobre los que construye el juez su respuesta son, con más frecuencia de la deseable, «pilares de goma», con lo que quiere expresarse que ofrecen la ductilidad suficiente como para que, en función del temperamento del juzgador, depare la aplicación de un mismo hito a dos sucesos similares soluciones judiciales contradictorias. Y de esto es de lo que se trata aquí: de asegurar la previsibilidad de la respuesta judicial, la seguridad jurídica, la que se ve que no queda garantizada en ningún sistema. Pero todo lo expuesto nos retrotrae al inagotable debate del rol que corresponde a legislador y al juez en la construcción del Derecho, y esto es algo que nos sobrepasa en este momento. 
Se han reflejado los antecedentes de hecho, tomándolos de la propia sentencia, en los casos en que se ha considerado completamente necesario para la mejor comprensión de su fundamentación jurídica.

La sistematización se ha hecho en función de la cuestión que aparecía como más relevante en la argumentación de cada sentencia, pues se daba con frecuencia el caso de que en una misma sentencia aparecían implicadas diversas cuestiones de las que nos han servido como epígrafes o criterios de ordenación.

\section{A) SOBRE LOS DEBERES FIDUCIARIOS DEL ADMINISTRADOR}

\section{Falta de diligencia del administrador}

I ${ }^{35}$ «... sobre la base de que en el momento en el que sucedió el accidente en el que resultó lesionado el trabajador de "ABRILLANTADOS, LIMPIEZAS Y SERVICIOS, S.L.", el administrador único de esta era el demandado Sr. Germán, quien era dueño de 545 de las 550 participaciones de la empresa y fue ratificado en su cargo después del accidente del Sr. José Ignacio, señalando que, obviamente, al tratarse de una pequeña empresa era el Sr. Germán quien daba las pertinentes instrucciones a sus empleados y quien debía dotarles de las medidas de seguridad que resultaran precisas, y que de la prueba practicada resulta que el administrador demandado envió al Sr. José Ignacio, y a otros dos operarios, a efectuar labores de limpieza a una Guardería Infantil, para lo que debían salir al alféizar de la ventana y limpiarla desde el interior, como se indica en la Sentencia del Tribunal Supremo de 21 de diciembre de 1999, en la que se relata que el operario realizaba esta labor sujetándose con una mano al techo del inmueble mientras con otra limpiaba los cristales, no habiendo facilitado la Empresa cinturón de seguridad, pues solo disponía de uno en mal estado de funcionamiento, debiendo destacarse que esas labores se llevaban a cabo a más de cuatro metros de altura, por lo que entrañaban notable riesgo. Añade la Audiencia que esa falta de medidas de seguridad se recoge, asimismo, en la Resolución de la Dirección Provincial de Trabajo y Seguridad Social de 30 de octubre de 1991, que impuso a la empresa una sanción de 500.000 pesetas, confirmada por la Dirección General de Trabajo. La conducta del Administrador en el cometido propio de su función se considera por el Tribunal de apelación como un incumplimiento grave de sus obligaciones, por lo que de conformidad con lo establecido en los arts. 69 de la LSRL y 133 y 135 del TRLSA, debe responder del daño causado por la falta de diligencia».

${ }^{35}$ STS de 23 de octubre de 2008, Recurso 286/2004 (ponente AlmaGRo NOSETE). 
II) ${ }^{36}$ En esta sentencia se hace una breve referencia al deber de diligencia de los administradores en relación con la aplicación del art. 262.5 y los 127, 133 y 135 L.S.A.

\section{«FUNDAMENTOS DE DERECHO}

PRIMERO.- El objeto del proceso versa sobre responsabilidad de administradores de una sociedad anónima respecto de los que se ejercita por una entidad acreedora de la entidad las acciones individual de responsabilidad por daño y la de responsabilidad por deuda social.

Por la entidad BANCO BILBAO VIZCAYA, S.A. (BBV) se dedujo demanda contra Dn. Carlos Alberto, Dn. Gregorio y Dn. Pablo, en concepto de administradores en su día de la sociedad Fricuenca S.A. en reclamación de la cantidad de cuarenta y siete millones seiscientas sesenta mil ochocientas cuarenta pesetas -47.660 .840 pts.-, que es la deuda que Fricuenca S.A. tiene con la actora. Se ejercita con carácter principal la acción individual de los arts. 127, 133 y 135 de la Ley de Sociedades Anónimas TR de 22 de diciembre de 1989, con base en el grave y negligente incumplimiento de las obligaciones legales inherentes al cargo de administrador de la sociedad deudora declarada en quiebra; y se formula también, con carácter subsidiario de la acción anterior, la de responsabilidad solidaria por incumplimiento por los demandados de la obligación de disolución de la entidad deudora conforme al artículo $260.1,3 .^{\circ}$ y $4 .^{\circ}$ en relación con el artículo 262.5, de la misma LSA (...).

Frente a la argumentación de la sentencia recurrida, se formulan en el motivo diversas alegaciones que presentan una objeción insalvable para su examen casacional al incidir en el planteamiento de cuestiones procesales de carga de la prueba y de valoración probatoria, y otras de orden fáctico, que son impropias del recurso de casación, y que ya debieron haber determinado la inadmisión de este, y dan lugar ahora a su desestimación. Aparte de ello, y para agotar la respuesta judicial debe señalarse lo siguiente: a) La existencia del daño es una cuestión de hecho ajena al recurso de casación, sin que al amparo de los preceptos del enunciado quepa debatir acerca del tema relativo al alcance del convenio de la quiebra. b) Resulta incuestionable la existencia en el año 1997 de una situación de insolvencia definitiva de la sociedad, a la que contribuyeron los administradores con actos de descapitalización, y sin adoptar las decisiones legales exigibles, y en concreto la convocatoria de la junta general conforme a lo establecido en los arts. 260.1,4. ${ }^{\circ}$ y 262.2 de la Ley de Sociedades Anónimas. Por otra parte, en la resolución recurrida se recogen varias ilegalidades e irregularidades relativas a la contabilidad y a la llevanza de los libros de la entidad que demuestran la omisión de la diligencia exigible a todo administrador social. Y, c) finalmente, deviene indiscutible la existencia del nexo causal, por cuanto el daño cuya

${ }^{36}$ STS de 29 de julio de 2008, Recurso 1169/2002 (ponente CORBAL FERnÁNDEZ). 
indemnización se reclama en la demanda, consistente en el crédito que la entidad actora tenía con la entidad FRICUENCA, S.A., es una consecuencia de la situación de insolvencia de esta sociedad, a la que contribuyeron los administradores demandados y, además, no trataron de dar la salida de disolución del ente social conforme prevé la normativa legal. Por lo expuesto, se desestima el motivo, y el recurso, confirmándose la resolución recurrida y condenando a la parte recurrente al pago de las costas causadas, con arreglo a lo establecido en los arts.398.1 y 394.1 de la LEC (...).

c) Se argumenta que no existe obligación de los administradores de suscribir las acciones en la ampliación de capital, sin tener en cuenta que a los que se refiere, con toda la razón, la sentencia recurrida es al cumplimiento del acuerdo de ampliación -ejecución-, tanto más si se advierte que eran accionistas principales. d) Se señala que los administradores pueden renunciar cuando lo estimen oportuno, lo que es cierto, empero ello no impide que su marcha se pueda interpretar como un abandono de la empresa para rehuir responsabilidades dada la situación calamitosa de la misma...»

III $)^{37}$ «En el presente caso, no admite dudas que APARÁN S.A. ejercitó acción individual de responsabilidad contra los administradores de ACISA, amparándose por ende, no en la acción de responsabilidad objetiva de los artículos 262.5 en relación con el 260 del Texto Refundido de la Ley de Sociedades Anónimas, sino expresamente (páginas 12 y siguientes del escrito de demanda) en lo dispuesto en los artículos 135 y 133, en relación el deber de diligencia a que alude el artículo 127 del citado texto legal. Y es igualmente incuestionable que en la propia demanda se especifica que el acto indiligente generador de responsabilidad consistía exclusivamente en que las compras hechas por la sociedad se hicieron con la firme intención de no pagar el precio convenido, para lo cual se pactó que el vencimiento de la letra correspondiente a la primera venta tuviera lugar el 13 de febrero de 1993, dos días después del último pedido. En esta tesitura, la Sentencia de la Audiencia, lejos de incurrir en incongruencia, no hace sino responder exactamente a la controversia suscitada, ubicada en sede de responsabilidad por culpa, examinando si el demandante ha logrado acreditar, como le compete, tanto el concreto acto negligente que sirve de apoyo a su pretensión, como además, el vínculo causal entre este y el daño producido, acertando al revocar la sentencia apelada en la medida que, pasando por alto la falta de acreditación del acto indiligente imputado a los administradores, la sentencia de Primera Instancia basa su pronunciamiento estimatorio de la demanda en otros datos de hecho resultantes de la prueba practicada, que sí considera reveladores de una gestión negligente generadora de responsabilidad, hechos, y esto es lo importante, que no pueden sustentar la condena de los

${ }^{37}$ STS de 4 de junio de 2008, Recurso 1101/2001 (ponente AlmAGro NosETE). 
demandados en la medida que no fueron aducidos por el demandante como soporte fáctico de la acción ejercitada en su escrito de demanda, momento en que precluyó para él la posibilidad de apuntalar fácticamente la acción ejercitada-causa petendi-, dando la posibilidad a los demandados de alegar y probar lo contrario. En consecuencia, la Audiencia, consciente de la vinculación de la causa petendi, tal y como resultó configurada en la demanda, se limita a dilucidar si al adquirir las mercancías los gestores eran sabedores de la mala situación económica de la sociedad, decidiendo pese a ello ocultarla, y generar una apariencia de solvencia que determinara a la vendedora a seguir enviando los pedidos como si nada pasase, aun cuando desde octubre de 1992, fecha de la primera venta, se tenía la firme e inequívoca voluntad de no pagar el precio convenido, concluyendo la Sala de instancia, tras valorar la prueba libremente como le corresponde, que tal intención de sobreseer el cumplimiento de sus obligaciones no existió a priori, y por tanto, que no existe la actuación negligente que se reprocha a los demandados. A mayor abundamiento, soslaya la parte recurrente que la mera constatacion de la existencia de un comportamiento contrario a la Ley, a los estatutos o la diligencia exigible no es por sí generador de responsabilidad si no se prueba el enlace causal con el quebranto patrimonial sufrido por el acreedor, lo que tampoco ha quedado acreditado».

\section{IV $)^{38}$ «FUNDAMENTOS DE DERECHO}

PRIMERO. La cuestión litigiosa queda reducida en el recurso de casación objeto de enjuiciamiento a la responsabilidad individual de uno de los administradores sociales demandados -Don José Pedro-, porque los demás, también condenados por la Sentencia de la Audiencia, no formularon recurso.

El 10 de enero de 1996 Don Lucas dedujo demanda contra la sociedad INVERSIONES EDETANAS S.A., y Don José Pedro y tres personas físicas más, componentes todas ellas del Consejo de Administración de dicha entidad, así como también contra Doña Carmen, esposa del demandado Don Donato, a los solos efectos del artículo 144 del Reglamento Hipotecario, en la que interesa la condena solidaria al pago de la cantidad de veintiséis millones cuatrocientas cincuenta y dos mil seiscientas veintinueve pesetas (26.452.629 pts.), más los intereses legales desde la fecha de la interposición de la demanda. Se aduce como fundamento fáctico el impago de un pagaré librado por la representación de la sociedad demandada el 15 de octubre de 1995 por importe de 26.439 .409 pesetas, que produjo gastos de devolución ascendientes a la suma de 13.220 pesetas y el cierre de la empresa con desaparición de hecho de la sociedad de forma irregular e ilegal. Y se alega como fundamentación jurídica la doctrina jurisprudencial del levantamiento del

${ }^{38}$ STS de 30 de noviembre de 2005, Recurso 1117/1999 (ponente JESÚs CORBAL FERNÁNDEZ). 
velo y la normativa recogida en la Ley de Sociedades Anónimas en los artículos 127, 133 y 135 (acción de responsabilidad individual de los administradores sociales por lesión de los intereses de terceros) y $260.1,4 .^{\circ}$ y 262.5 (acción de responsabilidad solidaria de los administradores por obligaciones sociales).

\section{(...)}

TERCERO. En el segundo motivo se alega infracción de los artículos 127, 133, 134 y 135 de la Ley de Sociedades Anónimas, en relación con lo dispuesto en los artículos 260 y 262 de la misma Ley. En el cuerpo del motivo se alega: $1 .^{\circ}:$ Ausencia de la condición de administrador de la sociedad demandada por parte del recurrente Don José Pedro; 2..$^{\circ}$ : Ausencia de conducta activa u omisiva individualizada en la persona de Don José Pedro; $3 .^{\circ}$ : Ausencia de daño efectivo evaluable en la persona del actor Don Lucas; y,

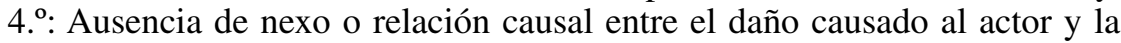
actuación de Don José Pedro, de acuerdo con el módulo establecido en el artículo 127 de la Ley de Sociedades Anónimas.

El motivo se desestima por las razones que se exponen a continuación y que se corresponden con el mismo orden expositivo del recurrente.

Mediante la alegación que constituye el primer punto del enunciado pretende el recurrente excluir su responsabilidad con el argumento de que si bien entró a formar parte del Consejo de Administración de la Sociedad en el mes de julio de 1991, sin embargo, un año después vendió las acciones y solicitó la baja del Consejo, de tal modo que su actuación fue absolutamente pasajera y testimonial, sin que tuviera en ningún momento capacidad alguna de decisión, no habiendo probado la actora que a la fecha de expedirse el pagaré continuara ostentando de forma efectiva el cargo de Secretario. La alegación carece de fundamento para poder tener eficacia exculpatoria porque el Sr. José Pedro fue designado Secretario del Consejo de Administración en Junta Universal celebrada el 14 de marzo de 1991, cuyos acuerdos se formalizaron en la escritura pública del 2 de mayo, inscrita en el Registro Mercantil el 26 de julio, y tal cargo continúa vigente. Si el Sr. José Pedro hubiera querido renunciar lo habría hecho como lo hizo otro Consejero según consta en la inscripción quinta (folio 69 vuelto de autos), el cual no fue demandado. Por otro lado debe resaltarse que en la resolución recurrida no hay base probatoria alguna que permita sustentar que el Sr. José Pedro se había desconectado de las actuaciones del Consejo, y era a él a quien le correspondía acreditar tal afirmación de conformidad con la normativa general del onus probandi y lo establecido en el artículo 133.2. de la Ley de Sociedades Anónimas. Y finalmente no es conforme al normal discurrir de las cosas, ni propio de un comportamiento diligente, en relación en concreto con el ámbito societario mercantil, y concurriendo circunstancias como las de la Sociedad de que se trata y un evento de la entidad del contemplado en autos -expedición a cargo de la entidad de un pagaré de más de veintiséis millones de pesetas-, permanecer pasivo, cuando legalmente se ostenta el 
cargo de Secretario del Consejo de Administración, por lo que resulta lógico entender que el libramiento del efecto respondió -como además declara probado la Sentencia recurrida - al cumplimiento de una deuda contraída en beneficio de la Sociedad.

En el segundo punto del enunciado se argumenta que desde que vendió las acciones, el recurrente, abandonó "de facto" la sociedad y estaba convencido de que había sido sustituido en el cargo de Consejero, añadiendo que no conocía al actor, ni la existencia del pagaré, ni la relación subyacente que, al menos en teoría, debió dar lugar al mismo. La alegación resulta fácticamente inconsistente porque en la resolución impugnada no hay base que permita sustentarla, ni es posible configurarla en casación con fundamento en los preceptos del enunciado. Por otro lado, debe señalarse que no hay nada de extraño en que el pagaré haya sido librado por la persona del Consejo que tenía poder para ello; y no resulta explicable "la confianza" a que alude el recurrente habida cuenta las circunstancias concurrentes en la sociedad, las cuales se exponen ampliamente en el párrafo tercero del fundamento tercero de la resolución recurrida, y de las que se deduce la existencia de dificultades económicas, que condujeron posteriormente a la venta de los bienes inmuebles a terceras personas, y el cese de la actividad económica con abandono del domicilio social.

En el punto tercero del enunciado se alega ausencia de daño efectivo evaluable en la persona del actor. El planteamiento se rechaza porque incurre en el defecto casacional de hacer supuesto de la cuestión, es decir, prescinde de la apreciación fáctica de la resolución recurrida sin haberla desvirtuado por el cauce adecuado. Claramente se estima por el juzgador a quo que el pagaré tenía por objeto devolver al demandante la suma de dinero que este había entregado a la mercantil en concepto de préstamo o de sociedad, y asimismo se razona acerca del impago del efecto y la imposibilidad de realizarlo por desaparición de la empresa y la inexistencia de bienes.

Y por lo que respecta al punto cuarto, en el que se niega el nexo causal entre el daño causado y la actuación de Don José Pedro, de acuerdo con el módulo establecido en el artículo 127 de la Ley de Sociedades Anónimas, argumentando que el recurrente no firmó el pagaré, sino que lo hizo la única persona apoderada por la sociedad demandada -Don Donato-, que es quien, en exclusiva -se añade- debería responder de su suscripción, por ser ella la que conoce las razones que le impulsaron a la expedición, también se rechaza. Y ello es así porque si, por un lado, se vuelve a hacer hincapié en apreciaciones fácticas contrarias a las de la resolución recurrida, sin tener en cuenta que devinieron incólumes y vinculantes en casación, como la relativa a la realidad del contrato subyacente y el destino del pagaré (para cancelar una deuda existente), por otro lado resulta asimismo incuestionable que el Sr. Donato estaba legalmente facultado para librar el título mercantil en nombre de la sociedad. Finalmente, y como respuesta a todos los puntos del enunciado debe resaltarse que, aun cuando el Sr. José Pedro vendió las accio- 
nes de la sociedad INVERSIONES EDETANAS S.A. el 3 de mayo de 1992, no por ello dejó de ser Consejero y Secretario del Consejo de Administración, pero es que, además, la deuda con el Sr. Lucas se generó en el año 1991 en virtud de una inversión realizada por este, tal y como declara probada la resolución recurrida en relación con los folios 204, 634 y 635 de autos.

Por todo ello, es innegable que concurren los requisitos para que prospere la acción individual de responsabilidad del artículo 135 de la Ley de Sociedades Anónimas, consistente, en el caso, en un comportamiento, cuando menos omisivo, contrario a la ley y sin la diligencia de un ordenado comerciante, causante de una lesión concreta a los intereses de un tercero (acreedor de la sociedad), existiendo una relación causal directa entre tal comportamiento y el daño (Sentencias, entre otras, 27 de octubre y 7 de diciembre de 2004 y 25 de abril, 26 de mayo y 20 de junio de 2005); aparte de que la resolución recurrida condena también a los codemandados personas físicas con base en los artículos 260.1, 4. ${ }^{a}$ y 262. 5 de Ley de Sociedades Anónimas, sobre responsabilidad solidaria por obligaciones sociales -cuya acción se ejercitó acumuladamente en la demanda-, razonando de modo acertado en el último párrafo del fundamento cuarto acerca de la concurrencia de los presupuestos que condicionan el pronunciamiento, los cuales se ajustan al supuesto normativo y a la doctrina de este Tribunal (Sentencias de 16 diciembre de 2004 y 23 de septiembre y 17 de octubre de 2005, entre las más recientes), pues resulta incuestionable que la sociedad INVERSIONES EDETANAS S.A. cesó en su actividad en el tráfico mercantil abandonando el inmueble en que tenía radicada la sede social, carece de patrimonio conocido para hacer frente al crédito del actor, y procedió a desprenderse de sus bienes inmuebles sin observar ningún procedimiento para la correcta liquidación de los mismos y atender a las obligaciones contraídas, lo que supone un cierre de la empresa, o desaparición de hecho, irregular e ilegal, que acarrea la consecuencia económica negativa para los administradores sociales prevista en el artículo 262.1 y 5 en relación con el 2601 1, 4. ${ }^{\circ}$ de la Ley de Sociedades Anónimas».

V) ${ }^{39}$ El administrador no está exonerado en ninguna circunstancia de las responsabilidades anejas a las funciones esenciales del cargo.

«FUNDAMENTOS DE DERECHO (...).

TERCERO.- Dedica la mercantil recurrente el último motivo (quinto) a aportar aplicación de los artículos 113, 133 y 134 de la Ley de Sociedades Anónimas, para plantear la cuestión de la acción social de responsabilidad, la que no se integró expresamente en el suplico de la demanda, pero la sen-

${ }^{39}$ STS de 24 de noviembre de 2005, Recurso 966/1999 (ponente AlFONSO ViLLAGÓMEZ RodiL). 
tencia de apelación la consideró y resolvió para decretar su improcedencia en base al hecho que declara probado que había desaparecido el capital social, pues el lugar donde la sociedad realizaba su actividad de comercialización de flores y plantas -artículo 2..$^{\circ}$ de los Estatutos-, sufrió intensas inundaciones en el año 1986, que ocasionaron perjuicios por importe de 14.898.365 pesetas y la desaparición prácticamente de la compañía como operativa.

Se atribuye actuación responsable al administrador en relación a las indemnizaciones que la empresa pudo percibir por dicho siniestro, pretensión que el Tribunal de Apelación no acogió, ya que, por una parte, no resultó probado que los daños causados se debieran a actuación negligente de persona alguna que pudiera responder de los mismos y menos del demandado, así como tampoco resultó demostrado que el ejercicio de las posibles acciones hubiera podido generar alguna clase de ingreso económico a favor de la sociedad, estableciendo la sentencia recurrida las actuaciones iniciales llevadas a cabo, lo que disipa la concurrencia de situación de pasividad e inactividad total.

El artículo 134 de la Ley de Sociedades Anónimas contempla la acción social de responsabilidad -de aplicación a las sociedades de responsabilidad limitada, conforme al artículo 11 de la Ley de 25 de Julio de 1989- y su ejercicio requiere el presupuesto previo y básico de que los administradores hubieran causado daño a la sociedad por haber llevado a cabo actos contrarios a la Ley o a los Estatutos o sin la diligencia necesaria con la que deben desempeñar el cargo (art. 133), lo que no se acreditó. A su vez resulta preciso que en Junta General se decide el ejercicio de la referida acción y aquí sucede que en la Junta Universal celebrada el 15 de marzo de 1995, con intervención del socio don Óscar (representado) y el liquidador, se acordó en el apartado B) que el liquidador estaba igualmente y expresamente autorizado a formular reclamación de daños y reivindicación de bienes contra el mencionado administrador, así como formular denuncia o querella contra el mismo (apartado A). En ningún momento en dicha Junta se hizo constar acuerdo expreso sobre el ejercicio de la responsabilidad social estudiada en cuanto a la pasividad plena que se atribuye al demandado, o por cualquier otra conducta generadora de posible responsabilidad frente a la sociedad.

El motivo se rechaza. En todo caso la sentencia recurrida es terminante al declarar que no existe ninguna prueba de que el administrador con la pasividad que se le imputa quisiera perjudicar a la compañía o que hubiera incumplimiento determinante por su parte, no dándose nexo causal entre la conducta de aquel y la omisión en el ejercicio de sus derechos frente a terceros para poder ser declarado responsable.

CUARTO.- Se lleva a cabo en el motivo primero aportación de aplicación del artículo 171 y de los siguientes del Código de Comercio (defectuosa técnica casacional), ya que en el suplico de la demanda se integró la petición de que el demandado (apartado A) debía rendir cuentas de su gestión 
como administrador de la Sociedad actora desde su nombramiento. La sentencia recurrida desestimó tal petición con la escueta declaración que dice: "Pero ya en la fase de liquidación no se puede pedir que rinda cuentas de su gestión como administrador de los bienes de la sociedad desde el nombramiento en el acto constitucional, máxime cuando nunca se hizo desde que nació la sociedad de capital".

Tal conclusión decisoria no se puede aceptar por conculcar la legalidad de aplicación y así el artículo 267 de la Ley de Sociedades Anónimas declara que desde el momento en que las sociedades se declaran en liquidación, cesará la representación de los administrados, los que deberán prestar su colaboración para las operaciones liquidatorias si fueran requeridos al efecto. El administrador en ningún momento queda liberado de dar rendición de las cuentas anteriores a la apertura de la liquidación y así lo disponen los artículos 171 y 172 de la Ley de Sociedades Anónimas, en relación al artículo 34 y concordantes del Código de Comercio, así como 17 y 18 de los Estatutos Sociales y artículos 13 y 26 de la Ley de Sociedades de Responsabilidad Limitada, según redacción de la Ley 19/1989.

El motivo ha de ser estimado. La rendición de cuentas y gestión administradora se integra en el área competencial propia de los administradores sociales válidamente nombrados, tratándose de funciones de las que son exclusivos depositarios e inherentes al cargo, siendo actividad de su propia iniciativa por acatamiento de lo dispuesto en la Ley, de la que no les exonera y menos puede justificar el que la sociedad no hubiera exigido la referida rendición, como bien pudo hacerlo, como tampoco el hecho posterior de entrar en liquidación (Junta Universal de 15 de marzo de 1995).

No cabe atender la alegación impugnatoria que presenta el recurrido de que el demandado era solo administrador nominal, ya que la contabilidad y documentación de la compañía era llevada por otra persona de la confianza del otro socio señor Óscar. Efectivamente en el ámbito societario puede aparecer la figura del administrador de hecho, que actúa como verdadero gestor social, requiriéndose para poder apreciar estas situaciones irregulares y ocultas, a efectos de establecer las consecuentes responsabilidades en aras de los principios de la buena fe mercantil o de protección de las apariencias, la necesaria prueba, si bien es cierto que la directa en la mayoría de los casos resultará imposible, por lo que el camino procesal mas apto es la prueba indiciaria, a la que para nada se refiere la sentencia de apelación.

$\mathrm{Al}$ acogerse el motivo corresponde a esta Sala por aplicación del artículo 1715-1-3. ${ }^{\circ}$ de la Ley Procesal Civil, resolver lo que corresponda, dentro de los términos del debate procesal promovido, lo que nos lleva a decidir que la sentencia de apelación ha de anularse, en cuanto se estima la petición de la recurrente de que el demandado don Ángel Daniel debe rendir cuentas de su gestión como administrador de la compañía, desde que fue nombrado para el cargo en la escritura fundacional de 15 de octubre de 1989 (cláusula tercera) hasta el cese en su condición de socio, por exclusión de la sociedad, 
que decretó la sentencia firme de la Audiencia Provincial de Granada el 31 de Mayo de 1994 (Sección cuarta, rollo de apelación 516/93)».

V) ${ }^{40}$ Diligencia del administrador y condiciones para la prosperabilidad de la acción de responsabilidad individual que se dirija contra él. «FUNDAMENTOS DE DERECHO.

QUINTO.- Finalmente, los motivos segundo y cuarto (artículo 1.692-4. ${ }^{\circ}$ de la Ley de Enjuiciamiento Civil expresada) se examinan conjuntamente, dada la estrecha relación que entre ellos existen, pues ambos se refieren a la responsabilidad individual del administrador social Don Ricardo, uno, mediante la invocación, como infringidos, de los artículos 133 y 135 de la Ley de Sociedades Anónimas; y, otro, al aducir que, en todo caso, por aplicación del artículo 1.968-2. ${ }^{\circ}$, la hipotética responsabilidad habría prescrito. En lo que concierne a la cuestión de la responsabilidad individual o personal del administrador, ha de estimarse que este tipo de responsabilidad ex lege, procede por la conducta del administrador en el ejercicio de su cargo, cuando la misma se manifiesta en actos u omisiones negligentes o culposos productores de daños, según un razonable nexo causal. Esto es, los datos fácticos tienen que producir la verificación de una lesión concreta, la determinación precisa de unos actos u omisiones que conduzcan a considerar que la actuación del administrador no fue adecuada con la diligencia ordenada de un comerciante, $y$, por ello culposa, todo ello en correlación causal con el daño habido. Los elementos fácticos que se establecen, como probados, en ambas sentencias de instancia, no permiten construir, por insuficiencia, el supuesto de hecho normativo imputable al administrador para exigir la responsabilidad. En efecto, la sentencia recurrida se limita a consignar que "si el propio administrador reconoce en confesión que a lo largo de estos años no se ha pagado cantidad alguna de la deuda contraída, el calificativo más benévolo es el de negligente, lo que desencadena su responsabilidad como nos recuerda, entre otras análogas, la sentencia del Tribunal Supremo de 13 de febrero de 1990". Tal sentencia, sin embargo, no se refiere a un caso similar o idéntico al presente. Tampoco, la sentencia de primera instancia, en la que la de segunda se apoya es muy explícita sobre el particular al consignar que "el administrador deberá ser igualmente condenado, por cuanto al encontrarse al frente de la sociedad y corresponderle supervisar el giro o tráfico de la misma, evitando eventuales daños a terceros que pudieran derivarse de la actividad de la mercantil, asume la responsabilidad de dicha gestión. La cuestión relativa a la prescripción ya fue examinada en sentido desestimatorio. En consecuencia, procede acoger el motivo, sin que el otro motivo citado tenga utilidad en función de la estimación del indicado (...)”».

${ }^{40}$ STS de 25 de abril de 2005, Recurso 4197/1998 (ponente AlMAGRo NOSETE). 


\section{$2 .{ }^{41}$ Buena fe (fidelidad) y retribución del administrador}

«El debate estuvo motivado por el significado que atribuye al silencio de los estatutos sociales, sobre si el cargo de administrador es o no retribuido, el artículo 66.1 de la Ley 2/1995, de 23 de marzo, de sociedades de responsabilidad limitada, a cuyo tenor es gratuito a menos que los estatutos establezcan lo contrario, determinando el sistema de retribución.

En la demanda un socio, D. Luis Antonio, negó que el administrador demandado tuviera derecho a la retribución contractual que durante años, había percibido y, mediante el ejercicio de la acción social de responsabilidad, que regulan los artículos 69 de la Ley 2/1995 y 134 del Texto refundido de la Ley de Sociedades de Anónimas -Real Decreto Legislativo 1.564/1989, de 22 de diciembre-, pretendió que fuera condenado a indemnizar a la sociedad por el daño causado en medida igual al sueldo recibido con causa en un contrato de febrero de mil novecientos noventa y uno. Y, como la fuente de las retribuciones había sido el mencionado contrato, el socio demandante consideró que debía obtener previamente, y así lo pretendió, la declaración judicial de su nulidad por contravenir lo dispuesto en el artículo 67 de la Ley 2/1995, a cuyo tenor el establecimiento de cualquier clase de relación de prestación de servicios entre la sociedad y el administrador requiere acuerdo de la junta general.

El Juzgado de Primera Instancia estimó la demanda y la Audiencia Provincial desestimó el recurso de apelación que había interpuesto el demandado. (...)

OCTAVO. Los demás motivos del recurso se refieren, directa o indirectamente, a la compatibilidad de la retribución percibida, como personal de alta dirección, por el administrador único de una sociedad de responsabilidad limitada, con el carácter gratuito de este cargo social -a la vista de los estatutos y del artículo 66 de la Ley 2/1995- y a la significación jurídica que corresponda atribuir al comportamiento del demandante, que toleró durante años que el administrador demandado percibiera la remuneración sin protesta conocida.

Sobre la primera cuestión, la jurisprudencia ha ido perfilando en los últimos tiempos una doctrina contraria a la posibilidad de que la retribución del administrador de las sociedades de capital se sustraiga a la transparencia exigida en los artículos 130 del Real Decreto legislativo 1.564/1989 y 66 de la Ley 2/1995, por el expediente de crear un título contractual de servicios de alta dirección con causa onerosa, en tanto no sea posible deslindar esa prestación de la debida a la sociedad por el administrador en el funcionamiento de la relación societaria. Para admitir la dualidad de regímenes jurídicos de la retribución, uno contractual y otro estatutario, esto es, para no aplicar el

${ }^{41}$ STS de 29 de mayo de 2008, Recurso 322/2002 (ponente FERRÁNDIZ GABRIEL). 
establecido en la legislación de las sociedades de capital a la retribución convenida a favor del administrador como alto cargo, las sentencias de 5 de marzo de 2004 y 21 de abril de 2005 exigieron la concurrencia de un elemento objetivo de distinción entre las actividades debidas por una y otra causa.

La sentencia de 24 de abril de 2007 precisó que, para que el régimen estatutario de la retribución de los administradores pueda ser eludido con un contrato, es necesario que las facultades y funciones atribuidas en él al administrador rebasen las propias de los administradores, ya que "admitir otra cosa significaría la burla del mandato contenido en el artículo 130, mediante el rodeo propio del fraus legis".

Lo mismo declaró la sentencia de 31 de octubre de 2007, con el argumento de que, "de otro modo, el contrato de alta dirección no sería más que una forma de encubrir la remuneración como consejero, sin estar prevista en los estatutos".

Esa doctrina, favorable al tratamiento unitario de lo que constituye un aspecto esencial de la administración social y del funcionamiento de la sociedad, se inspira en la conveniencia de hacer efectivo el control de los socios sobre la política de retribución de los administradores, mediante una imagen clara y completa de ella -incluidos los contratos de empleo suscritos por los mismos con la sociedad-y responde, además, a los términos del artículo 1.3.c) del Estatuto de los Trabajadores -Real Decreto Legislativo 1/1995, de 24 de marzo-, que excluye de su ámbito la actividad que se limite, pura y simplemente, al mero desempeño del cargo de consejero o miembro de los órganos de administración en las empresas que revistan la forma jurídica de sociedad y siempre que su actividad en la empresa solo comporte la realización de cometidos inherentes a tal cargo.

Tratándose de sociedades de responsabilidad limitada, como es el caso, la referida doctrina no es contraria a los términos del artículo 67 de la Ley 2/1995, que considera bastante el acuerdo de la junta general para el establecimiento o modificación de cualquier clase de relaciones de prestación de servicios o de obra entre sociedad y administrador, ya que dicho precepto ha de ser interpretado en relación con los antes indicados.

Por lo expuesto, no cabe mas que desestimar el motivo sexto del recurso, en que el demandado señala como infringidos los artículos 133 y $134 \mathrm{del}$ texto refundido de la Ley de Sociedades Anónimas -se entiende, en relación con el artículo 69 de la Ley 2/1995-, con el argumento de que no causó daño a la sociedad por haber percibido la retribución como contraprestación por los servicios a ella prestados efectivamente. Y la razón de la desestimación no es otra que la resultante de que la actividad retribuida como laboral especial fuera la misma debida por el recurrente, como administrador, sin derecho a ser remunerado. De manera que el daño causado a la sociedad fue, justamente, la retribución obtenida sin causa.

NOVENO. En el motivo octavo plantea el recurrente la segunda cuestión que quedó al principio apuntada. Afirma que la sentencia recurrida había 
desconocido la jurisprudencia sobre la inadmisibilidad de un comportamiento contrario a los llamados actos propios, por no haber tomado en consideración que la sociedad por él administrada estaba integrada solo por dos socios -él y el demandante-, así como que había percibido la retribución como gerente casi desde el comienzo de las operaciones sociales y que el actor, con pleno conocimiento, había votado a favor de la aprobación de las cuentas anuales correspondientes a los ejercicios de cinco años, antes de reclamarle la devolución de lo que, en tal concepto, había recibido.

Este motivo, tal como ha sido formulado, no permite examinar si, realmente, demandante y demandado alcanzaron un acuerdo, expresa o tácitamente, para que el segundo percibiera de la sociedad un sueldo -lo que posiblemente sería lógico suponer-. Pero, en todo caso, tiene una base fáctica constituida por unos datos examinados en la instancia -el demandado sostuvo la validez del contrato de alta dirección, en último término por haber caducado la acción de nulidad-, que se relacionan directamente con la verdadera razón que justifica la doctrina que antes quedó expuesta, esto es, la conveniencia de proporcionar a los socios la oportunidad de analizar la política de retribuciones a partir de una información completa.

Dos circunstancias ofrecen las actuaciones verdaderamente significativas y determinantes de la estimación del motivo.

Por un lado, el que los socios integrantes de la sociedad fueran solo dos, el demandante y el administrador demandado, convierte en difícil de imaginar un desconocimiento por el primero de los detalles importantes de la gestión social dirigida por el segundo, entre ellos, el relativo a la política de retribuciones - un dato similar fue tomado en consideración en la sentencia de 31 de octubre de 2007-.

Por otro lado, el demandante, como se ha dicho, conocedor -cuanto menos, al aprobar las cuentas de los respectivos ejercicios- de que el administrador social percibía un sueldo como gerente, respondió ante esa evidencia con un comportamiento tolerante, no en una ocasión, sino durante varios ejercicios: los correspondientes a los años mil novecientos noventa y uno a mil novecientos noventa y cinco -supuesto distinto, por esa continuidad, al contemplado en la sentencia de 24 de abril de 2007-.

Con tales antecedentes la mencionada conducta merece ser calificada como apta para generar fundadamente en el otro socio la confianza en una coherencia futura sobre tal cuestión y, por ello, en que podía seguir percibiendo la remuneración por haber sido admitida por quien era titular de la otra mitad de las participaciones sociales. Es decir que, además de que la sociedad estaba de acuerdo al estarlo todos los integrantes de la junta general, el otro socio no le iba a reclamar devoluciones. Y aunque en la demanda solo se reclaman las cantidades percibidas por el demandado, como sueldo, en los ejercicios siguientes, el comportamiento descrito, en cuanto significativo, prolongado y contradictorio con la pretensión deducida en la demanda, convierte a esta en inadmisible, en aplicación del principio gene- 
ral de buena fe, en el sentido de modelo de conducta, que actúa en su función de límite del ejercicio de los derechos subjetivos -adversus factum suum quis venire non potest-, como la jurisprudencia ha reiterado -sentencias de 1 y 20 de diciembre de 2006 y 17 de julio de 2007, entre otras-. No se oponen a la aplicación de ese límite los artículos 133.3 y 134.3 del texto refundido de la Ley de Sociedades Anónimas -en relación con el artículo 69 de la Ley 2/1995-, porque no se atribuye eficacia exoneradora a los acuerdos sociales de aprobación de las cuentas anuales, sino que se valora el comportamiento del socio demandante, reiterado durante varios ejercicios, como generador de confianza en el demandado sobre la regularidad de la percepción de su sueldo».

\section{Sobre competencia desleal del administrador}

I ${ }^{42}$ En la sentencia que se reproduce seguidamente se analiza el deber de lealtad del administrador. Además, concluye estableciendo doctrina legal sobre la prohibición de competencia desleal.

«FUNDAMENTOS DE DERECHO

PRIMERO. Resumen de antecedentes.

1. Un socio interpuso demanda solicitando que se declarase la nulidad del acuerdo de 25 de junio de 1999, en el que se acordaba la continuidad de dos personas en su condición de administradores de la sociedad limitada, por haber incurrido en competencia desleal.

2. Los demandados alegaron que no concurren en el presente caso las causas legales de cese en la condición de administrador previstas en el artículo 65 LSRL ( «1. Los administradores no podrán dedicarse, por cuenta propia o ajena, al mismo, análogo o complementario género de actividad que constituya el objeto social, salvo autorización expresa de la sociedad, mediante acuerdo de la Junta General. 2. Cualquier socio podrá solicitar del Juez de Primera Instancia del domicilio social el cese del administrador que haya infringido la prohibición anterior»), ya que, si bien reconocían que habían llevado a cabo la creación de una sociedad con el mismo objeto que la codemandada, de la que eran administradores, esta sociedad no llegó a realizar actividad alguna.

3. La sentencia de primera instancia estimó la demanda por considerar que no es preciso que se acredite que se ha producido un perjuicio efectivo a la sociedad, sino que basta con que se dé un eventual conflicto de intereses; y que la situación prevista en el artículo 65 LSRL debe darse en el momento en el que se adopte el acuerdo social, por lo que resulta indiferente que la sociedad fuera disuelta el 22 de julio de 1999, es decir, poco después de la adopción del acuerdo social impugnado.

\footnotetext{
${ }^{42}$ STS de 5 de diciembre de 2008, Recurso 1353/2003 (ponente XIOL Ríos).
} 
4. La Audiencia Provincial revocó esta sentencia y desestimó la demanda por considerar, en síntesis, que la falta de actividad, a excepción de la constitución de la sociedad, impide la consideración de que en el momento de la demanda los demandados se encontraran incursos en la prohibición; que la sociedad estaba liquidada a la fecha de la demanda y que la parte demandante no accionó con anterioridad conforme le faculta el artículo 65.2 $L S R L$, por lo que resulta indiferente la solicitud judicial de Junta.

5. Contra esta sentencia interpone recurso de casación la parte demandante, cuyo único motivo ha sido admitido por interés casacional (...).

El recurso debe ser estimado (...).

TERCERO. La infracción de la prohibición de competencia desleal a los socios-administradores en las sociedades de responsabilidad limitada por constitución de una sociedad con idéntico objeto.

El artículo 65 LSRL, que exige la lealtad en el ejercicio del cargo de administrador (reforzado por la llamada Ley de Transparencia: Ley 26/2003, de 17 de julio, y STS 21 de julio de 2006, rec. 4654/1999) impone a los administradores, como obligación negativa, la prohibición de concurrencia, que solo cesará cuando la Junta general, conociendo las actividades competitivas del administrador, autorice expresamente a ejercerlas, por lo que incurre en su vulneración el administrador que sin tener la autorización requerida vulnera la prohibición; y se ajusta a esta regla el acuerdo de la junta general que ordena su cese (STS 11 de abril de 2007, rec. 2172/2000).

La prohibición del artículo 65 LSRL, fundada en la existencia de una incompatibilidad, tiene su fundamento en el sustrato ético que debe presidir las relaciones económicas, por lo que se impone una interpretación rigurosa del precepto (STS 9 de septiembre de 1998, rec. 549/1994), pues la Ley ha querido revestir de un especial rigor a esta prohibición, de manera que su infracción autoriza la expulsión del socio-administrador (STS de 6 de marzo de 2000). La normativa legal se inspira en el daño que pueda sufrir la sociedad, el cual ha de tratarse de un riesgo serio y consistente que puede ser actual o potencial y no exige la demostración de un beneficio efectivo en otras empresas o en otras personas (STS 12 de junio de 2008, rec. 1136/2001). En consecuencia con esta doctrina, este tribunal tiene declarado que el hecho de que al tiempo de acordarse la exclusión de la sociedad no fuera la administradora la recurrente no excluye la aplicación del precepto, pues no exige la actualidad en el cargo (STS 26 de enero de 2006, rec. 2230/1999) y se registran ejemplos en nuestra jurisprudencia que estiman acreditada una actuación de deslealtad cifrada en la prohibición de concurrencia por la constitución de una sociedad con idéntico objeto (SSTS 1 de octubre de 1986, 7 de noviembre de 1986, 19 de abril de 2004, rec. 1769/1998), considerada como acto de efectiva concurrencia «aun cuando desafortunadamente, la sociedad constituida no pudo adjudicarse proyecto alguno» (STS 6 de marzo de 2000, rec. 1515/1995), de donde se infiere que el daño que origina la actividad competitiva no se funda en su carácter actual y efectivo, 
sino en que sea real y consistente y se origine por una contraposición de intereses, valorada a tenor de las circunstancias del caso (STS de 28 de junio de 1982). Hay que estimar que la doctrina recogida en estas sentencias, que responden a la línea jurisprudencial de la que son reflejo las citadas como contradichas por la parte recurrente, está en contradicción con la posición de la sentencia recurrida, en cuanto estima que la mera constitución de una sociedad con idéntico objeto no implica una actitud competitiva si no se demuestra que esta desarrolla una actividad efectiva y se ha disuelto con anterioridad a la presentación de la demanda, y no niega la existencia de la contraposición de intereses que el Juzgado de Primera Instancia estima probada. En resolución, procede fijar como doctrina jurisprudencial que la prohibición de competencia desleal que impone a los administradores el artículo 65 LSRL se infringe mediante la creación por parte de estos, sin la autorización expresa de la sociedad, de una sociedad con idéntico objeto, salvo que se demuestre, valorando las circunstancias, que no existe contraposición de intereses (...).

4. Se fija como doctrina jurisprudencial que la prohibición de competencia desleal que impone a los administradores el artículo $65 \mathrm{LSRL}$ se infringe mediante la creación por parte de estos, sin la autorización de la sociedad, de una sociedad con idéntico objeto, salvo que se demuestre, valorando las circunstancias, que no existe contraposición de intereses».

B. Sobre RESPonsabilidAd obJeTIVA (o "CUASI" obJetiva) DE LOS ADMINISTRADORES POR LA SOBLIGACIONES CONTRAIDAS CON POSTERIORIDAD AL ACAECIMIENTO DE LA CAUSA LEGAL DE DISOLUCIÓN, PREVISTA EN LOS ARTÍCULOS 262.5 DE LA L.S.A. Y 105.5 L.S.R.L. POR NO PROMOVER LA DISOLUCIÓN DE LA COMPAÑÍA EN EL PLAZO QUE LA LEY ESTABLECE

Constituyen estas sentencias el grupo más numeroso.

I $)^{43}$ El art. 262.5 de la L.S.A. tiene la finalidad de proteger a los acreedores de la sociedad, evitando la desaparición total de su patrimonio.

«FUNDAMENTOS DE DERECHO.

PRIMERO.- El presente recurso trae causa de la demanda formulada por "Sociedad Anónima El Águila" contra "H. BOSCH, S.A.", en reclamación de la suma de 41.544.762 pts., y contra D. Juan María, a quien, en su calidad de administrador de "H. Bosch", interesaba fuera condenado solidariamente al pago de la citada cantidad y de otras que habían sido exigidas a la mencionada mercantil en otros procesos, totalizando 128.003 .514 pts.

${ }^{43}$ STS de 23 de septiembre de 2005, Recurso 1210/1999 (ponente ANTONIO Romero LORENZO). 
Los demandados mostraron oposición a las pretensiones deducidas y " $\mathrm{H}$. Bosch" formuló además reconvención, solicitando se declarase que la actora le había causado daños y perjuicios por incumplimiento del contrato de distribución exclusiva de cerveza en botella y lata, en determinadas localidades de la provincia de Valencia, celebrado entre ambas sociedades el 5 de mayo de 1981, por un plazo de diez años, por lo que debía ser condenada al pago de la cantidad que en tal concepto se determinase. El Juzgado de Primera Instancia acogió la demanda y declaró la responsabilidad solidaria del $\mathrm{Sr}$. Juan María por las deudas que "H. Bosch" mantenía con la actora, que ascendían a 128.003 .514 pts., condenando solidariamente a ambos demandados, con imposición de costas a abonar a aquella 41.544 .762 pts. más los intereses legales devengados desde la presentación de la demanda, en cuanto a "H. Bosch". Por otra parte, absolvió a "S.A. El Águila" de las peticiones de la demanda reconvencional. En fase de apelación, la Audiencia Provincial absolvió al Sr. Juan María del pedimento relativo a su responsabilidad por la suma de 86.458 .752 pts. y mantuvo los demás pronunciamientos de la sentencia recurrida, salvo el relativo a las costas de la demanda, de las que no hizo condena, manteniendo la imposición a "H. Bosch" de las de la reconvención, y sin hacer especial declaración respecto a las de la alzada.

\section{(...)}

Aparte de ello, ha de afirmarse, ante todo, que la posición que un administrador social ocupa en la entidad cuya gestión y representación le ha sido encomendada y que debe desempeñar con la diligencia que establece el artículo 127,1 de la L.S.A., determina que el mismo haya de conocer puntualmente cuando la evolución económica de aquella impone llevar a cabo la reducción de su capital, por haber descendido por debajo del nivel que fija el artículo 163.1 del citado texto legal, o, incluso, promover la liquidación de la sociedad, conducta esta última que según la Audiencia era la procedente en el caso que nos ocupa, y cuya omisión es lo que ha motivado el parcial acogimiento de la pretensión deducida contra el recurrente.

En tal contexto, ha de observarse que para llegar a su decisión, la Audiencia Provincial ha ponderado que en 1992 las cuentas anuales presentadas al Registro Mercantil por la entidad demandada ya reflejaban una cifra negativa de 85.171 .473 pts. cantidad que en el ejercicio siguiente se elevó a 107.603.104 pts., dando lugar a una situación que la propia entidad demandada en un dossier elaborado a finales de 1993 calificaba de caótica, teniendo en cuenta que el capital social era únicamente de17.000.000 de pesetas, sin que en dicho documento se hiciese referencia alguna que en dicha realidad contable hubiese influido la actuación de "El Águila".

A ello añade el Tribunal de instancia que no puede hablarse de abuso de derecho imputable a la actora, por cuanto, a pesar de todo, se continuó por la misma el suministro de mercancías, hasta finales del año 1994.

De cuanto acaba de exponerse se desprende que necesariamente ha de calificarse de correcta la conclusión a que se llega en la sentencia recurrida 
respecto a que en el supuesto de litis indudablemente concurría la causa legal de disolución del artículo 260.4 L.S.A., que obligaba al administrador a convocar Junta General en plazo de dos meses para la adopción del correspondiente acuerdo, lo que comporta la declaración de responsabilidad solidaria de los administradores por las obligaciones sociales, según consolidada doctrina de esta Sala (sentencias de 20 de febrero, 1 de marzo, 7 y 14 de mayo y 5 y 6 de octubre de 2004, por citar únicamente las más recientes.»

I bis $)^{44}$ De nuevo sobre la finalidad de la responsabilidad ex art. 262.5 L.S.A.

«4. a.- Lo que se desprende de los hechos probados es que a finales de 1993 se decidió poner fin a la empresa y desguazar sus dos únicos buques para obtener la correspondiente subvención oficial, cuyo importe se dedicó a aquello que se consideró más oportuno para, finalmente, acabar desapareciendo de hecho la sociedad. Por tanto, se produjo aquello que precisamente los arts. 260 y 265 LSA tratan de evitar cuando imponen a los administradores unos deberes orientados a una extinción de la sociedad ordenada por etapas y que preserve adecuadamente los derechos tanto de los socios como de los terceros, sin que los administradores puedan decidir por su cuenta qué terceros verán total o parcialmente satisfechos sus créditos y cuáles no.

5. a- Por último, el motivo desconoce que la demanda se fundaba también en el ordinal $3 .^{\circ}$ del art. 260.1 LSA, y evidente resulta que la decisión de desguazar los dos únicos buques de la empresa, sin previsión de sustitución alguna, implicaba una imposibilidad de realizar el fin social tan manifiesta que los hechos posteriores no vinieron sino a corroborarla por completo».

I ter ${ }^{45}$ Sentencia igualmente relativa a la finalidad del art. 262.5 L.S.A. «PRIMERO.

1) El Juzgado condenó a los demandados, D. ${ }^{a}$ Celestina y D. Federico, en aplicación del artículo 262.5 de la Ley de Sociedades Anónimas [LSA], como administradores de Construcciones y Contratas Melsio, S. A., al pago de 9.210.260 ptas., e intereses legales desde la fecha de interposición de la demanda, importe del débito originado por una subcontrata a favor de Marmolería Lemona, S. L. de aportación de materiales de marmolería y trabajos en la construcción de un parque de bomberos (...).

3) La Audiencia revocó la sentencia y absolvió a los administradores (...).

${ }^{44}$ STS de 4 de julio de 2007, Recurso 4503/2000 (ponente Marín CaStáN).

${ }^{45}$ STS de 20 de febrero de 2007, Recurso 3609/1999 (ponente XIOL Ríos) en recurso de apelación contra la sentencia dictada por la Audiencia Provincial de Bilbao de fecha de 17 de junio de 1999 del Juzgado de Primera Instancia número 2 de Bilbao. 
A) El art. 262.5 LSA, en la redacción aplicable por razones temporales al supuesto contemplado en este proceso, establece que, cuando concurran causas de disolución de la sociedad, «[r] esponderán solidariamente de las obligaciones sociales los socios administradores que incumplan la obligación de convocar en el plazo de dos meses la Junta General, para que adopte, en su caso, el acuerdo de disolución o que no soliciten la disolución judicial de la sociedad en el plazo de dos meses, a contar desde la fecha prevista para la celebración de la Junta, cuando esta no se haya constituido, o desde el día de la Junta, cuando el acuerdo hubiera sido contrario a la disolución».

Entre las causas de disolución a que este precepto se refiere figuran las «pérdidas que dejen reducido el patrimonio a una cantidad inferior a la mitad del capital social, a no ser que este se aumente o se reduzca en la medida suficiente» y la «reducción del capital social por debajo del mínimo legal» (causas 4 y 5 del art. 260.1 LSA).

En suma, la ley prevé, cuando concurren estas causas, un mecanismo preconcursal que consiste en que se obliga a la sociedad -antes de que sus pérdidas lo hagan imposible- a evitar el concurso, bien sea liquidándose, bien adoptando otro acuerdo alternativo tendente a reconstruir el patrimonio social y la efectividad de dicho mecanismo se garantiza imponiendo una responsabilidad solidaria a los administradores por las deudas sociales en caso de incumplimiento de la obligación de promoverlo.

B) La acción para reclamar la responsabilidad solidaria de los administradores por incumplimiento de la obligación de instar la disolución de la sociedad es, según la calificación jurisprudencial más reciente, una acción de responsabilidad extracontractual (SSTS de 4 de abril de 2006 y 24 de abril de 2006) dotada de singularidad en cuanto al requisito general de la relación de causalidad (STS 27 de octubre de 2006), pues la jurisprudencia ha venido declarando que esta responsabilidad no depende de la existencia de un nexo causal con el daño originado a los acreedores reclamantes, ni siquiera de la existencia del daño mismo, pues constituye una responsabilidad formal de carácter solidario respecto de las deudas sociales, que ha sido frecuentemente descrita como objetiva o cuasi objetiva, pues nace de la omisión del deber de promover la disolución en los supuestos legalmente previstos (SSTS de 3 de abril de 1998, 20 de abril de 1999, 22 de diciembre de 1999, de 20 de diciembre de 2000, 20 de julio de 2001, 25 de abril de 2002 y 14 de noviembre de 2002, entre otras).

A ello no obsta que en supuestos excepcionales la jurisprudencia haya considerado inexistente la responsabilidad de los administradores por no existir un interés digno de protección que justifique la responsabilidad (en expresión obiter dicta [ocasionalmente emitida] de las SSTS de 28 de abril de 2006 y 28 de noviembre de 2006), y haya reconocido, en consecuencia, límites al ejercicio de la acción fundados en principios generales, como ocurre en las SSTS de 20 de julio de 2001, 12 de febrero de 2003 y 16 de febrero de 2006. 
C) La responsabilidad que deriva del artículo 262.5 LSA exige no solamente que se produzca objetivamente una causa de disolución de la sociedad prevista en la ley, sino también que concurra la negligencia que contemplan los propios preceptos que establecen esta responsabilidad (SSTS de 20 de diciembre de 2000, 1 de marzo de 2001, 25 de abril de 2001, 20 de julio de 2001, 14 de noviembre de 2002, 12 de febrero de 2003, 16 de octubre de 2003, 26 de marzo de 2004, 16 de febrero de 2006, 6 de abril de 2006 y 28 de abril de 2006, recurso número 4187/2000, 26 de junio de 2006), de tal suerte que se registran supuestos en los que incluso el desconocimiento absoluto por el administrador de la marcha de la sociedad o la imposibilidad, entendida en términos de razonabilidad, de promover la disolución de la sociedad por parte del administrador se estiman como causas de exclusión de su responsabilidad.

D) En la precisión de la concurrencia de los supuestos que determinan la procedencia de la disolución de la sociedad y en la determinación de la conducta omisiva de los administradores este Tribunal debe atenerse a los hechos que el tribunal de instancia, en el ejercicio de sus facultades de valoración probatoria, solo revisable en casación en supuestos excepcionales, considere probados».

II $)^{46}$ QUINTO. Responsabilidad de los administradores derivada del artículo 262.5 LSA.

«En relación con el sistema de responsabilidad que dimana del artículo 262.5 LSA, y los presupuestos que han de concurrir para que se dé el supuesto de hecho previsto por la norma al que se liga el efecto de hacer al administrador solidariamente responsable de las deudas contraídas por la sociedad, esta Sala se ha pronunciado en el sentido de que la acción, y por ende, la responsabilidad que prevé el artículo 262.5 LSA, es distinta en sus presupuestos y en su regulación de la contemplada en los artículos 135 y 133 LSA. Mientras la acción individual requiere que concurran los requisitos de acción u omisión culposa, daño y prueba de la relación de causalidad (STS de 11 de

\footnotetext{
${ }^{46}$ STS 12 de marzo de 2010, Recurso 1535/2005 (ponente XIOL RiUs).

Otras muchas sentencias del Tribunal Supremo se centran en la aplicación del art. 262.5 L.S.A.; 4 de febrero de 2009, Recurso 794/2003 (ponente MARín CASTÁN); STS de 27 de noviembre de 2008, Recurso 1050/2003 (ponente Almagro Nosete). Donde, además, se examina el caso de cese de los administradores con anterioridad a producirse el hecho que constituye la causa de disolución; STS de 6 de noviembre de 2008, Recurso 1307/2003 (ponente CORBAL FERNÁNDEZ), donde se declara que es doctrina de la Sala «que la solicitud de suspensión de pagos no suple la omisión de promover la disolución de la sociedad» en caso de que concurra la causa legal de pérdidas económicas cualificadas y, por lo tanto, tal actividad no exonera de responsabilidad a los administradores; STS de 10 de julio de 2008, Recurso 710/2008 (ponente ALMAGRo NOSETE), aunque referida a la sociedad limitada y, por tanto, aplica el art. 105.5 L.S.R.L.; STS de 24 de marzo de 2008, Recurso 226/2008 (ponente Montes Penadés).
} 
julio de 2008, RC n. ${ }^{\circ} 3675 / 2001$ ), la acción del 262 LSA tiene un carácter abstracto o formal (STS de 26 de junio de 2006), cosa que se expresa en algunas sentencias atribuyéndole una naturaleza objetiva o cuasi objetiva (SSTS de 25 de abril de 2002, 14 de noviembre de 2002, 6 de abril de 2006 [Pleno], 28 de abril de 2006 y 26 de mayo de 2006, entre otras). De esto se sigue que su declaración no exige la concurrencia de más negligencia que la consistente en omitir el deber de promover la liquidación de la sociedad mediante convocatoria de la Junta o solicitando que se convoque judicialmente cuando sea el caso -y ahora también mediante solicitud de la declaración de concurso, cuando concurra su presupuesto objetivo-. No se exige, pues, una negligencia distinta de la prevista en la LSA (STSS de 20 y 23 de febrero de 2004 y de 28 de abril de 2006). Tampoco es menester que se demuestre la existencia de una relación de causalidad entre el daño y el comportamiento del administrador, sino que la imputación objetiva a este de la responsabilidad por las deudas de la sociedad se realiza ope legis [por ministerio de la ley] (SSTS de 28 de abril de 2006, 31 de enero de 2007, 10 de julio de 2008, RC n. ${ }^{\circ}$ 4059/2001, y 11 de julio de 2008, RC n. $\left.{ }^{\circ} 3675 / 2001\right) »$.

\section{III $)^{47} \ll$ FUNDAMENTOS DE DERECHO.}

PRIMERO.- El objeto del proceso versa sobre la exigencia de responsabilidad de unos administradores sociales por deuda de la entidad con base en no haber convocado Junta para disolver la sociedad de responsabilidad limitada cuando el patrimonio contable social se había reducido a menos de la mitad del capital social, todo ello de conformidad con los arts. 104.1,e) y 105.5 de la Ley de Sociedades de Responsabilidad Limitada 2/1995, de 23 de marzo. La Sentencia dictada por el Juzgado de 1. ${ }^{a}$ Instancia número 3 de Móstoles el 14 de diciembre de 2004, en los autos de juicio ordinario número 420 de 2004, estimó la demanda formulada por el Banco de Bilbao Vizcaya Argentaria S.A. contra Dn. Baltasar y Dn. Fulgencio, y, después de declarar que los demandados han incumplido como administradores de la entidad mercantil Embutidos Simón, S.L. las obligaciones inherentes a su cargo, les condena a que, solidariamente, abonen a la actora la cantidad de trescientas ochenta y ocho mil, seiscientos cincuenta y siete euros con setenta y un céntimos $-388.657,71$ euros-, y al pago de las costas procesales causadas.

La Sentencia dictada por la Sección 18. ${ }^{\mathrm{a}}$ de la Audiencia Provincial de Madrid el 10 de octubre de 2005, en el Rollo número 273 de 2005, estima el recurso de apelación de los demandados, revoca la resolución de primera instancia, y desestima la demanda, absolviendo a los codemandados. Además, impone las costas de la primera instancia a la parte actora y no hace especial pronunciamiento respecto de las de la alzada.

${ }^{47}$ STS 12 de febrero de 2010, Recurso 279/2006 (ponente CORBAL FERNÁNDEZ). 
Por el Banco Bilbao Vizcaya Argentaria, S.A. se interpuso recurso de casación articulado en un único motivo en el que denuncia infracción de los arts. 104,e) y $105 \mathrm{LSRL}$, que fue admitido por Auto de esta Sala de 8 de julio de 2008.

El argumento de la resolución recurrida desconoce la doctrina jurisprudencial reiterada de que no se requiere la concurrencia del reproche culpabilístico (SS., entre otras, 28 de abril y 26 de mayo de 2006, 20 de noviembre de 2008, 1 de junio de 2009), lo que debe entenderse sin perjuicio de que determinadas conductas en determinadas circunstancias, como se expuso, pueden dar lugar a una exoneración de responsabilidad, paliando los efectos de lo que se ha llegado a calificar como modalidad de responsabilidad objetiva o "cuasi objetiva". Se menciona también por la resolución recurrida como causa para desestimar la pretensión actora que en la Junta de la Sociedad celebrada en marzo de 2001 se acordó solicitar la declaración de quiebra voluntaria, la que fue admitida a trámite por Auto de 26 de marzo, y se añade que el día 27 de marzo el Banco actor cerró las cuentas [cancelación anticipada de las pólizas] si bien no se certificó el saldo deudor hasta el día 7 de mayo de 2001.

La presentación de la solicitud de quiebra voluntaria, al tiempo de los hechos, no era por sí sola suficiente para excluir la responsabilidad de los administradores (S. 29 de mayo de 2009), y aun cuando pudiera caber hacer ciertas matizaciones, estas resultan estériles ante dos hechos relevantes: la gravedad de la situación financiera y la tardanza de más de año y medio en solicitar la declaración de quiebra, sin que excuse la alegación de haberse intentado medidas de reflote, pues las indicadas al respecto no revestían visos de éxito para lograr el reequilibrio patrimonial. Y por otro lado nada obsta a que por el Banco actor se cancelaran las pólizas al producirse la declaración de quiebra, pues los créditos existían y nada consta que impidiera el legítimo ejercicio de la facultad de vencimiento anticipado».

IV $)^{48}$ Esta sentencia que sigue tiene el interés de graduar la responsabilidad del administrador frente a terceros en función de la buena fe o conocimiento por esos terceros de la situación de dificultad económica que atravesaba la compañía con los que contrataron.

«FUNDAMENTOS DE DERECHO.

PRIMERO.- 1.- El conflicto.-

1.1.- STIL GARDEN S.p.A. demanda a D. David en reclamación de la cantidad de 235.302,82 €, a consecuencia del impago de determinada deuda por la sociedad STIL GARDEN PLASTIC, S.A., de la que era Administrador Único. Ejercita la acción individual de responsabilidad de los artículos 133 y 135, y la acción de responsabilidad de los artículos 260 y 262.5 de

${ }^{48}$ STS de 114 de mayo de 2009, Recurso 1926/2004 (ponente MonTEs PenAdÉs). 
la Ley de Sociedades Anónimas. 1.2.- El demandado, que reconoce la existencia de la deuda y el estado de insolvencia de la sociedad que administraba, así como el hecho de no haber convocado la Junta a que se refiere el artículo 262.2 LSA, opone que la actora, socia de la compañía demandada y ex administradora, conocía la situación de insolvencia y, ello no obstante, aceptó el suministro de materiales. Este hecho es aceptado por la actora. El demandado opone también la actitud pasiva de la actora, que, siendo accionista, no instó la convocatoria de la Junta General ni la remoción del Administrador.

1.3.- El demandado fue nombrado administrador en 1966 cuando la sociedad ya estaba en estado de insolvencia, que se había producido durante la etapa en que la sociedad había sido regida por un Consejo de Administración del que formaba parte la entidad ahora demandante. En 2 de febrero de 1996 se firma un documento (folio 75 de los autos) en el que se conviene (entre los ahora litigantes y una sociedad denominada PINTVAL SERVICIOS S.L. -dominada por el demandado-) que se pagarían las deudas de STIL GARDEN PLASTIC, S.A. con STIL GARDEN, S.p.A. en dos vencimientos, el 30 de mayo y el 30 de junio siguientes, y se establece: “... después del 1 de julio de 1996 la sociedad STIL GARDEN PLASTIC, S.A. en cualquier caso tendrá que ser puesta en liquidación; en caso de que por cualquier causa no pudiera ser liquidada los socios se comprometen ya desde ahora a variar su denominación social...”.

El demandado reconoce en su declaración durante el juicio oral la existencia del pacto, la situación de infracapitalización de la sociedad, y el hecho de que no la puso en liquidación.

[El Juzgado de Primera Instancia estima la demanda, y la Sala de Apelación confirma su sentencia].

SEGUNDO.- El Recurso de casación presenta tres motivos, que se resumen a continuación.

En el primero se denuncia la infracción de los artículos 262.5 y 260 LSA en relación con los artículos 7 y 1258 CC y 57 CCom. El motivo se fundamenta en la jurisprudencia de esta Sala, especialmente contenida en las SSTS 20 de julio de 2001, 12 de febrero de 2003 y 16 de octubre de 2003, en el sentido de que en la aplicación de la regla del artículo 262.5 LSA debe ponderarse el principio de buena fe, de modo que cuando el tercero que contrata con la sociedad conocía la situación patrimonial de la sociedad no puede dirigirse posteriormente contra los administradores, pues el conocimiento de la situación por los socios o el conocimiento de la infracapitalización por el acreedor en el momento de contratar no les autoriza para dirigirse luego contra los administradores. El artículo 262.5 LSA exigiría, además de la situación de infracapitalización y la ausencia de convocatoria de Junta, que el acreedor que reclama no fuera consciente al tiempo de convenir su crédito, a la postre incumplido, de la situación de crisis patrimonial que atravesaba la entidad y el riesgo que por ello asumía. Lo que en el caso está proba- 
do, y no puede ser obviado por la existencia del Convenio de 2 de febrero de 1996 puesto que, incluso si se aceptara el carácter de pacto liquidatorio que le da la sentencia recurrida, revela que la deuda que en dicho pacto se liquida no fue asumida de forma ingenua y sin conocimiento por la actora, sino siendo conocedora de la situación de déficit patrimonial. La actora era accionista y había sido administradora desde la constitución de STIL GARDEN PLASTIC, S.A. y consta en Autos su participación y aceptación en las cuentas anuales que reflejaban desde el inicio de la actividad la deficiente situación patrimonial y financiera de dicha sociedad, por lo que la deuda que liquida el pacto de 2 de febrero de 1996 fue asumida con pleno conocimiento de la situación de infracapitalización. Además de que la deuda origen de esta reclamación no era anterior al convenio de 2 de febrero de 1996, sino posterior a esta y fruto del suministro de materiales que en el mismo se pacta. El motivo segundo denuncia la infracción de los artículos 262.5 y 260 LSA en relación con los artículos 133 y 135 de la misma Ley.

Dice el recurrente que la Sala de instancia sale del ámbito del 262.5 LSA "para invadir el presupuesto de hecho de las acciones previstas en los artículos 133 y 135 de la propia LSA". Para poder estimar una pretensión basada en los artículos 133 y 135 LSA es indispensable probar la existencia de la conducta negligente o el acto contrario a ley o los estatutos, el daño y la relación causal entre el acto ilícito y el daño acreditado, como entre otras puede leerse en la STS 28 de junio de 2000. Se ataca sobre todo la conexión causal entre un acto del administrador y la situación deficitaria de la sociedad que le impide pagar la deuda.

No es suficiente invocar la falta de presentación de las cuentas en el RM (STS 27 de mayo de 2004). Invoca el recurrente las SSTS de 21 de septiembre de 1999, 27 de mayo de 2004, que cita muchas otras, y las de 16 de febrero de 2000, y 3 de julio de 1998.

Finalmente, en el motivo tercero se denuncia la infracción de los artículos 126 LSA y 125 RRM. La actora ha invocado -dice el recurso- como causa de infracapitalización la condena al pago de 235.302,82 € impuesta por la Sentencia dictada por la Audiencia Provincial de Valencia en 19 de junio de 2002 , fecha posterior a la caducidad del mandato como administrador y a su prórroga legal, pues la condena en primera instancia, anterior, no era firme.

TERCERO.- La cuestión central gira en torno de una elección entre sancionar a un Administrador contumaz que, obligado por la Ley y por un pacto especial convenido con sus socios, no verifica la convocatoria de la Junta prevista en el artículo 262.2 LSA, con lo que se le impone la responsabilidad consistente en asumir la deuda de la sociedad que administraba, o bien imponer a la sociedad actora, que conocía perfectamente la situación de insolvencia de la sociedad con la que contrata un nuevo suministro, las consecuencias de una operación mercantil asumida a riesgo y ventura, cuya frustración le conduce, después de haber obtenido la condena de la sociedad deudora en otro procedimiento, a reclamar del Administrador, lo que parece contrario a 
la buena fe, que se ha de tener en cuenta según la jurisprudencia de esta Sala, que está bien citada en el recurso.

El eje de la solución se encuentra en el valor que haya que dar al pacto, establecido en 2 de febrero de 1996, por el que las partes se obligan a poner en liquidación la sociedad deudora. A juicio de la Sala de instancia, la existencia de este pacto impide que pueda ser subsumida la situación en un supuesto de carencia de buena fe en el reclamante, según la jurisprudencia antes aludida.

Un dato que hay que tener en cuenta es que la sociedad ahora demandante obtuvo la condena de la sociedad administrada por el demandado en un procedimiento anterior, en el que no fue parte el administrador.

CUARTO.- La sociedad reclamante era perfectamente conocedora, pues, de la infracapitalización de la sociedad con la que contrataba (participada por la actora, que además había sido administradora). El pacto de 2 de febrero de 1996 ciertamente obligaba a poner en liquidación la sociedad, después de verificar el pago del crédito por el suministro ahora convenido, pero no evita que se trate de una operación que hay que poner a riesgo de la sociedad ahora reclamante, consciente de la situación patrimonial de la entidad deudora. Esta Sala ha distinguido entre las acciones de responsabilidad individual (artículos 133 y 135 LSA) y la de responsabilidad especial que impone a los administradores el artículo 262.5 de la propia LSA por no promover la disolución (o en los términos de la actual redacción del precepto, el concurso) de la sociedad, y ha admitido que, en régimen de concurso ideal, la situación de insolvencia puede dar paso a la responsabilidad individual, cuando la insolvencia de la sociedad provocada por la negligencia de los administradores causa una lesión directa a los acreedores (SSTS 11 de octubre de 1991, 10 de diciembre de 1996, 11 de noviembre de 1997, 17 de diciembre de 2003, 20 de febrero de 2004, etc.), pero también ha dicho (STS 16 de octubre de 2003, entre otras) que la responsabilidad ex artículo 262.5 LSA tiene su "ratio" en que la conducta omisiva de los administradores ha inducido a error a un determinado tercero contratante, haciéndole creer que la sociedad se encuentra en una situación normal desde los puntos de vista económico y financiero. Téngase en cuenta que el pacto preveía la liquidación a partir del $1 .^{\circ}$ de julio de 1996, y la sociedad ahora reclamante demandó primero el pago frente a la sociedad administrada por el demandado, ya en 2001, sin otra actividad por su parte.

QUINTO.- Aun cuando un amplio número de sentencias de esta Sala han perfilado la responsabilidad ex artículo 262.5 LSA como un supuesto de responsabilidad objetiva o "cuasiobjetiva" (SSTS 20 de diciembre de 2000, 20 de julio de 2001, 25 de abril y 14 de noviembre de 2002), otro grupo numeroso de sentencias han precisado que requiere la aplicación de las técnicas y de las reglas de responsabilidad civil, evaluando los problemas de imputación objetiva, entre los cuales se encuentra el conocimiento por los reclamantes de la situación de la sociedad en el momento de generación del 
crédito (SSTS 28 de abril de 2006, RC 3287/1999; y 28 de abril de 2006, RC 4187/2000, 14 de marzo de 2007, etc.). La STS de 20 de julio de 2001, que sigue la línea de otras decisiones, como las SSTS de 16 de febrero de 2000, RC 1449/1995, y 3 de julio de 1998, señalaba que el consentimiento de la situación por los socios o el conocimiento de la infracapitalización por el acreedor al momento de contratar con la sociedad no les autoriza para dirigirse luego contra los administradores. La STS de 12 de febrero de 2003 decía que hay que tener en cuenta el artículo 7.1 del Código civil, que obliga al ejercicio de los derechos conforme a las exigencias de la buena fe. Y la de 16 de octubre de 2003, antes ya citada, reitera esta misma idea, que también es apuntada en la STS de 27 de mayo de 2004, en la que se dice que el perjudicado no puede fundamentar la responsabilidad del Administrador en aquellas circunstancias que conocía o debía conocer al tiempo de contratar, y entre ellas las dificultades económicas existentes en el momento del pacto para saldar la deuda.

SEXTO.- Estas consideraciones inclinan a la Sala a estimar el recurso, en concreto los motivos primero y segundo, por lo que es irrelevante el examen del motivo tercero. La actora no actuó en buena fe, y, como señala el recurrente, el comportamiento en buena fe es presupuesto de la tutela del derecho que se ejercita, de acuerdo con lo dispuesto en los artículos 7.1 y $1258 \mathrm{del} \mathrm{Códi-}$ go civil y 57 del CCom., entendiendo la buena fe como un comportamiento honrado, justo, leal y lógico (SSTS 11 de diciembre de 1989, 20 de octubre de 1991, 22 de febrero y 1 de marzo de 2001, 14 de mayo de 2002, 20 de junio y 4 de julio de 2006, 3 de enero de 2007, entre muchas otras). La actora, perfectamente consciente de la situación de infracapitalización en que se encontraba la sociedad deudora, concedió nuevos suministros, de los que derivó el crédito que ahora reclama, realizando una operación que hay que poner a su riesgo y ventura. Por otra parte, el incumplimiento del pacto establecido (Fundamento Jurídico Primero, sub 1.3), única base para establecer la responsabilidad individual por aplicación de los artículos 133 y 135 LSA, requiere que se demuestre la relación de causalidad entre la omisión del Administrador demandado y el daño, que en el caso consiste en la imposibilidad de cobro de la deuda, pero es claro que tal imposibilidad no deriva del incumplimiento del pacto de poner a la sociedad en liquidación, sino de la insolvencia de la sociedad, que no hubiera sido remediada por el cumplimiento del pacto».

V) ${ }^{49}$ Sobre posibles causas de exoneración -solo en caso extraordinarios-de la responsabilidad objetiva ex art. 262.5 L.S.A.

«SÉPTIMO. Requisitos de la responsabilidad de los administradores.

Las razones en las que se funda la desestimación del anterior motivo son las siguientes:

${ }^{49}$ STS de 2 de diciembre de 2008, Recurso 3713/2001 (ponente XIOL Ríos). 
A) En la medida en que se impute una incongruencia a la sentencia recurrida, esta alegación debe ser desechada, por cuanto resulta evidente que en la demanda se invocó no solamente los preceptos relativos al ejercicio de la acción individual de responsabilidad contemplada en la LSA, sino también la responsabilidad objetiva o formal por incumplimiento de la obligación de disolución por parte de los administradores al concurrir causas legales para ello, al amparo del artículo 262.5 LSA.

B) Por otra parte, el hecho de que en la sentencia del Juzgado se haga un especial hincapié en la negligencia de los administradores y, en general, en los elementos propios del ejercicio de la acción individual, no es obstáculo para que, de acuerdo con la pretensión formulada en la demanda, la Audiencia Provincial pueda basar su pronunciamiento en la acción derivada de la responsabilidad por incumplimiento de la obligación que corresponde a los administradores de promover la disolución de la sociedad cuando concurren los presupuestos legales establecidos para ello.

C) El plazo de prescripción de la responsabilidad de los administradores es, según la más reciente jurisprudencia, el de 4 años previsto en el artículo 949 CCom, como se ha recordado con anterioridad.

D) La jurisprudencia en casos extraordinarios ha admitido que la imposibilidad por parte de los administradores de conocer la situación de la sociedad o de promover la disolución puede ser una causa de exoneración de su responsabilidad por falta de los presupuestos necesarios con carácter general para su existencia, ya que nadie puede ser obligado a lo imposible (SSTS de 1 de marzo de 2001, 20 de junio de 2001, 12 de febrero de 2003, 16 de octubre de 2003, 26 de marzo de 2004, 16 de febrero de 2006, y 28 de abril de 2006, recurso número 4187/2000); pero resulta evidente que el carácter formal u objetivo de esta responsabilidad no permite excluirla por el hecho de que los administradores hayan tratado de evitar o minorar las consecuencias del daño causado, ya que el precepto legal persigue, en beneficio de todos los acreedores de la sociedad y con el fin de garantizar la liquidación ordenada de la misma, que los acreedores promuevan su disolución cuando concurran las condiciones que la exigen (SSTS de 3 de abril de 1998, 20 de abril de 1999, 22 de diciembre de 1999, de 20 de diciembre de 2000, 20 de julio de 2001, 25 de abril de 2002 y 14 de noviembre de 2002, 26 de junio de 2006, rec. 4434/1999)».

VI) ${ }^{50}$ Sobre circunstancias que no exoneran de la responsabilidad del art. 262.5 L.S.A.

«El recurso de casación se interpone únicamente por uno de los dos administradores codemandados y se articula en cinco motivos formulados al amparo del ordinal $4 .^{\circ}$ del art. 1692 LEC de 1881. SEGUNDO.- El motivo

${ }^{50}$ STS de 24 de junio de 2008, Recurso 3077/2001 (ponente MARÍn CASTÁN). 
primero denuncia "una interpretación literal y rigorista del artículo 262.5 LSA contraria a la naturaleza del cargo de administrador de sociedades mercantiles". Según su desarrollo argumental, el recurrente llevó la gestión de la compañía de forma ordenada y diligente, procurando en todo momento la publicidad de su situación real en el Registro Mercantil y acogiéndose en su momento a la suspensión de pagos para alcanzar un convenio con los acreedores sociales. En su opinión, los arts. 260 y 262 LSA tienen que ponerse en relación con los arts. 127 y 133 de la misma ley porque lo decisivo es que los administradores desempeñen su cargo diligentemente, y si lo han hecho no deberán responder por las deudas sociales. En suma, para la parte recurrente, que no discute que la sociedad estuviera incursa en causa de disolución ni que sean aplicables al caso las normas sobre responsabilidad de los administradores del texto refundido de la LSA de 1989 por remisión de la LSRL de 1953 tras su reforma por la Ley 19/89, no cabe responsabilidad de los administradores si estos han actuado con diligencia y buena fe dando publicidad a las cuentas sociales, de suerte que si no se promovió la disolución de la compañía fue por la subsistencia de su capacidad de crédito dada la fluctuación del equilibrio patrimonial en un mercado como el inmobiliario en el que operaba la sociedad. Finaliza el alegato del motivo recordando que la sociedad demandada solicitó los beneficios de la Ley de Suspensión de Pagos de 1922, en cuyo expediente los acreedores habrían podido exigir responsabilidad a los administradores, y no solo no lo hicieron sino que incluso convinieron con la sociedad deudora su ordenada liquidación.

Semejante planteamiento no puede ser aceptado y por tanto el motivo ha de ser desestimado, porque no es en absoluto cierto que la responsabilidad solidaria de los administradores sociales establecida en el art. 262.5 LSA (redacción anterior a su reforma por la Ley Concursal de 2003) exija una negligencia distinta de la contemplada en el propio precepto y consistente en el incumplimiento de la obligación de convocar en el plazo de dos meses la Junta General para la adopción, en su caso, del acuerdo de disolución, según viene declarando la jurisprudencia de esta Sala (SSTS 21-2-07, 23-6-06, 1612-04, 1-3-04, 23-12-03, 20-10-03, 2-6-02, 20-7-01 y 31-5-01 entre otras muchas). Ello significa que si los administradores, además, incumplen otros deberes, como podrían ser los relativos a las cuentas anuales, cabrán otras acciones añadidas contra ellos, pero no que tal incumplimiento sea requisito necesario de la responsabilidad declarada por la sentencia recurrida. Finalmente, tampoco quedaban los administradores exonerados de esta responsabilidad por el mero hecho de promover la declaración de la sociedad en estado de suspensión de pagos al amparo de la Ley especial de 1922, ya que el expediente correspondiente no estaría en principio orientado a disolver la compañía sino a la continuación de su actividad (SSTS 19-9-07, 21-2-07, 64-06 y 16-12-04).

TERCERO.- El motivo segundo, fundado en interpretación incorrecta del art. 262.5 LSA en relación con la fe pública registral, así como del art. 6 
$C C$, tiene un planteamiento muy similar al anterior porque, afirmando el recurrente que los administradores "serían responsables de las deudas, no tanto por la existencia de una causa de disolución, sino, o necesariamente unido, por la ocultación al mercando de dicha causa", vuelve a insistir en su exoneración por el hecho de que las cuentas publicadas por el Registro Mercantil reflejaban el déficit patrimonial de la sociedad codemandada $\mathrm{y}$, por tanto, tal déficit pudiera ser conocido por la acreedora demandante antes de contratar, de suerte que esta debería asumir los riesgos derivados de haber contratado en lugar de desplazarlos sobre los administradores. Se alega también que al depositar la sociedad deudora las cuentas que revelan su causa de disolución, "subsana este vicio para los que contraten con ella con posterioridad pues son perfectos conocedores de esta situación". Se añade que "castigar" en este caso a los administradores supone imponerles una penalización que la ley no contempla, "cual es la de convertir a dichos administradores en avalistas, por imperativo legal, de las deudas sociales", y también que la sociedad demandante, al decidir contratar con la compañía demandada, "renunció tácitamente" a reclamar contra sus administradores, por lo que vendría al caso la cita del art. 6.2 CC así como la aplicación de la doctrina de los actos propios.

Pues bien, el motivo ha de ser desestimado partiendo de lo razonado para desestimar el motivo anterior. Es cierto que en casos excepcionales algunas sentencias de esta Sala han exonerado de responsabilidad a los administradores pese a estar incursa la compañía en causa de disolución, pero no por la oportunidad de quienes hubieran contratado con esta de conocer el desequilibrio patrimonial consultando el Registro Mercantil sino en virtud de hechos plenamente probados y relativos bien a pactos especiales entre acreedor y sociedad deudora para superar la situación, a modo de acuerdos bilaterales de colaboración, bien a la imposibilidad material de los nuevos administradores de hacerse cargo de la situación, bien a la ausencia total de daño (SSTS 26-6-06, 16-2-06, 26-4-05 y 16-10-03), habiéndose declarado por una de esas sentencias, la de 16-10-03, que "sería una rémora importantísima para la rapidez de las transacciones mercantiles que hubiera que acudir al Registro Mercantil para enterarse de la solvencia de la persona con quien se quiere concertar una operación, salvo que se trate de profesionales a los que el uso de los negocios impone investigar dicha solvencia".

Descartado, pues, que la publicidad registral del desequilibrio patrimonial constituya una causa de exención de la responsabilidad del art. 262.5 $L S A$, a modo de excepción no contemplada en la norma, también deben rechazarse los otros argumentos del motivo: el atinente a la "penalización" que dicho precepto impondría a los administradores como garantes de las deudas sociales, porque precisamente ese es el sentido de la norma al establecer la responsabilidad solidaria, según declaró esta Sala en su sentencia de 21 de febrero de 2007 (recurso n. $^{\circ}$ 923/00) refiriéndose a la asunción solidaria de obligaciones o en la de 20 de febrero de 2007 (recurso n. ${ }^{\circ} 289 / 00$ ) 
refiriéndose al administrador como "deudor acumulado"; y el relativo a la alegada renuncia de la sociedad demandante o a sus actos propios, porque como declaró la sentencia de esta Sala de 16 de diciembre de 2004 (recurso n. ${ }^{\circ} 3375 / 98$ ), los acreedores no tienen la carga de promover la disolución de la sociedad deudora como requisito previo a la acción de responsabilidad de sus administradores, aunque sí gozan de la facultad subsidiaria de hacerlo.

CUARTO.- El tercer motivo del recurso, fundado en la interpretación rigorista de los arts. 260.1-4. ${ }^{\circ}$ y $262.5 \mathrm{LSA}$ por el tribunal sentenciador, contraria según el recurrente a la Ley de Suspensión de Pagos de 1922 y a la sentencia de esta Sala de 13 de abril de 2000, también ha de ser desestimado por las razones ya señaladas en el fundamento jurídico segundo sobre la ineficacia de la solicitud del estado de suspensión de pagos de la sociedad deudora para exonerar de responsabilidad a los administradores, máxime si, como se admite en el propio alegato del motivo, la causa de disolución existía ya en 1989, pese a lo cual el expediente de suspensión de pagos no se promovió hasta julio de 1994 y, como declara probado la sentencia recurrida, esta iniciativa fue posterior también a la presentación de la demanda exigiendo responsabilidad a los administradores. Finalmente, la cita de la sentencia de esta Sala de 13 de abril de 2000 (recurso n. $^{\circ}$ 2143/95) tampoco sirve a la finalidad perseguida por el recurrente: primero, porque la doctrina reiterada de esta Sala, y por tanto su jurisprudencia, es la inidoneidad de la suspensión de pagos para exonerar de responsabilidad a los administradores, según sentencias ya citadas en dicho fundamento jurídico; y segundo, porque el recurrente ofrece su propia interpretación de la sentencia que cita para darle el sentido que conviene a su interés, ya que en ningún caso dicha sentencia declara que promover la suspensión de pagos exima de responsabilidad a los administradores».

VII $)^{51}$ Valoración de la conducta de los administradores en atención a las excepcionales circunstancias concurrentes.

«SEGUNDO.- El único motivo del actual recurso se denuncia la infracción del artículo 262.5 en relación con el 260.4 de la Ley de Sociedades Anónimas, y se dice así mismo vulnerada la doctrina que los interpreta, contenida en las sentencias que se citan, en la medida en que la Audiencia, soslayando, a juicio de la parte recurrente, el carácter objetivo que presenta la responsabilidad a que se alude en el primero de los referidos preceptos, se decanta por exonerar de toda responsabilidad a los miembros del Consejo de Administración demandados valorando positivamente el esfuerzo desplegado por estos y las medidas así mismo adoptadas tendentes a paliar la situación de crisis, y al reflotamiento y mejora de la sociedad, lo que supone des-

${ }^{51}$ STS de 20 de noviembre de 2008, Recurso 3584/2001 (ponente SIERRA GIL DE LA Cuesta). 
conocer el mandato legal, en que la responsabilidad de los administradores "se anuda, única y exclusivamente con el incumplimiento de su obligación de convocar la junta general...".

El motivo debe ser desestimado.

Constituye ciertamente doctrina pacífica y constante, de la que son claro ejemplo las Sentencias de 31 de enero y 8 de marzo de 2007, mencionadas por la más reciente de 11 de Julio de 2008, "que la acción y por ende, la responsabilidad que prevé el artículo 262.5 LSA, es distinta en sus presupuestos y en su regulación legal a la contemplada en los artículos 135 y 133 del citado texto legal", presentando aquella un carácter abstracto o formal, o, más propiamente, "una naturaleza objetiva o cuasi objetiva" (Sentencias de 25 de abril de 2002, 14 de noviembre de 2002, 6 y 28 de abril de 2006 -esta última de Pleno-, y 26 de mayo de 2006, entre otras), que determina, por regla general, que no sea preciso para apreciar la responsabilidad del administrador demandado ni la concurrencia de un reproche culpabilístico que hubiera que añadir a la constatación de que no ha habido promoción de la liquidación mediante convocatoria de la Junta o solicitud judicial de disolución, en su caso -y ahora también la solicitud de la declaración de concurso, cuando concurra su presupuesto objetivo-, ni una estricta relación de causalidad entre el daño y el comportamiento concreto de administrador, por bastar el enlace causal preestablecido en la propia norma -Sentencia de 28 de abril de 2006-. Ahora bien, sin perjuicio de lo anterior, ha sentado esta Sala a partir de la Sentencia de Pleno de 28 de abril de 2006, que las especiales o extraordinarias circunstancias que puedan concurrir en un determinado caso en torno a la concreta conducta desplegada por los administradores, y que consten acreditadas, pueden llegar a justificar, aun cuando se acciona con base en dicho precepto legal, que se exonere de responsabilidad a los gestores, siendo ello debido a que la responsabilidad ex lege del artículo 262.5 LSA ha de ser entendida en clave de responsabilidad civil. En palabras de la citada Sentencia de 28 de abril de 2006, aun sin perder de vista su carácter de sanción, «se ha de tomar como punto de partida la existencia de un daño (un crédito contra la sociedad, cuya frustración, desde la perspectiva del artículo 135 LSA, sería un daño indirecto, ya que la insolvencia de la sociedad deudora no puede tomarse como un supuesto de lesión directa causada por los administradores), que se relaciona causalmente de modo muy laxo con el comportamiento omisivo de los administradores (carencia de convocatoria en plazo, omisión del deber de solicitar la disolución judicial o el concurso), pero que, a partir de ese dato (daño y relación de causalidad preestablecida) requeriría la aplicación de las reglas y de las técnicas de responsabilidad civil, evaluando los problemas de imputación objetiva (conocimiento por los reclamantes de la situación de la sociedad en el momento de generación del crédito, solvencia de la sociedad, existencia de créditos compensables de la sociedad frente a los acreedores que reclaman) y de imputación subjetiva, esto es, la posibilidad de exoneración de los administradores que, aun cuan- 
do hayan de pechar con la carga de la prueba (artículo 133.3 LSA) demuestren una acción significativa para evitar el daño (lo que se ha de valorar en cada caso) o que se encuentren ante la imposibilidad de evitarlo (han cesado antes de que se produzca el hecho causante de la disolución, se han encontrado ante una situación ya irreversible). Valoración de la conducta de los administradores que se ha de producir forzosamente si se estableciera que estamos ante una sanción o pena civil (lo que requiere una matización, como se verá) pues lo exigen los principios del sistema, y que aparece ya en decisiones anteriores, bajo diversos expedientes (Sentencias de 1 de marzo y 20 de junio de 2001, de 12 de febrero y 16 de octubre de 2003, de 26 de marzo de 2004, de 16 de febrero de 2006, entre otras)».

En línea con este criterio jurisprudencial se muestra la Sentencia de 22 de noviembre de 2006, en la cual se afirma que esta caracterización de la responsabilidad (como objetiva o cuasi objetiva) «no empece a que los principios del sistema que rigen en nuestro ordenamiento jurídico, y en especial la necesaria conexión entre las responsabilidades de la Ley de Sociedades Anónimas y las reglas generales de los artículos 1902 y siguientes del Código Civil -y la jurisprudencia que los desarrolla-, determinen la necesidad de templar su apreciación y consecuencias, en razón de la valoración de la conducta de los responsables atendiendo a las circunstancias de carácter objetivo y subjetivo concurrentes, esta Sala ha considerado relevante para mitigar el rigor del régimen de los artículos 262-5. ${ }^{\circ}$ de la Ley de Sociedades Anónimas y $105-5^{\circ}$ de la Ley de Sociedades de Responsabilidad Limitada y para exonerar de responsabilidad al administrador el conocimiento del acreedor reclamante de la situación económica de la sociedad en el momento de la generación del crédito -Sentencias de 16 de febrero y de 28 de abril de 2006, del Pleno-, y, en términos más amplios, su actuación contraviniendo las exigencias de la buena fe-Sentencia de 12 de febrero de 2003-, la solvencia de la sociedad o la existencia de créditos compensables de la sociedad frente a los acreedores que reclaman-Sentencia de 28 de abril de 2006, del Pleno-; y se ha atendido también al hecho de que los administradores, aun cuando deban soportar la carga de la prueba, demuestren una acción significativa para evitar el daño, lo que se ha de valorar en cada caso -en este sentido, vid. Sentencia de 28 de abril de 2006, de Pleno-, o que se encuentren ante la imposibilidad de evitarlo, por haber cesado antes de que se produzca el hecho causante de la disolución -Sentencias de 28 de abril de 2006, de Pleno, y de 26 de mayo de 2006, entre las más recientes-, o, en términos generales, por haberse encontrado ante una situación ya irreversible -Sentencia de 28 de abril de 2006-. Todos estos casos, expuestos a título meramente enunciativo, contemplan -en palabras de la Sentencia de 26 de junio de 2006- situaciones que resultan incompatibles con el concepto de responsabilidad, entendido con arreglo a los requisitos de la responsabilidad extracontractual en general». Y, en fin, en parecidos términos se expresa la más reciente Sentencia de 5 de diciembre de 2007. 
La proyección de estas notas caracterizadoras de la responsabilidad y de los criterios jurisprudenciales expuestos al supuesto de autos, justifica la absolución de los administradores demandados en cuanto los hechos tenidos por probados, incólumes en casación, acreditan un esfuerzo significativo de los administradores a la hora de evitar el daño que para la sociedad demandante supuso la insatisfacción del crédito que ostentaba contra la sociedad demandada $(\ldots) \gg$.

VIII ${ }^{52}$ Más sobre atemperación de la responsabilidad de los administradores ex art. 262.5 L.S.A.

«La responsabilidad de que se trata -continúa diciendo la Sentencia de 28 de abril de 2006- no se basa en la relación de causalidad entre un determinado acto lesivo -como ocurre en la de los artículos 133 y 135 LSA- y el daño, que generalmente consiste en el impago de un crédito, puesto que, al menos en la causa de disolución del artículo 260.1.4. ${ }^{\circ}$ LSA, es la insolvencia de la sociedad, la insuficiencia de su patrimonio, el factor determinante de la frustración del crédito que ahora se reclama. No hay aquí la lesión directa que exige el artículo $135 \mathrm{LSA}$, pero puede haber un riesgo o peligro de que, en defecto de una liquidación ordenada, los acreedores de la sociedad sufran el agravamiento de su posición o los efectos de un comportamiento desordenado o arbitrario de su deudor, la sociedad, cuyo patrimonio es en principio la única garantía, que por efecto de este precepto se ve reforzada con la de los administradores que no hayan promovido la liquidación o el concurso a su debido tiempo».

Ahora bien, tal y como se precisa en las sentencias de 28 de abril de 2006 (del Pleno) y de 5 de octubre de 2006, esta caracterización de la responsabilidad no obsta a que los principios del sistema de responsabilidad general, y en especial la necesaria conexión entre las responsabilidades de la Ley de Sociedades Anónimas y las reglas generales de los artículos 1902 y siguientes del Código Civil -y la jurisprudencia que los desarrolla-, determinen la necesidad de atemperar su apreciación y consecuencias, en razón de la valoración de la conducta de los responsables atendiendo a las circunstancias de carácter objetivo y subjetivo concurrentes; valoración a la que también es necesario llegar -como indica la sentencia de 28 de abril de 2006- si se parte de una concepción de la responsabilidad de que se trata como una suerte de sanción. En esta sentencia se explica esta modulación, partiendo de que la responsabilidad de los artículos 262.5 del Texto Refundido de la Ley de Sociedades Anónimas y 105.5 de la Ley de Sociedades de Responsabilidad Limitada, constituye un supuesto de responsabilidad extracontractual -no obstante decisiones orientadas en otro sentido-que requiere la existencia de

\footnotetext{
${ }^{52}$ STS de 5 de diciembre de 2007, Recurso 1325/2005 (ponente SIERRA GIL DE LA CuES$\mathrm{TA})$.
} 
un daño, por lo general, el impago del crédito que se reclama, el cual se presenta como indirecto desde la perspectiva del artículo 135 de la Ley de Sociedades Anónimas -toda vez que la insolvencia de la sociedad deudora no puede tomarse como un supuesto de lesión directa causada por los administradores-, y enlazado causalmente de forma muy laxa con el comportamiento omisivo de los administradores como son la carencia de convocatoria en plazo, o la omisión del deber de solicitar la disolución judicial o el concurso.

\section{RESPONSABILIDAD DEL ADMINISTRADOR POR NO ADAPTAR LOS ESTATUTOS A LA LEY DE SocIEDADES ANÓNIMAS ANTES DEL 30 DE JUNIO DE 1992}

\section{I) ${ }^{53}$ «FUNDAMENTOS DE DERECHO.}

PRIMERO.- "BANCO DEL COMERCIO, S.A." demandó por los trámites del juicio declarativo de menor cuantía a don José Ángel, e interesó las peticiones que se detallan en el antecedente de hecho primero de esta sentencia.

La cuestión litigiosa se centraba principalmente en la determinación de la presencia o no de responsabilidad personal y solidaria en don José Ángel, Administrador de "Sitones, S.A., Promociones Inmobiliarias", respecto a las deudas que la misma tenía contraídas con la parte actora, dada la incidencia de acreedores que no se registraron en la contabilidad de dicha entidad, y con base en el incumplimiento del demandado de sus obligaciones de administración en relación a los datos contables, al no reflejar en la contabilidad de la compañía la imagen fiel y real de su estado económico y financiero, de las asumidas por virtud de la documentación particular entregada al Banco en el momento de concertarse el préstamo por importe de 300.000.000 de pesetas entre este y aquella en 18 de febrero de 1992, concretamente por la denominada carta de garantía obrante en las actuaciones, y no haberse procedido a la adaptación de los Estatutos a la Ley de Sociedades Anónimas antes del 30 de junio de 1992 (...). El artículo 133 de la Ley de Sociedades Anónimas establece la responsabilidad de los Administradores frente a la sociedad, los accionistas y los acreedores sociales del daño que causen por actos contrarios a la Ley, a los Estatutos o los realizados sin la diligencia con la que deben desempeñar el cargo; esta responsabilidad será exigible por acción u omisión culposa (actos contrarios a la ley o a los estatutos) o negligente (falta de diligencia debida, que, según el artículo 127 de la Ley de Sociedades Anónimas, es la de un ordenado empresario y de un representante leal), siempre que resulte daño a la sociedad, los accionistas o los terceros acreedores, y nexo entre la acción u omisión y el daño (entre otras, SSTS de 26 de

\footnotetext{
${ }^{53}$ STS de 10 de junio de 2005, Recurso 4634/1998 (ponente Román GARCía VARELA).
} 
noviembre de 1990, 11 de octubre de 1991, 21 de mayo de 1992, 26 de julio de 1994 y 31 de julio de 1996), pero dicho deber de responder solo tiene lugar cuando el Administrador actúa en su carácter de tal, esto es, como órgano social, y no si lo hace como mero socio o particular (STS de 5 de diciembre de 1991).

En el caso debatido, esta Sala no acepta los razonamientos de la sentencia recurrida sobre la inexistencia de responsabilidad del Administrador, y sienta que ha habido ocultación por don José Ángel de los datos financieros reales de la entidad prestataria al tiempo del contrato de préstamo suscrito entre "BANCO DEL COMERCIO, S.A." y "Sitones, S.A.", al no revelar con exactitud la presencia de los documentos de garantía a favor de "Banesto", cuyo conocimiento estaba obligado a proporcionar a la actora por la índole y la entidad económica de la relación contractual de referencia.

El Administrador demandado ha omitido el deber de diligencia adecuado para el ejercicio de su cargo, y ello nos lleva a la conclusión de que debe responder con la entidad codemandada de la deuda social, de conformidad con lo dispuesto en los artículos 135, 133.2 y 127 de la Ley de Sociedades Anónimas, habida cuenta de que entre las acciones y omisiones de aquel y el daño existe el correspondiente nexo de causalidad (...).

Así, declaramos la responsabilidad del demandado por su negligente actuación en las negociaciones mantenidas con la actora para la obtención de un préstamo de 300.000.000 de pesetas para la compañía de que era Administrador, como se precisa en el fundamento de derecho tercero de esta sentencia; asimismo, declaramos la responsabilidad solidaria de dicho demandado por las deudas sociales contraídas por "Sitones, S.A., Promociones Inmobiliarias" frente a la demandante, al no haber adaptado los Estatutos de esta entidad en el plazo legal, dada su condición de Administrador de esta sociedad, tal como se indica en el fundamento de derecho segundo de esta resolución; además, condenamos a don José Ángel al pago de la suma de cuatrocientos setenta mil cuatrocientos sesenta y seis euros con sesenta y ocho céntimos $(470.466,68 €)$ a "BANCO DEL COMERCIO, S.A.", cuantía que ha resultado impagada al día 17 de febrero de 1994, cuya cantidad se incrementará a partir del 17 de febrero de 1994 (fecha del reconocimiento de la deuda) con los intereses moratorios devengados y liquidados en la forma pactada en la póliza de préstamo, por consecuencia de la solidaridad en su posición deudora, y, a su vez, se reducirá en las sumas expresadas a continuación, como consecuencia de entregas recibidas de compradores de algunas de las fincas hipotecadas que han sido vendidas posteriormente por "Sitones, S.A." con la conformidad de los acreedores hipotecarios, e, igualmente, en su caso, otras cuyo resultado tenga idéntico efecto, como son: a) ciento sesenta y dos mil doscientos cincuenta y tres euros con veinte céntimos $(162.253,20 €)$, cobrados y aplicables al capital, más doce mil ciento noventa y seis euros con setenta y ocho céntimos $(12.196,78 €)$ cobrados y aplicables a reducir intereses; b) el importe en que se subrogaron unos terceros 
al adquirir dos de las fincas hipotecadas, por un montante de cincuenta mil quinientos setenta y dos euros con sesenta y siete céntimos $(50.572,67 €)$, que no procede reclamar al demandado; y c) cualesquiera otras cantidades que se acrediten satisfechas a "BANCO DEL COMERCIO, S.A." de manera similar a la expresada en los apartados a) y b)...».

II) $)^{54} \ll$ Los textos normativos del Texto Refundido de la Ley de Sociedades Anónimas que se citan establecen la necesidad de adaptar los Estatutos $\mathrm{y}$, en concreto, ajustar la cifra de capital (mediante aumento) o transformar la sociedad, antes del 30 de junio de 1992 (DT3. ${ }^{a} .1$ y 2), con la consecuencia (DT3. ${ }^{\mathrm{a}} .3$ ) de que, en caso de no haber adoptado e inscrito las medidas antes apuntadas, "los administradores y, en su caso, los liquidadores responderán personal y solidariamente entre sí y con la sociedad de las deudas sociales". A lo que añade la Disposición Transitoria 6. ${ }^{a} .2$ que "si antes del 31 de diciembre de 1995 las sociedades anónimas no hubieran presentado en el Registro Mercantil la escritura o escrituras en la que consten el acuerdo de aumentar el capital social hasta el mínimo legal, la suscripción total de las acciones emitidas y el desembolso de una cuarta parte, por lo menos, del valor de cada una de sus acciones, quedarán disueltas de pleno derecho, cancelando inmediatamente de oficio el Registrador los asientos correspondientes a la sociedad disuelta. No obstante la cancelación, subsistirá la responsabilidad personal y solidaria de los Administradores, gerentes, directores generales y liquidadores por las deudas contraídas o que se contraigan en nombre de la sociedad".

De las disposiciones citadas se desprende, con claridad, que el acuerdo de adaptación, de aumento de capital o de transformación ha de estar adoptado e inscrito en el Registro Mercantil antes del 30 de junio de 1992. Este plazo fue matizado por la Resolución de la Dirección General de los Registros y del Notariado de 18 de marzo de 1992 en el sentido de que bastaba que en 30 de junio de 1992 se hubiese solicitado la inscripción. Es la ausencia de presentación o de inscripción en el día antes indicado el hecho que genera la responsabilidad de los Administradores, a pesar de que se hayan adoptado las medidas de adaptación. Así lo viene entendiendo la jurisprudencia de esta Sala. La STS de 22 de mayo de 2006, a la que sigue la de 12 de abril de 2007, decía que del tenor literal de la DT 3. ${ }^{a}$ LSA “... se desprende con claridad que el incumplimiento de la obligación que determina la responsabilidad solidaria, entre sí y con la sociedad, de los administradores por todas las deudas sociales se produce no solamente cuando el acuerdo de adaptación de los Estatutos no se produce en el plazo establecido... sino también cuando dentro del mismo no tiene lugar válidamente la inscripción de la escritura de adaptación o al menos la correspondiente presentación en el Registro Mer-

\footnotetext{
${ }^{54}$ STS de 13 de mayo de 2008, Recurso 1333/2001 (ponente MonTES PENADÉs).
} 
cantil que dé lugar a extender el asiento de presentación, siempre que este se mantenga en vigor hasta que se produzca la inscripción definitiva..." (Doctrina que ya habían sentado las SSTS de 6 de noviembre de 1999, 14 de noviembre de 2002, 10 de junio y 3 de noviembre de 2005, entre otras).

Como el propio recurso explica, FRAPER, S.A. no había podido verificar siquiera la presentación de la escritura de transformación en 30 de junio de 1992, lo que habría de dar lugar al surgimiento de la responsabilidad de sus administradores, en los términos que previene la DT 3. a .3 LSA, situación que seguía en 31 de diciembre de 1995, por lo que fue disuelta la sociedad, en aplicación de la DT 6. ${ }^{\mathrm{a}} .2 \mathrm{LSA}$, con lo que se cancelaron los asientos correspondientes, pero, como dice el precepto, "subsiste" la responsabilidad de los administradores.

Los recurrentes se ciñen en los tres motivos a plantear una sola cuestión: la imposibilidad en que se encontraban de dar cumplimiento a las previsiones de la DT 3. ‥1 y 2 LSA, imposibilidad que, según su argumentación, les exoneraría de responsabilidad con base en el artículo 1184 CC, pues se producía "por causas ajenas a lo previsto en las Disposiciones Transitorias $3 .^{a} y$ $6{ }^{a}$ LSA". No se plantean, pues, otras cuestiones que han surgido a lo largo del debate, como el efecto de la reactivación sobre la responsabilidad de los administradores. Aunque se apunta algún tema tangente, como el de imposibilidad de aplicar la DT 6. ${ }^{\mathrm{a}}$.2 LSA a una sociedad que ya se ha transformado (por acuerdo social elevado a escritura pública, pero no inscrito) y, por ello, ya no sería "anónima", como exige el precepto. Pero este tema, además de tangente, es marginal, pues el núcleo del problema se encuentra en la falta de inscripción del acuerdo, ya protocolizado, de transformación.

En el tema aquí planteado, que es el de la imposibilidad liberatoria, no puede prosperar la tesis de los recurrentes. La jurisprudencia de esta Sala ha venido interpretando el artículo 1184, en relación con el artículo 1272, ambos del Código civil, en el sentido de una imposibilidad física o legal objetiva, duradera y no imputable al deudor, como decía la STS de 30 de abril de 2002, que citaba las de 15 de febrero y 21 de marzo de 1994, entre otras. Señalaba esta Sentencia, (con doctrina que también puede leerse en las de 20 de mayo de 1997, 7 de febrero de 1994, etc.) que la aplicación de estos preceptos ha de ser objeto de una interpretación restrictiva y casuística, atendiendo a los "casos y circunstancias" y, entre otros extremos que aquí no son relevantes, destacaba que para aplicar la imposibilidad es preciso que no haya culpa del deudor, lo que ocurre, entre otros supuestos, cuando la imposibilidad ha sido provocada por el mismo deudor (SSTS 17 de enero y 5 de mayo de 1986, 15 de febrero de 1994, etc.), lo mismo que cuando se podía conocer la causa o era previsible (SSTS 7 de octubre de 1978, 15 de febrero de 1994, 20 de mayo de 1999, etc.).

Esta doctrina excluye, en el caso, la apreciación de la imposibilidad, cuando la Nota marginal que impide la inscripción, de acuerdo con el artículo 277 del Reglamento del Impuesto de Sociedades vigente en aquel 
momento (Real Decreto 2631/1982, de 15 de octubre), obedecía a una "Baja provisional" que las Delegaciones de Hacienda podían dictar cuando los débitos tributarios de la Sociedad para con la Hacienda Pública estatal fueran declarados fallidos, o cuando no se hubiesen presentado declaraciones durante tres ejercicios consecutivos (artículo 273 del citado Real Decreto 2631/1982). La baja provisional se comunicaba al Registro (artículo 276) a través de mandamiento expedido por el Delegado de Hacienda, debiendo el Registro extender en la hoja una nota marginal (artículo 277) "en la que se expresará que si durante su vigencia se presentase algún documento para su inscripción, esta no podrá realizarse hasta que se den las circunstancias a que se refiere el artículo siguiente". La cancelación exigía (artículo 278) que la sociedad hubiera demostrado hallarse al corriente en el cumplimiento de las obligaciones tributarias.

Es claro, pues, que en el caso la imposibilidad hay que referirla a la culpa del afectado, quien dejó de atender sus obligaciones tributarias».

\section{SOBRE PLAZO DE PRESCRIPCIÓN DE LA ACCIÓN PARA EXIGIR RESPONSABILI-} DAD A LOS ADMINISTRADORES Y DETERMINACIÓN DEL TÉRMINO INICIAL PARA SU CÓMPUTO

I $)^{55} \ll$ La STS de 20 de julio de 2001 dio paso a una nueva jurisprudencia, que se encontraba ya consolidada cuando se dictó la sentencia de primera instancia, la cual, prescindiendo de la polémica -que se considera estéril- en torno a la naturaleza contractual o extracontractual de la acción de responsabilidad, se decanta por unificar dicho plazo para todos los supuestos de reclamaciones de responsabilidad de los administradores por su actividad orgánica, solución que ofrece las ventajas de aportar a esta materia un grado de seguridad jurídica que permite superar la poca precisión que en ocasiones presentan las fronteras entre la responsabilidad contractual y la extracontractual. Esta doctrina ha sido aplicada por esta Sala en SSTS de fechas 1 de marzo de 2004, 26 de mayo de 2004, 5 de octubre de 2004, 25 de marzo de 2005, 15 de julio de 2005, 22 de diciembre de 2005, 6 de marzo de 2006, 30 de enero de 2007, 21 de febrero de 2007, 30 de abril de 2008 (RC n. $\left.{ }^{\circ} 3355 / 2000\right), 3$ de julio de 2008 (RC n. $\left.{ }^{\circ} 4186 / 2001\right), 10$ de julio de 2008 (RC n. $\left..^{\circ} 4059 / 2001\right)$, entre otras (...).

Igualmente conforme a Derecho resulta la decisión de la sentencia recurrida de fijar el comienzo del plazo en el momento del cese (SSTS 26 de octubre de 2004 y 22 de diciembre de 2005, entre muchas más) el cual es un

${ }^{55}$ STS 12 de marzo de 2010, Recurso 1535/2005 (ponente XiOL Rius). En otras muchas sentencias se considera el plazo de prescripción y su cómputo de la acción de responsabilidad de administradores. Ver STS 14 de febrero de 2008, Recurso 5839/2000 (ponente MoNTES PENAdÉS). 
hecho probado que no se produjo (de la certificación del Registro Mercantil de Guadalajara resulta que el recurrente fue nombrado como administrador con carácter indefinido sin que conste su renuncia o cese), al no darse ninguna de las causas que la doctrina contempla como aptas para producirlo (la STS de 26 de octubre de 2004 menciona, en relación con las sociedades anónimas, entre muchas otras, la apertura de la liquidación de la sociedad, consecuencia automática, salvo en supuestos excepcionales, de su disolución (artículo 266 del Texto refundido de la Ley de Sociedades Anónimas), en cuanto determinante de la sustitución del administrador por los liquidadores en las actividades de gestión y representación (artículos 267 y 272 del mismo texto); o, también, la renuncia del administrador (artículo 147.1. ${ }^{\circ}$ del Reglamento del Registro Mercantil, RD 1784/1996, de 19 de julio), o su separación por decisión de la junta general (artículo 131 del Texto refundido de la Ley de Sociedades Anónimas y del 148 del Reglamento del Registro Mercantil, RD 1784/1996, de 19 de julio) (...).

QUINTO. Responsabilidad de los administradores derivada del artículo 262.5 LSA.

En relación con el sistema de responsabilidad que dimana del artículo 262.5 LSA, y los presupuestos que han de concurrir para que se dé el supuesto de hecho previsto por la norma al que se liga el efecto de hacer al administrador solidariamente responsable de las deudas contraídas por la sociedad, esta Sala se ha pronunciado en el sentido de que la acción, y por ende, la responsabilidad que prevé el artículo 262.5 LSA, es distinta en sus presupuestos y en su regulación de la contemplada en los artículos 135 y 133 LSA. Mientras la acción individual requiere que concurran los requisitos de acción u omisión culposa, daño y prueba de la relación de causalidad (STS de 11 de julio de 2008, RC n. ${ }^{\circ}$ 3675/2001), la acción del 262 LSA tiene un carácter abstracto o formal (STS de 26 de junio de 2006), cosa que se expresa en algunas sentencias atribuyéndole una naturaleza objetiva o cuasi objetiva (SSTS de 25 de abril de 2002, 14 de noviembre de 2002, 6 de abril de 2006 [Pleno], 28 de abril de 2006 y 26 de mayo de 2006, entre otras). De esto se sigue que su declaración no exige la concurrencia de más negligencia que la consistente en omitir el deber de promover la liquidación de la sociedad mediante convocatoria de la Junta o solicitando que se convoque judicialmente cuando sea el caso -y ahora también mediante solicitud de la declaración de concurso, cuando concurra su presupuesto objetivo-. No se exige, pues, una negligencia distinta de la prevista en la LSA (STSS de 20 y 23 de febrero de 2004 y de 28 de abril de 2006). Tampoco es menester que se demuestre la existencia de una relación de causalidad entre el daño y el comportamiento del administrador, sino que la imputación objetiva a este de la responsabilidad por las deudas de la sociedad se realiza ope legis [por ministerio de la ley] (SSTS de 28 de abril de 2006, 31 de enero de 2007, 10 de julio de 2008, RC n. ${ }^{\circ} 4059 / 2001$, y 11 de julio de 2008, RC n. $\left.{ }^{\circ} 3675 / 2001\right)$. 


\section{II $)^{56}$ «FUNDAMENTOS DE DERECHO.}

PRELIMINAR.- 1.- El litigio.- La demanda se basaba, según se ha visto, en el incumplimiento del contrato suscrito en 12 de febrero de 1992 entre DIPSA y la actora, así como en posterior incumplimiento de la obligación de finalizar la construcción y entregar a la demandante, antes de 16 de marzo de 1995, un apartamento con plaza de garaje en la Urbanización que se ha indicado. La pretensión básica se dirige a que se declare resuelto el contrato de compraventa, condenando a la entidad demandada y, con ella, solidariamente, a sus administradores y a otras sociedades del grupo, por aplicación de la doctrina del levantamiento del velo, al pago de la cantidad demandada en concepto de devolución del precio pagado por la compra, más daños y perjuicios (...).

2.- La instancia.-

La Sentencia de Primera Instancia desestimó la demanda, con absolución de los demandados e imposición de las costas (...).

La Audiencia Provincial estimó el recurso, revocó la sentencia apelada y estimó la demanda, por lo que condenó a DIPSA, y a sus administradores sociales D. ${ }^{a}$ Celestina, D. Arcadio, D. Bienvenido y D. Evelio, solidariamente, a pagar la cantidad de 75.633.200 pesetas $(454.564,69 €)$, más el interés legal correspondiente, que se determinará en ejecución de sentencia, imponiendo las costas causadas en la primera instancia a dichos demandados, y confirmando el resto de los pronunciamientos absolutorios de la primera instancia. (...).

[YA EN CASACIÓN] Ambos motivos han de ser desestimados.

La Sala de instancia aplica correctamente el artículo 949 del Código de Comercio, precepto que rige el tema de la prescripción de las acciones de responsabilidad de los Administradores, tanto en el caso de las acciones a que se refieren los artículos 133 a 135 LSA cuanto los supuestos de la responsabilidad de los artículos 262.5 en relación con el 260.1 de la LSA, según ha establecido, ya con claridad y de modo consolidado, la jurisprudencia de esta Sala (SSTS 26 de octubre de 2007, que recoge otras anteriores, como las de 26 de mayo de 2004, 22 de marzo, 13 y 22 de diciembre de 2005, 2 de febrero, 6 y 9 de marzo, 23 y 26 de junio, 9 y 27 de octubre y 28 de noviembre de 2006, 13 de febrero, 8 y 14 de marzo de 2007, 5 de marzo de 2009, etc.). Esta responsabilidad nace desde que, producido el conocimiento de la situación de insolvencia o de la concurrencia de alguna de las causas de disolución a que se refieren los apartados $3 .^{\circ}, 4 .^{\circ}, 5^{\circ}$ o $7 .^{\circ}$ del artículo 2601.1 LSA, han transcurrido los plazos que señalan los artículos 262.2, 262.4 y 262.5 LSA sin que se haya verificado la promoción de la Junta, de

${ }^{56}$ STS de 12 de junio de 2009, Recurso 2352/2004 (Ponente Montes PEnAdÉs). Este ponente acostumbra sistematizar el contenido de la sentencia de una forma muy clara y didáctica). 
la disolución judicial o del concurso (según el texto actualmente en vigor) en los términos que allí se señalan, y prescribe a los cuatro años del cese, por cualquier causa, como Administradores, como dispone el artículo 949 del Código de Comercio, computándose desde la inscripción de su cese en el Registro Mercantil (SSTS 13 de abril de 2000, 2 de abril de 2002, 26 de mayo de 2006, etc.), doctrina que ha de entenderse (SSTS 26 de mayo y 26 de junio de 2006, 5 de marzo de 2009, etc.) en el sentido de que la imposibilidad de oponer a terceros de buena fe el cese de los Administradores por falta de inscripción en el registro Mercantil no exime de la concurrencia de los demás presupuestos exigidos por la jurisprudencia para la existencia de dicha responsabilidad».

III) ${ }^{57}$ Sobre falta de inscripción en el Registro Mercantil del cese del administrador y término inicial del plazo de prescripción de la acción de responsabilidad ex art. 262.5 LSA.

«Como tiene señalado esta Sala (Sentencias de 13 de abril de 2000, 2 de abril de 2002, 26 de mayo de 2006, etc.) en relación con la responsabilidad de los administradores prevista en el artículo 262.5 LSA, el momento para determinar la extensión de la responsabilidad de los Administradores por las deudas sociales es el de la inscripción de su cese por cualquiera de las causas legalmente establecidas en el Registro Mercantil, ya que tanto cuando el cese se produce por expiración del plazo, como cuando ocurre por separación o renuncia, se ha de inscribir (artículos 145, 147 y 148 del Reglamento del Registro Mercantil) en garantía de terceros que hayan de confiar en su contenido. Esta doctrina debe entenderse, según las Sentencias de 26 de mayo y 26 de junio de 2006, en el sentido de que la imposibilidad de oponer a terceros de buena fe el cese de los Administradores por falta de inscripción en el Registro Mercantil (artículo 21.1 en relación con el artículo 22.2, ambos del Código de Comercio) no exime de la concurrencia de los demás presupuestos exigidos por la jurisprudencia para la existencia de dicha responsabilidad. De lo que se deriva que la falta de inscripción en el Registro Mercantil del cese del Administrador no comporta por sí misma la ampliación del lapso temporal en el que deben estar comprendidas las acciones u omisiones determinantes de responsabilidad, toda vez que se requerirá una acción u omisión del Administrador, realizado con malicia, negligencia grave o ejercicio abusivo de sus facultades, daño en el patrimonio de los socios o de terceros, y relación causal entre uno y otro. Una acción u omisión que el Administrador de que se trate habrá podido realizar o no, según la situación en que de facto se encuentre, independientemente de que haya accedido o no su cese al Registro Mercantil. Ahora bien, el efecto que debe atribuirse a la falta de inscripción del cese del Administrador en el Registro Mer-

${ }^{57}$ STS 1 de abril de 2009, Recurso 2198/2003 (Ponente Montes PenAdÉs). 
cantil, a efectos del cómputo del plazo de prescripción de la acción tendente a exigir su responsabilidad, es el de no poderse iniciar el cómputo del plazo de prescripción (de cuatro años, de acuerdo con el artículo 949 Ccom.), sin perjuicio de los efectos que pueda producir el conocimiento del cese efectivo del Administrador por parte de quien ejercita la acción o la acreditación de la mala fe con que actúa en el caso. Esto es que, en definitiva, no cabe oponer a terceros de buena fe el transcurso del plazo de prescripción del artículo 949 CCom. desde el momento de un cese que no se ha inscrito en el Registro, sin perjuicio de que haya que considerar la posibilidad de actuación del Administrador como elemento del supuesto lesivo o, desde luego, la carencia de buena fe de quien ejercita la acción».

IV $)^{58}$ «A) Respondiendo a la primera cuestión, relativa a la determinación del plazo de prescripción de las acciones de responsabilidad de los administradores, y siendo indiscutido que la acción ejercitada fue la acción individual de responsabilidad y no la acción de responsabilidad solidaria por incumplimiento de las obligaciones de los administradores de promover la disolución de la sociedad, se hace imprescindible aclarar que las sentencias citadas por los recurrentes en pro del plazo anual plasman una anterior y ya superada doctrina que entendía, en línea con la tesis casacional esgrimida, que el plazo de prescripción de cuatro años del artículo 949 del Código de Comercio era solo aplicable a responsabilidades derivadas de la gestión social o de la representación, pero no a la responsabilidad civil del artículo 1902 del Código Civil, responsabilidad subjetiva por daños derivados de actuación culpable o negligente, a la que alude el artículo 135 LSA (aplicable a las limitadas por remisión del 69.1 de la L.S.R.L), de carácter extracontractual, que por ello ha de someterse al plazo de prescripción de un año del artículo 1968.2. ${ }^{\circ}$ del Código Civil (por remisión del artículo 943 del de Comercio), favoreciendo ese criterio jurisprudencial el hecho de que, por estar cada clase de acción sujeta a diferente plazo prescriptivo, cobraba sentido analizar el tipo o clase de responsabilidad concreta que se venía demandando. Sin embargo, ya en la fecha en que se pronunció la sentencia impugnada, esta Sala en Sentencia de 20 de julio de 2001 tuvo la ocasión de poner fin a cierta fluctuación que se había venido registrando en sus sentencias en torno al plazo de prescripción aplicable a las acciones de responsabilidad de los administradores sociales, entendiendo, con designio de unificación de doctrina, que el plazo de las individuales, que se funden en el artículo 135 L.S.A., debe ser también el de cuatro años que establece el artículo 949 del Código de Comercio, prescindiendo de la polémica -que se considera estéril- en torno a la naturaleza contractual o extracontractual de la acción mencionada, unificando en definitiva dicho plazo, para todos los supuestos

${ }^{58}$ STS de 3 de julio de 2008, Recurso 4186/2001 (ponente Almagro NosETE). 
de reclamaciones de responsabilidad de los administradores por su actividad orgánica, lo que ofrece las ventajas de aportar a esta materia un grado de seguridad jurídica que permite superar la poca precisión que en ocasiones presentan las fronteras entre la responsabilidad contractual y la extracontractual. Esta doctrina ha venido siendo aplicada desde entonces por esta Sala en sentencias de fechas 1 marzo, 26 de mayo y 5 octubre 2004, 25 de marzo, 15 junio y 22 de diciembre de 2005, 2 de febrero, 6 marzo y 26 de mayo de 2006, 30 de enero, 21 de febrero, 8, 12 y 14 de marzo y 14 de mayo de 2007, por citar algunas de entre las más recientes, lo cual permite descartar la vulneración que se denuncia.

B) Sentado que el plazo de prescripción aplicable es el de cuatro años, procede entonces concretar cuándo ha de comenzar a computarse el mismo.

Afirma la parte recurrente, amparándose en el tenor literal del artículo 949 del Código de Comercio, que el dies a quo es aquel en que los administradores cesaron "por cualquier motivo" en el desempeño de su cargo, lo que, según dicen, reiterando los argumentos esgrimidos al contestar a la demanda (folios 151 y 280 de las actuaciones), tuvo lugar el día 27 de octubre de 1992, en que renunciaron voluntariamente a su cargo, y la Junta acordó su separación, sin perjuicio de que la inscripción en el Registro Mercantil se demorase hasta el 25 de febrero de 1993. En síntesis, si, como apunta la tesis de la parte recurrente, el día inicial del plazo a todos los efectos, inclusive frente a terceros acreedores de buena fe, se fija en el momento en que dimitieron, y se aceptó por la Junta General su dimisión, la acción estaría prescrita, lo que no ocurriría si el cómputo arranca cuando el cese se inscribió en el Registro, todo lo cual circunscribe la controversia a la cuestión, meramente procesal, de determinar cuál es el efecto que debe atribuirse a la falta de inscripción en el Registro Mercantil del cese del administrador a efectos del cómputo del plazo de prescripción de la acción tendente a exigir su responsabilidad.

La solución a esta disyuntiva pasa, en primer lugar, por recordar la doctrina expuesta en la sentencia de 18 de febrero de 2007, que es traída a colación por la más reciente de 14 de mayo de 2007. Según esta línea jurisprudencial -que parte de que la fijación del dies a quo es una cuestión de hecho, lo que no es obstáculo para revisar en casación su determinación cuando la valoración hecha por la Sala de instancia aparezca como incongruente, absurda o arbitraria (Sentencia de 6 de marzo de 2006)-, el momento establecido en el artículo 949 C.Com como dies a quo para el ejercicio de la acción de responsabilidad dirigida contra los administradores de la sociedad es el de su cese (Sentencia de 14 de mayo de 2007, con cita de las de 26 de mayo de 2006 y 22 de marzo de 2007, entre las más recientes), lo que ha de entenderse como aquel en que, como señala el precepto, "por cualquier motivo" hubieran cesado en "el ejercicio de la administración", siendo por ello que, como destacó la sentencia de 26 de octubre de 2004, el inicio del cómputo de ese plazo reclama un cese propiamente dicho del administrador 
demandado, por más que la causa de aquel pueda ser cualquiera de las que se consideran aptas para producirlo, «entre ellas, la apertura de la liquidación de la sociedad, consecuencia automática, salvo en supuestos excepcionales, de su disolución (artículo 266 del Texto refundido de la Ley de Sociedades Anónimas), en cuanto determinante de la sustitución del administrador por los liquidadores en las actividades de gestión y representación (artículos 267 y 272 del mismo texto); o, también, la renuncia del administrador (artículo 147.1. ${ }^{\circ}$ del Reglamento del Registro Mercantil, RD 1.784/1996, de 19 de julio); o su separación por decisión de la junta general (artículo 131 del Texto refundido de la Ley de Sociedades Anónimas y del 148 del Reglamento del Registro Mercantil, RD 1.784/1996, de 19 de julio)». Según esta doctrina, que admite que se tenga por producido el cese del administrador en el desempeño de su cargo por cualquiera de las causas que contempla el Reglamento del Registro, parecería que la dimisión por parte de los recurrentes, señores Francisco y Valentín, con fecha 27 de octubre de 1992, que fue aceptada por la Junta, por acuerdo de esa misma fecha, elevado a público en escritura notarial otorgada por el Notario Don Ángel Benítez Donoso Cuesta (folios 164 y siguientes), debería conllevar la fijación del dies a quo en ese instante. Así sería, sin lugar a dudas, si el mencionado cese estuviera revestido de la publicidad formal que garantiza la inscripción registral, pues en ese caso, a partir de ese momento el legitimado para ejercitar la acción, aun presumiéndose su buena fe, no podría negar su desconocimiento. Lo contrario ocurre cuando, como acontece en el caso de autos, el cese accede al registro en fecha posterior al momento en que tuvo lugar el acto de separación, pues solo a partir de la inscripción pueden ser oponibles a terceros de buena fe los efectos o las consecuencias de la separación del cargo, habida cuenta además, de que la buena fe se presume, y que no corresponde al actor probar que no pudo conocer de otro modo el cese, sino que, al contrario, es obligación del que sostiene la eficacia del cese no inscrito demostrar que el afectado tuvo conocimiento del momento en que se produjo el cese efectivo por parte del administrador, o acreditar de otro modo su mala fe, lo que no ha ocurrido. Esta es la línea en que se pronuncia la Sentencia de 26 de junio de 2006, que distingue entre los efectos que, en el orden sustantivo puede derivar de la ausencia de inscripción del cese en cuanto a la pervivencia y extensión temporal de la responsabilidad del administrador cesado, y los efectos en el plano procesal, que esa falta de inscripción origina en cuanto al cómputo del plazo de prescripción, -que es lo de lo que aquí se trata-.

a) En el plano sustantivo, «relativo al tiempo en que se mantiene la responsabilidad del administrador», señala la Sentencia que la falta de inscripción en el Registro Mercantil del cese del administrador «no comporta por sí misma la ampliación del lapso temporal en el que deben estar comprendidas las acciones u omisiones determinantes de responsabilidad, pues la imposibilidad de oponer a terceros de buena fe los actos no inscritos en el 
Registro Mercantil (artículo 21.1 CCom, en relación con el artículo 22.2 CCom) no excusan de la concurrencia de los requisitos exigibles en cada caso para apreciar la responsabilidad establecida por la ley. Únicamente cabe admitir que la falta de diligencia que comporta la falta de inscripción puede en algunos casos, especialmente en supuestos de ejercicio de la acción individual del artículo 135 LCA, constituir uno de los elementos que se tengan en cuenta para apreciar la posible existencia de responsabilidad, dado que la ausencia de inscripción pueda haber condicionado la conducta de los acreedores o terceros fundada en la confianza en quienes creían ser los administradores y ya habían cesado». En otras palabras, lo que viene a decir esta doctrina respecto del carácter no constitutivo de la inscripción, y en cuanto a que ha de estarse por ello al cese efectivo en orden a fijar la responsabilidad del administrador, es que solo cabe extender su responsabilidad a los actos que tengan lugar hasta ese momento en que cesó válidamente, no pudiendo los terceros de buena fe ampararse en la falta de inscripción para demandar responsabilidades derivadas de actos ocurridos después del cese y antes de su plasmación registral. Sin embargo, como veremos a continuación, las consecuencias de la falta de inscripción frente a terceros son otras cuando de fijar el día inicial para el cómputo del plazo de prescripción se trata.

b) En el plano procesal, sigue diciendo la referida Sentencia de 26 de junio de 2006, «distinto es el efecto que debe atribuirse a la falta de inscripción en el Registro Mercantil del cese del administrador a efectos del cómputo del plazo de prescripción de la acción tendente a exigir su responsabilidad. Debe entenderse que, si no consta el conocimiento por parte del afectado del momento en que se produjo el cese efectivo por parte del administrador, o no se acredita de otro modo su mala fe, el cómputo del plazo de cuatro años que comporta la extinción por prescripción de la acción no puede iniciarse sino desde el momento de la inscripción, dado que solo a partir de entonces puede oponerse al tercero de buena fe el hecho del cese y, en consecuencia, a partir de ese momento el legitimado para ejercitar la acción no puede negar su desconocimiento».

La aplicación de esta doctrina determina, en buena lógica, que no pueda declararse prescrita la acción promovida en la demanda -si bien por razones distintas de las que fueron tomadas en consideración por la Sala de apelación, que, tras descartar como fecha de inicio del término prescriptivo el de la sentencia de condena, se decanta por el momento en que la actora conoció el evento dañoso del que trae causa su pretensión, esto es, cuando conoció de la desaparición de facto de Suelo Urbano, la acción pudo ejercitarse-, pues tomando como día inicial del cómputo el día 25 de febrero de 1993, que es la fecha del asiento registral, la demanda se presenta antes de que expire el plazo de cuatro años previsto por la ley (24 de enero de 1997)». 
E. SOBRE LAS DIFERENCIAS DE RÉGIMEN JURÍDICO EXISTENTES ENTRE LA ACCIÓN DE RESPONSABILIDAD INDIVIDUAL DEL ART. 135 L.S.A Y LA RESPONSABILIDAD OBJETIVA (O CUASI OBJETIVA) DEL ART. 262.5 L.S.A.

I) ${ }^{59} \ll$ FUNDAMENTOS DE DERECHO.

PRIMERO.- D. ${ }^{\mathrm{a}}$ Herminia presentó demanda contra D. Leopoldo y otros en reclamación de la cantidad de 44.432 .545 pesetas, más intereses legales desde el 2 de septiembre de 1996. Se solicitaba que los demandados fueran condenados solidariamente al pago como Administradores de la compañía mercantil UNIÓN Y GESTIÓN FINANCIERA, S.A. (UGF) por razón de que tenían el deber de disolver la sociedad, que se encontraba en causa de disolución al hallarse en estado de insolvencia, habiendo cesado en toda actividad y estando desaparecida de su domicilio social, en base a la responsabilidad prevista en el artículo 262.5 LSA. La demanda fue repartida al Juzgado e Primera Instancia n. ${ }^{\circ} 63$ de los de Madrid, dando lugar al Juicio de Menor Cuantía 863/1997.

La mayor parte de los demandados fueron declarados en rebeldía. Solo dos de ellos, los Sres. Juan Francisco y Teófilo sostuvieron el litigio.

Los demandados opusieron las excepciones de prescripción, señalando que habían cesado en enero de 1994 y en febrero de 1995, respectivamente.

El Sr. Teófilo formuló reconvención, para que se declarara que la actora actuaba con abuso del derecho al pretender cobrar la cantidad que ahora reclama cuando ya había sido reclamada en un litigio anterior frente a las antiguos administradores de la sociedad, que entonces se denominaba CMO, S.A., SOCIEDAD DE VALORES y frente Sres. Emiliano, Jenaro y Roman, habiendo sido estimada por el Juzgado de Primera Instancia de San Sebastián n. ${ }^{\circ} 4$, en Autos de Juicio de Menor Cuantía n. ${ }^{\circ}$ 439/97.

En realidad, se trata del tercer litigio entablado por D. ${ }^{a}$ Herminia en reclamación de la indicada cantidad (...).

SEGUNDO.- La Sentencia de primera instancia, dictada en 31 de mayo de 2001 (...) desestima la demanda, con costas. Y desestima la reconvención (...).

La Sentencia de apelación, dictada en 21 de mayo de 2004 por la Audiencia Provincial de Madrid, (...) desestimó el recurso...

TERCERO.- El recurso interpuesto por el Sr. Teófilo presenta un Único motivo, en el que se denuncia la infracción del artículo 7 del Código civil, en sus apartados 1 y 2, y la de los artículos 11.2 LOPJ y 247, ap. 1,2 y 3, de la LEC (...).

Esta Sala ha distinguido entre las acciones de responsabilidad individual de los Administradores, basadas en los artículos 133 y 135 LSA, y las que se dirigen a establecer la responsabilidad especial que impone a los administradores el artículo 262.5 de la propia LSA por no promover la liquidación (o,

${ }^{59}$ STS de 1 de junio de 2009, Recurso 2704/2004 (ponente MonTes PenAdÉs). 
en los términos de la actual redacción, el concurso) de la sociedad. Son acciones que se tienen por distintas, aunque puedan ser acumuladas (SSTS 17 de octubre y 30 de noviembre de 2005,9 y 22 de marzo y 23 de junio de 2006, 14 de marzo de 2007, 15 y 25 de marzo de 2009, etc.) ya que, en régimen de concurso ideal, cuando la insolvencia de la sociedad provocada por la negligencia de los administradores causa una lesión directa a los acreedores se puede dar paso a la responsabilidad individual, que comprende la acción y la omisión (SSTS 11 de octubre de 1991, 10 de diciembre de 1996, 11 de noviembre de 1997, 17 de diciembre de 2003, 20 de febrero de 2004, 14 de marzo de 2007, etc.). No se puede aceptar, pues, que la ahora recurrida haya ejercitada la misma acción en este litigio que en el pleito anterior, como se expone el Fundamento Jurídico de esta Sentencia (...).

No puede aceptarse, finalmente, que la actuación de la ahora recurrida, en el ejercicio legítimo de su derecho, aun cuando es cierto que presenta la demanda que da lugar a este litigio antes de que haya recaído sentencia firme en el anterior, pero cuando su pretensión había sido ya desestimada por la Audiencia Provincial de Guipúzcoa, sea contraria a la buena fe, sino que se trata de un comportamiento justo, leal, honrado y lógico (SSTS 2 de octubre de 2000, 22 de febrero de 2001 , etc.) en todo caso orientado por los valores de lealtad y probidad (SSTS 20 de junio de 2006, 3 de enero de 2007, etc.) toda vez que tiene a su disposición la posibilidad de reclamación de la cantidad adeudada en base a la responsabilidad ex artículo 262.5 LSA. Otra consideración podría merecer, que hubiera recaído condena de los demandados en el litigio anterior, y aún entonces se habría de determinar si eran los mismos demandados y si se intentaba ejecutar ambas condenas. Pero tal y como se han producido los acontecimientos, el ejercicio del derecho en el caso no sobrepasa los límites del derecho que se ejercita ni incide en una desviación del poder (SSTS 14 de mayo de 2002, 28 de enero de 2005, 21 de septiembre de 2007, etc.) (...).

[SOBRE LA PRESCRIPCIÓN] El motivo se desestima, pues es doctrina consolidada de esta Sala que la prescripción de las acciones de responsabilidad contra los administradores de las sociedades se rige por el artículo 949 del Código de comercio, regla especial que ha de ser aplicada con preferencia a las reglas generales, entre las cuales las que cita el recurrente, y que el plazo de cuatro años se ha de computar, como señala el indicado precepto del Código de Comercio, desde el momento en que, por cualquier motivo, se cese en la administración (SSTS 26 de octubre de 2007, que recoge muchas otras anteriores, como las de 26 de mayo de 2004, 22 de marzo, 13 y 22 de diciembre de 2005, 2 de febrero, 6 y 9 de marzo, 23 y 26 de junio, 9 y 27 de octubre y 28 de noviembre de 2006, 13 de febrero, 8 y 14 de marzo de 2007, doctrina que también se recoge en la STS de 1 de abril de 2009, etc.). El recurrente sostuvo la condición de administrador hasta enero de 1994, inscribiéndose su cese en el Registro Mercantil en julio de 1994 (Fundamento Jurídico Tercero de la Sentencia recurrida), y la demanda se presentó en 1997 (...)». 


\section{II $)^{60}$ «FUNDAMENTOS DE DERECHO.}

TERCERO.- Los motivos segundo y cuarto del recurso de casación mantienen la responsabilidad de los demandados que deriva de los artículos 127, 133.1 y 135 de la Ley de Sociedades Anónimas; alegan la infracción de estos artículos, el segundo y la del artículo 1253 del Código civil relativo a la prueba de presunciones, el cuarto.

Tal responsabilidad es de carácter subjetivo, deriva de la falta de diligencia en el desempeño del cargo de administrador (así, sentencias de 24 de diciembre de 2002 y 18 de septiembre de 2003) y requiere la prueba "no sólo de la acción u omisión dolosa o culposa del administrador y el daño causado, sino también del nexo causal entre ambos", como reitera la sentencia de 25 de febrero de 2002, que se corresponde con la llamada responsabilidad extracontractual, como dice la sentencia de 14 de noviembre de 2002: "es necesario que se cumplan los supuestos exigidos en el artículo 1902 del Código civil para poder exigir esta clase de responsabilidasd extracontractuales"; y añade la de 6 de marzo de 2003 que esta "acción no es de responsabilidad por deuda, sino resarcitoria de daño, por lo que no nacería con el mero incumplimiento contractual...".

Las sentencias de instancia han negado explícitamente la falta de diligencia de los administradores, han resaltado la crisis económica que fue causa del impago, del que deduce la sociedad demandante la negligencia y han negado también la falta de relación de causalidad entre la actuación de los mismos y del daño sufrido por tal impago a dicha sociedad. Por tanto, se debe desestimar el motivo segundo.

La sentencia objeto de este recurso de casación emplea una expresión que, a primera vista, confunde; dice "no ha quedado acreditado que la industria GALYCA, S.A. desconociera la situación patrimonial de PREFEXSA..." por lo que parece invertir la carga de la prueba y llegar a una presunción de que conocía tal situación patrimonial. Pero en las líneas siguientes deja claro que estima probado el hecho, inamovible en casación, de que la sociedad demandante conocía o al menos tenía dudas de la situación patrimonial de la sociedad que, al no cumplir su obligación de pago, ha provocado el ejercicio de la acción de responsabilidad de los administradores. Pero no solo esto, sino que este conocimiento no es el único, ni mucho menos, que acredita que no concurre el presupuesto esencial de falta de diligencia para que prospere la acción ex artículo 133 y 135 de la Ley de Sociedades Anónimas. Por ello, no aparece infracción del artículo 1253 del Código civil y el motivo se desestima.

CUARTO.- El primero de los motivos del recurso de casación, que se trata aquí en último lugar y la parte recurrente plantea con carácter principal, se refiere a la acción de responsabilidad de los administradores de la Socie-

${ }^{60}$ STS de 28 de mayo de 2005, Recurso 4720/1998 (ponente O’CALlAGHAN MuÑOZ). 
dad Anónima que establece la ley en el artículo 262.5 en relación con los artículos 262.1, 260.4 y 260.5, que los responsabiliza, de manera objetiva (así, sentencia de 23 de diciembre de 2003, que dice: "Hay que partir de que, como reitera la sentencia de 20 de octubre de 2003, es una responsabilidad objetiva, que no se evita con una alegación de diligencia, ni, mucho menos, con el argumento de que no hubo culpa; cuya responsabilidad ha destacado la sentencia de esta Sala de 16 de julio de 2002 que los considera autores de una conducta antijurídica; a los que se impone una responsabilidad sanción, como añade la de 18 de septiembre de 2003; y, como decía la de 14 de noviembre de 2002, la acción cuyo soporte estriba en el $n .{ }^{\circ} 5$ del art. $262 \mathrm{del}$ Texto Refundido de la Ley de Sociedades Anónimas de 22 de diciembre de $1989 . .$. para su éxito no es necesario que concurran los supuestos de la culpa, como se tiene reiteradamente manifestado en la jurisprudencia de esta Sala, entre otras, en las sentencias de 20 de diciembre de 2000, 20 de abril de 2001, 26 de octubre de 2001 y 25 de abril de 2002") cuando no han promovido la disolución de la sociedad, en caso de descapitalización de la misma, en el plazo de dos meses».

\section{$\mathrm{F}^{61}$. SOBRE CONCURRENCIA O CONCURSO DE ACCIONES PROMOVIDAS CON FUN- DAMENTO EN EL ART. 133 Y EN EL ART. 262.5, AMBOS DE LA L.S.A.}

«La Jurisprudencia de esta Sala ha admitido que, en régimen de concurso ideal, la situación de insolvencia de una sociedad en la que los administradores han incumplido su obligación de promover la disolución, además de ser determinante de la responsabilidad a que se refiere el artículo $262.5 \mathrm{LSA}$, pueda dar paso a la responsabilidad individual, por la vía de la acción llamada "individual" del artículo 135 LSA, cuando la insolvencia de la sociedad provocada por la negligencia de los administradores causa una lesión directa a los acreedores (SSTS 11 de diciembre de 1991, 10 de diciembre de 1996, 11 de noviembre de 1997, 17 de diciembre de 2003, 20 de febrero de 2004, 27 de octubre de 2006, etc.) pues, como decía la STS 14 de marzo de 2007, la responsabilidad por los actos de los administradores comprende la acción y la omisión. Además, como admiten las SSTS 17 de octubre y 30 de noviembre de 2005, 9 y 22 de marzo y 23 de junio de 2006, etc., las acciones dirigidas a exigir la responsabilidad ex artículo 135 y ex artículo 262.5 LSA puede ser acumuladas y no incurre en incongruencia la sentencia que fija, como determinante de la responsabilidad, no el invocado artículo 135 LSSA sino el 262 LSA, "siempre que concurran los requisitos de la acción individual de responsabilidad y los hechos en que se funda hayan sido alegados por la parte (SSTS 28 de septiembre de 2006)"».

${ }^{61}$ STS de 30 de mayo de 2008, Recurso 1219/2001 (ponente MonTes PEnAdÉs). En esta sentencia, además, se vuelve sobre el frecuente asunto de la prescripción. 


\section{$\mathrm{G}^{62}$. SOBRE EJERCICIO DE LA ACCIÓN INDIVIDUAL DE RESPONSABILIDAD Y SUBSI- DIARIAMENTE LA DEL ART. 262.5 L.S.A.}

\section{«FUNDAMENTOS DE DERECHO.}

PRIMERO.- I.- El debate.-

A.- La actora relata en la demanda:

1.- Que suministraba materiales férricos a la demandada "Ferrallas Perosanz, S.A.", que fue primero una Sociedad Anónima Laboral. Ante el impago de varias partidas, promovió juicio ejecutivo que se siguió ante el Juzgado de Primera Instancia de Aranda de Duero n. ${ }^{\circ} 1$ (73/97) y finalizó por sentencia que condenaba a "Ferrallas" al pago de 7.249.756 pesetas, más intereses y costas. Pero nada pudo cobrar la actora ante la insolvencia de la demandada, que carecía de actividad y de patrimonio. La deuda total asciende a la cantidad de 12.433 .651 pesetas.

2.- En la Junta General Universal de 5 de noviembre de 1992 se acordó en nombramiento de D. Franco y D, Luis Enrique como miembros del Consejo de Administración. Los Sres. Luis Enrique y Franco eran propietarios de la sociedades HIESCOSA e INHERCU, sociedades a las que se transfirió el patrimonio de "Ferrallas".

B.- Los demandados alegan:

1.- Falta de litisconsorcio pasivo necesario al no haberse demandado a D. Diego, Presidente Ejecutivo de "Ferrallas" a quien consideran "factor y gestor" del entramado de relaciones comerciales.

2.- Que los Sres. Luis Enrique y Franco accedieron al Consejo de "Ferrallas Perosanz" en 5 de noviembre de 1992 al haber adquirido el 37,3\% del capital, y cesaron en 27 de mayo de 1994, fecha en la que asumió el Sr. Diego la condición de Administrador Único, y tras esa fecha se renovaron las letras de cambio que fueron reclamadas en el juicio ejecutivo. "Ferrallas" entró en grave crisis económica y de liquidez en los primeros meses de 1994 (...).

La entidad actora ejercita la llamada acción individual de responsabilidad, que se prevé en el artículo 135 LSA, y subsidiariamente la acción que se previene en el artículo $262.5 \mathrm{LSA}$, texto vigente antes de las sucesivas reformas operadas por las Leyes Concursal (Ley 22/2003 de 9 de julio) y Ley 19/2005, de 14 de noviembre, para exigir que los administradores respondan solidariamente de las obligaciones sociales si incumplen las obligaciones de promover la disolución, convocando al efecto la Junta General o solicitando la disolución judicial. Los Juzgadores de instancia consideraron acreditada la existencia de la deuda cuya reclamación había resultado fallida, ante la absoluta despatrimonialización de la sociedad deudora, constataron el perjui-

${ }^{62}$ STS de 27 de octubre de 2006, Recurso 5337/1999 (ponente MonTES PENADÉs). 
cio irrogado e identificaron el procedimiento por el cual se había llegado a la situación que había provocado el daño, señalando que consistía en la transmisión, en pago de unos créditos no vencidos ni exigibles, que se califican, además, de "supuestos", de los activos de la sociedad deudora a dos sociedades, dedicadas al mismo giro o tráfico, que administran los codemandados, también administradores hasta ese momento de la deudora, subrayando el ánimo fraudatorio con que se realizó la operación.

Uno de los medios de defensa que utilizan los codemandados, al que específicamente nos estamos refiriendo, consiste en señalar que nos encontramos ante un supuesto de responsabilidad extracontractual, y que la acción ejercitada estaría prescrita por aplicación del artículo 1968.2 CC. Pero esta Sala, no obstante considerar que en el caso de las dos acciones ejercitadas nos encontramos ante un supuesto de responsabilidad extracontractual (Sentencias de 4 y de 24 de abril de 2006) ha venido aplicando, desde la Sentencia de 22 de junio de 1995, la regla especial de prescripción que se contiene en el artículo 949 CCom. respecto de "la acción contra los socios gerentes y administradores de las compañías o sociedades". Prima el carácter especial de la regla, ya que, como es sabido, en buena técnica de aplicación del Derecho la regla especial tiene preferencia sobre la general siempre que, como ocurre en el caso, el supuesto de hecho se contenga dentro de las previsiones de la norma especial.

TERCERO.- En el segundo de los motivos del recurso presentado por D. Luis Enrique, por la vía del ordinal 4. ${ }^{\circ}$ del artículo 1692 LEC 1881, se denuncia la infracción, calificada como "interpretación errónea" del artículo 133 LSA en relación con los artículos 135 y 260.5. ${ }^{a}$ de la misma Ley de Sociedades Anónimas.

El fondo del motivo se encuentra en la inexistencia de una relación de causalidad -a juicio del recurrente- entre el daño causado y la actuación del ahora recurrente, que se apoyaría en la renovación de efectos con posterioridad al cese del recurrente como administrador, pero apunta también a que "Ferrallas Perosanz, S.A." continuó las relaciones. Coincide ello, al menos en buena parte, con lo alegado en el Motivo Cuarto del Recurso presentado por D. Franco, en el que, por el mismo cauce procesal, se denuncia también la infracción de los artículos 133 y 135 LSA, a los que añade más tarde el artículo 127 LSA, que se considera inaplicado. Señala este recurrente que no se ha probado la situación de insolvencia, que no hay relación de causalidad, y apunta que la responsabilidad, de haberla, alcanzaría la cifra que después de la liquidación quedara sin cubrir en base al patrimonio de la sociedad.

Se procede al examen conjunto de los motivos, dada su conexidad. Ambos motivos han de ser desestimados. En primer lugar, inciden de una manera notoria y manifiesta en el vicio procesal conocido como "hacer supuesto de la cuestión", dando por probado lo que la Sala no estima como tal, sin haber utilizado los remedios de que dispone para demostrar la apreciación errónea o infundada de la Sentencia recurrida, como el error de Dere- 
cho en la apreciación de la prueba, con cita de la norma valorativa infringida o la alegación de error notorio o grosero, irrazonabilidad o arbitrariedad, en base a la jurisprudencia del Tribunal Constitucional, tales como 37/1982, 68/1983, 24 y 137/1987, 148/1994, 149/1995, o de esta Sala -Sentencias de 4 de noviembre de 1993, 7 de junio de 1995, entre tantas otras-e ignorando lo que, por el contrario, tan contundentemente se ha estimado probado, que por demás es sustancialmente coincidente en ambas instancias. Este modo de proceder, como tantas veces ha señalado la jurisprudencia, que consiste en partir de hechos distintos a los proclamados por la Sala a quo, acreditados y probados en la instancia, sin haberlos previamente desvirtuado por el cauce procesal adecuado (Sentencias de 12 de junio de 2002, 28 de octubre y 23 de noviembre de 2004, 16 de marzo, 8 de abril, 9 y 12 de mayo de 2005, entre tantas otras) conduce, sin más, a la desestimación.

Pero hay más. La Sala de instancia tiene por acreditada la insolvencia de la sociedad deudora, administrada por los codemandados, y tiene también por cierto que fue despatrimonializada a través de un acto de transmisión de activos en pago de deudas no vencidas ni exigibles. Acto que se llevó a efecto mediante un acuerdo de la Junta General en la que participaron los administradores, quienes no se opusieron ni evitaron su eficacia, esto es, no hicieron lo conveniente para evitar el daño (artículo 133.2 LSA, texto entonces vigente, ahora 133.3), además de que el hecho de la adopción del acuerdo por la Junta no les exonera (133.3 LSA texto vigente en el momento de los hechos, hoy 133.4). Se produce de este modo un concurso de acciones, pues los hechos, tal y como están descritos por la Sala, y no han sido combatidos eficazmente en casación, pueden ser subsumidos tanto en la acción individual de responsabilidad, pues la insolvencia de la sociedad de este modo provocada causó una lesión directa (Sentencias de 11 de octubre de 1991, 10 de diciembre de 1996, 11 de noviembre de 1997, 17 de diciembre de 2003, 20 de febrero de 2004), y fue provocada por "actos de los administradores", aun cuando fuere en sentido lato, comprendiendo la acción y la omisión (artículo 135 LSA) y, al mismo tiempo, provocó la necesidad de una disolución y liquidación ordenadas de la sociedad, de acuerdo con el artículo $260,3^{\circ}$ y $4 .^{\circ} \mathrm{LSA}$ (texto vigente entonces) y con las consecuencias señaladas en el artículo 262. 5 LSA (Sentencias de 4 y 24 de abril de 2006, entre otras). La acción para reclamar la responsabilidad solidaria de los administradores por esta causa es, a juicio de esta Sala, después de la Sentencia de 24 de abril de 2006, una acción de responsabilidad, pero su especial carácter la dota de singularidad indudable en cuanto a la laxitud de la relación de causalidad entre la actuación de los administradores y el daño ocasionado, y en cuanto al régimen, pues aquí, entre otros extremos, es indudable que no estamos ante un supuesto de aplicación del artículo 1968.2 CC, sino del artículo 949 CCom». 
H. Sobre ACCiÓN SOCIAL DE RESPONSABILIDAD, EX ART. 133 L.S.A.

I) ${ }^{63}$ El interés de esta sentencia que reproducimos a continuación es doble: primero, se trata de uno de los escasos supuestos de acción de responsabilidad social (no individual) de que conoce el Tribunal Supremo; segundo, se refiere a un supuesto de autocartera, compraventas cruzadas y venta simulada de acciones.

«FUNDAMENTOS DE DERECHO.

PRIMERO.- El objeto del proceso versa sobre acción de responsabilidad social por conducta ilegal y comportamiento negligente de los administradores de una sociedad anónima por haber diseñado y materializado una política de autocartera ilegal y realizado diversas compraventas cruzadas y una venta simulada de acciones a otra entidad para el aparcamiento temporal de los títulos y ocultación de la autocartera, todo ello con un grave daño económico para la sociedad anónima; a cuya acción se acumulan otras de responsabilidad civil de los apoderados de la sociedad, invalidez de compraventa por autocontratación, y de restitución ("condictiones de prestación") por el cobro de lo indebido y por enriquecimiento injusto.

Por la entidad mercantil "ADMINISTRACIÓN FINANCIERA E INMOBILIARIA, S.A.” (en acrónimo AFISA) se dedujo demanda de juicio declarativo ordinario de mayor cuantía, en la que solicita:

1. . - Se declaren nulas por autocontratación las ventas de 175.213 acciones de "AFISA" realizadas por "URBANIZADORA SOMOSAGUAS, S.A." los días 18, 19 y 20 de julio de 1990, a favor de la propia "AFISA", condenando a "URANIZADORA SOMOSAGUAS, S.A." a devolver a "ADMINISTRACIÓN FINANCIERA E INMOBILIARIA, S.A.” (AFISA) el precio recibido de 805.979 .800 pesetas. La nulidad de las compraventas conllevará la anulación de la amortización de las acciones vendidas por "URBANIZADORA SOMOSAGUAS, S.A.", ordenando la corrección de la inscripción 65. " de la hoja de "AFISA" en el Registro Mercantil, volviendo a ser dueña "URBANIZADORA SOMOSAGUAS, S.A." de las referidas acciones.

$2 .^{\circ} .-$ Subsidiariamente con respecto al punto $1 .^{\circ}$, se condene a "URBANIZADORA SOMOSAGUAS, S.A." a pagar a "ADMINISTRACIÓN FINANCIERA E INMOBILIARIA, S.A." (AFISA) la cantidad de 91.565.050 pesetas, como enriquecimiento injusto obtenido por "URBANIZADORA SOMOSAGUAS, S.A." durante el período de octubre de 1989 a Agosto de 1990 en que se desarrollo la política de autocartera a través de “SANTO DOMINGO 5, S.A.” y "AFISA", a las que se les causó un correla-

${ }^{63}$ STS de 17 de julio de 2009, Recurso 727/2005 (ponente CORBAL FERNÁNDEZ). Los casos de acción social de responsabilidad en los que ha entendido el TS son contadísimos. Otro supuesto, STS de 14 de marzo de 2005, Recurso 3920/1998 (ponente FERRÁNDIZ GABRIEL), de acción de responsabilidad social promovida por un socio. 
tivo daño por importe muy superior al enriquecimiento obtenido por "URBANIZADORA SOMOSAGUAS, S.A.".

3. .- Se declare la responsabilidad como Consejeros de DON Casiano, DON Federico y DON José Augusto y como Apoderado mandatario de Don Adrián por la dirección, control y ejecución de la política de autocartera desarrollada a través de "SANTO DOMINGO 5, S.A." y de la propia "AFISA" desde octubre de 1989 a agosto de 1990, y de los mencionados Consejeros y los Apoderados mandatarios DON Rafael, DON Justo, DOÑA Isabel por la negociación, decisión y ejecución del contrato de compraventa de las acciones de "SANTO DOMINGO 5, S.A." a favor de "CASTELLANA DE INVERSIONES Y NEGOCIOS, S.A." celebrado el 22 de junio de 1990, por el que se trataba de encubrir y aparcar toda la autocartera indirecta acumulada en "SANTO DOMINGO 5, S.A.", condenando a los mencionados Consejeros y Apoderados a indemnizar solidariamente a "ADMINISTRACIÓN FINANCIERA E INMOBILIARIA, S.A.” (AFISA) los siguientes daños producidos:

a) La cantidad de 3.135.743.545 pesetas de inversión neta en autocartera a través de "SANTO DOMINGO 5, S.A." y de la propia AFISA desde octubre de 1989 a agosto de 1990, que ha supuesto una pérdida definitiva al resultar amortizadas las acciones adquiridas.

b) La multa impuesta por Orden Ministerial del Ministro de Economía y Hacienda de 14 de marzo de 1994 por importe de 24.411.635 pesetas.

4. .- Se condene a "LUGARCE, S.A." a restituir a "ADMINISTRACIÓN FINANCIERA E INMOBILIARIA, S.A.” (AFISA) la cantidad de 399.840 .000 pesetas cobradas indebidamente mediante las facturas $2,3 \mathrm{y}$ 4/90, más sus intereses legales desde el día 4 de septiembre de 1990 hasta el completo pago de la devolución, incrementados en dos puntos desde que recaiga Sentencia firme en primera instancia.

5. .- - Se declare la responsabilidad de DON Adrián y DON Justo como mandatarios y apoderados que libraron el cheque con que se pagaron las facturas de "LUGARCE, S.A." por importe total de 399.840.000 pesetas, y de los demás Consejeros y Apoderados demandados en la medida en que ordenaran o autorizaran dicho pago, condenándoles, solidariamente entre sí y con "LUGARCE, S.A.", a indemnizar a "ADMINISTRACIÓN FINANCIERA E INMOBILIARIA, S.A.” (AFISA) del importe de 399.840.000 pesetas.

6. .- En todos los casos, se condene a satisfacer el interés legal de las cantidades a que se refiere cada condena, desde la fecha de la interposición de la presente demanda, salvo en el caso del punto $4 .^{\circ}$ en que se devengan desde el 4 de septiembre de 1990. E incrementados en dos puntos desde que recaiga Sentencia en primera instancia.

La Sentencia dictada por el Juzgado de $1 .^{\mathrm{a}}$ Instancia núm. 44 de Madrid el día 27 de diciembre de 2003 en los autos de juicio de mayor cuantía núm. 762 de 1994, rechazó la excepción de litisconsorcio pasivo necesario, y desestimó la demanda de AFISA, absolviendo a los demandados. La Sen- 
tencia dictada por la Sección 19. a de la Audiencia Provincial de Madrid el 27 de enero de 2005 en el Rollo núm. 656 de 2004, desestimó el recurso de apelación de AFISA, y confirmó la resolución recurrida.

Por la representación procesal de "ADMINISTRACIÓN FINANCIERA E INMOBILIARIA, S.A.” (AFISA) se interpuso recurso de casación (...).

El segundo aspecto del primer submotivo se refiere a si hay base para sentar la atribución de una conducta ilegal o negligente en el diseño, aprobación y materialización de la política de autocartera. En el motivo, y a lo largo de un gran número de páginas, se efectúa un importante, y plausible, esfuerzo intelectual y material para crear una versión que fundamente la atribución de una conducta ilícita a los codemandados. Sin embargo, la propia parte recurrente es consciente de la falta de sustento de su planteamiento. Ello es así, no solo ya por la reiteración con que incurre en el vicio casacional de hacer supuesto de la cuestión (por cierto, tanto por las apreciaciones fácticas ex novo como por las que contradicen las de los juzgadores que conocieron en primera instancia), sino, además, porque: a) Alega repetidamente la falta de motivación, sin advertir que sin ella no es posible la impugnación, y que el vicio (hipotético) tiene carácter procesal, y procedía denunciarlo mediante el recurso extraordinario por infracción procesal (arts. 218.2 y 469.1.2. ${ }^{\circ}$ LEC). b) Solicita la "integración del factum" que es mecanismo excepcional solo utilizable para tomar en cuenta hechos complementarios, y que no contradigan la valoración de la prueba efectuada en la resolución recurrida. Y, c) ataca la apreciación de la sentencia impugnada porque no considera vinculante para la jurisdicción civil las conclusiones de unas resoluciones administrativas y una sentencia de lo Contencioso-Administrativo de este Tribunal. Se alega que "causaría gran perplejidad, y dañaría la seguridad jurídica, que la jurisdicción no asumiera en su integridad la misma declaración de hechos probados, basada en la investigación objetiva de Instructores especializados designados por la Comisión Nacional del Mercado de Valores", pero tal argumentación no tiene en cuenta dos reparos: que el juzgador civil ha de fijar los hechos de conformidad con los elementos de prueba obrantes en su propio proceso, pudiendo separarse motivadamente de las apreciaciones fácticas realizadas por resoluciones de Tribunales de otro orden jurisdiccional, y que en todo caso la polémica suscitada no es susceptible de ser examinada en el ámbito del recurso de casación, de lo que va a resultar la inconsistencia de las consideraciones que desarrolla el motivo al basarse en apreciaciones desechadas por el Juzgador a quo. En definitiva, como la parte recurrente sienta sus propias premisas - presupuestos- y de ellos extrae sus propias conclusiones, el problema es que al divergir, o no estar reconocidas, las primeras por la sentencia impugnada, se incide en petición de principio haciendo imposible el juicio propio de la casación; por lo que el primer submotivo decae. 
El segundo submotivo se refiere a que, asimismo, la sentencia recurrida vulnera el régimen de responsabilidad solidaria de todos los miembros del órgano de administración previsto en el art. 133.2 LSA al aplicar indebidamente la causa de exoneración por oposición expresa al acto lesivo. La Sentencia recurrida, razona al respecto que "la propia recurrente reconoce la denuncia de los demandados de la política de autocartera pero argumenta que tal denuncia no era real y eficaz y venía a encubrir una actuación encaminada precisamente en sentido contrario, extremo este que debe ser rechazado careciendo de sentido la oposición formal y pública a una determinada línea de actuación, y luego sin embargo la ejecución por su cuenta de la misma”. Para la parte recurrente no basta la oposición formal si no va acompañada de una actuación coherente con dicha oposición, exigiéndose, según la jurisprudencia, una actuación positiva para evitar el daño.

El submotivo se desestima porque su planteamiento fáctico no es congruente con la relación de hechos de la Sentencia de 1. ${ }^{\mathrm{a}}$ Instancia (asumida implícitamente en la recurrida), y porque, a los efectos del art. 133.2 (apartado 3 desde Ley 26/2003) -que exonera de responsabilidad a los miembros del órgano de administración que realizó el acto o adoptó el acuerdo lesivo que prueben que, no habiendo intervenido en su adopción y ejecución, desconocían su existencia o, conociéndola, hicieron todo lo conveniente para evitar el daño o, al menos, se opusieron expresamente a aquel-, hay que estimar como actitud diligente,suficiente para fundamentar la exoneración, la denuncia de la política de autocartera y de su ilegalidad una vez entrada en vigor la LSA de 1989, lo que dio lugar al nombramiento de una comisión para afrontar el problema de la que no formaron parte los Consejeros minoritarios, y la actividad de gestión desplegada, a causa de la inactividad de dicha comisión, en orden a conseguir la transmisión de la autocartera ilegal mediante contrato de venta de las acciones a la entidad Castellana de Inversiones, con lo cual quedaba resuelta la situación de las acciones en autocartera, según declara probado la resolución de primera instancia.

Por todo ello, decae también el submotivo segundo, cuya desestimación opera como refuerzo de la exclusión de responsabilidad para los Consejeros codemandados desde la perspectiva de la solidaridad prevista para todos los miembros del órgano de administración en el art. 133 de la $L S A »$.

II $)^{64}$ Acción social de responsabilidad ejercitada por el socio. Sobre la incompatibilidad de ejercicio conjunto (por la sociedad y por el socio) de la acción social de responsabilidad.

«PRIMERO.- El litigio causante de este recurso de casación fue promovido por una sociedad anónima y tres hermanas accionistas de la misma con-

${ }^{64}$ STS de 21 de febrero de 2007, Recurso 903/2000 (ponente MARÍn CASTÁN). 
tra otro hermano, también accionista, contra su madre, igualmente accionista, y contra quien había sido administrador único de la referida sociedad y albacea contador-partidor de la herencia del padre de las demandantes, fallecido cinco años y medio antes. En la demanda se ejercitaban dos acciones: una contra este antiguo administrador único de la sociedad, fundada en el art. 134 LSA de 1989, aunque también se citaban como aplicables los arts. 79 y 80 de la LSA de 1951, orientada a declarar responsable a dicho demandado frente a la sociedad actora "y frente a sus accionistas" de los daños causados en el desempeño de su cargo, pidiendo su condena, entre otros extremos, a reponer a la sociedad las cantidades indebidamente detraídas de sus cuentas, "en beneficio propio o de otras entidades", y a indemnizar los daños y perjuicios causados por haber cedido a otra sociedad la explotación de una cantera de arcilla; y la otra acción contra los tres demandados, por haber actuado de mala fe y con ánimo defraudatorio al constituir esa otra sociedad excluyendo a las tres hermanas demandantes y cediendo a la nueva sociedad la explotación de la cantera de arcilla que pertenecía a la sociedad codemandante, acción esta última fundada en los arts. 433, 1902, 1101, 1102, 1106, 1107 y 1108 CC y en cuya virtud se pedía una indemnización de daños y perjuicios en la cuantía que se fijara en ejecución de sentencia sobre las bases señaladas en la propia demanda, a cuyo pago habrían de ser condenados solidariamente los tres demandados.

Estos contestaron a la demanda por separado aunque en términos prácticamente idénticos, pero posteriormente, antes de la comparecencia del juicio de menor cuantía, la demandada madre de las tres codemandantes presentó escrito reconociendo como ciertos los hechos de la demanda, manifestando haber conocido tardíamente los "manejos" del albacea de la herencia de su difunto esposo y allanándose sin reserva alguna a las peticiones de dicha demanda (...).

Pues bien, este motivo, al que la parte recurrida no opone el defecto de plantear una cuestión nueva, debe ser estimado porque ciertamente el párrafo tercero del art. 80 LSA de 1951, como ahora el apdo. 4 del art. 134 LSA de 1989, no autorizaba un ejercicio conjunto de la acción social de responsabilidad por la sociedad y por sus accionistas, sino que facultaba a estos para ejercitarla únicamente cuando la sociedad no lo hiciese dentro del plazo de tres meses a contar desde el acuerdo o cuando el acuerdo hubiera sido contrario a la exigencia de responsabilidad.

De ahí que la sentencia recurrida haya incurrido en la infracción normativa denunciada, que se advierte más claramente todavía en los pronunciamientos condenatorios del hoy recurrente, a reponer determinadas cantidades, pues este reintegro se acuerda, lógicamente, a favor solo de la sociedad actora». 


\section{DifERENCIA ENTRE ACCIONES EX ART. 135 y 262.5 L.S.A.}

I) ${ }^{65}$ «SEGUNDO: La parte recurrente articula inicialmente en dos motivos su recurso pero luego los enuncia conjuntamente, con apoyo procesal en el artículo 1.692.4. ${ }^{\circ}$ de la Ley de Enjuiciamiento Civil, por "aplicación indebida o inaplicación de los artículos 133 y 135 en relación con los artículos 260 y 262, 1.902 todos (sic) del texto refundido de la Ley de Sociedades Anónimas, aprobado por Real Decreto Legislativo 1.564/1989 que regulan la acción individual de responsabilidad solidaria de los administradores y doctrina jurisprudencial aplicable para resolver las cuestiones objeto de debate", para terminar a su vez desarrollándolos como submotivos.

El primer submotivo se centra en la acción con sede en los artículos 133 y 135 de la Ley de Sociedades Anónimas, alegando que se dan los requisitos para la existencia de la acción individual de responsabilidad, ya que, primeramente, existió una acción u omisión culposa de los administradores, que no utilizaron los mecanismos legales previstos para regularizar la situación -quiebra, disolución, aumento de capital, liquidación en forma del patrimonio social-, sino que se han limitado a hacer desaparecer la sociedad; en segundo lugar, se ha producido una lesión directa a los intereses del demandante por el impago de la deuda; y, por último, entre una y otra existe un nexo causal consistente en que, el Administrador responsable de la gestión, a sabiendas de la existencia de una deuda, no adoptó las medidas legales y, pese a la total descapitalización de la sociedad y su desaparición de hecho, no liquidó el patrimonio -lo que integraría el presupuesto de la causa de disolución que contemplan los números 4 y 5 del artículo 260 de la Ley de Sociedades Anónimas-.

Este primer submotivo debe ser desestimado.

Ha de comentarse por significar que, si bien inicialmente se aducen como infringidos los artículos 133 y 135 de la Ley de Sociedades Anónimas -en concreto relativos a la acción individual de responsabilidad posteriormente va derivando progresivamente hacia el intento de justificación de la especial acción de responsabilidad del artículo 262,5. ${ }^{\circ}$ de la misma Ley de Sociedades Anónimas. Lo cierto que en su demanda fundó todos los incumplimientos en el artículo 135 de la Ley de Sociedades Anónimas, siendo que la acción que prevé el artículo 262.5 distinta en sus presupuestos, y en su regulación legal: la primera tiene naturaleza extracontractual y requiere que concurran los requisitos propios -acción u omisión culposa, daño y prueba de la relación de causalidad-; lo que no sucede con la acción del 262, respecto de la cual, esta Sala ha destacado su carácter abstracto o formal -Sentencia de 26 de junio de 2006-, y, con mayor propiedad, su naturaleza obje-

${ }^{65}$ STS de 8 de marzo de 2007, Recurso 5041/2000 (ponente SiERRA GIL DE CUESTA). 
tiva o cuasi objetiva -Sentencias de 25 de abril de 2002, 14 de noviembre de 2002, 6 y 28 de abril de 2006 (esta última de Pleno), y 26 de mayo de 2006, entre otras-, que se resume en que su declaración no exige la concurrencia de un reproche culpabilístico que hubiera que añadir a la constatación de que no ha habido promoción de la liquidación mediante convocatoria de la Junta o solicitud judicial, en su caso -y ahora también la solicitud de la declaración de concurso, cuando concurra su presupuesto objetivo-, esto es, una negligencia distinta de la prevista en el propio precepto -Sentencias de $20 \mathrm{y}$ 23 de febrero de 2004 y de 28 de abril de 2006-, del mismo modo que no requiere una estricta relación de causalidad entre el daño y el comportamiento concreto de administrador, o, en otros términos, no exige más que el enlace causal preestablecido en la propia norma -Sentencia de 28 de abril de 2006-.

Sentado lo anterior, y desde el punto de vista de la acción individual de responsabilidad -lo relativo a la acción de responsabilidad del artículo 262.5 de la Ley de Sociedades Anónimas se verá en el submotivo siguiente-, se ha de partir de los hechos declarados probados por la Audiencia Provincial, que deben permanecer incólumes en casación, salvo que previamente se logre su sustitución por el cauce de error de derecho en la valoración de la prueba, que exige, su planteamiento a través del correspondiente motivo de casación, con la cita, como infringida de la norma que contenga la regla de prueba que se considere vulnerada, y la subsiguiente exposición de la nueva resultancia probatoria según el recurrente, lo que en este caso no se ha hecho. La sentencia de la Audiencia Provincial declara que no resulta acreditado que sea culposa o negligente la falta de convocatoria de la Junta, para autorizar al administrador la venta o dación en pago de los chalets construidos, ya que las operaciones realizadas corresponden al tráfico comercial de la sociedad y estar entre las facultades del administrador; ni que tampoco lo sea la propia venta o dación en pago de los inmuebles, ya que la misma tuvo por objeto la cancelación de deudas que tenían el carácter de preferentes sobre el crédito de la demandante, lo que fue beneficioso para la sociedad; y, por último, en cuanto a la falta de liquidación de la sociedad, falta la relación causal entre tal omisión y el daño alegado, por la imposibilidad de cobrar los créditos reclamados en el procedimiento -como en un supuesto semejante ha señalado la Sentencia de esta misma Sala de 9 de octubre de 2006 (rec. 3482/99)-.

TERCERO: El segundo submotivo, tiene por objeto la acción de responsabilidad solidaria por las obligaciones sociales, regulada en el artículo 262 en relación con el artículo 260, ambos de la Ley de Sociedades Anónimas, señalando la recurrente que, de la prueba practicada en autos, se habría puesto de manifiesto una situación de cierre y de abandono de la propia sociedad, fijando en septiembre de 1993 la fecha del sobreseimiento de los pagos por la sociedad, entendiendo que la carga de la prueba de la causa o causas del cese debía corresponder al demandado. 
Este motivo debe sufrir la misma suerte desestimatoria de su antecesor.

De nuevo la parte recurrente mezcla cuestiones de hecho y de derecho, llamando la atención que el recurrente pretenda alegar como acción independiente la del artículo 262.5 de la Ley de Sociedades Anónimas, cuando en su demanda no fue citada y simplemente se adujo la falta de convocatoria de la Junta, como presupuesto para fundamentar la negligencia de los administradores, al hilo de la acción del artículo 135 de la Ley de Sociedades Anónimas, por lo que su alegación posterior en el escrito de conclusiones, y por tanto fuera de los escritos rectores, es extemporáneo y va contra los principios procesales de igualdad de armas, y desde luego, provoca una situación procesal anómala. Es más, la reciente Sentencia de 9 de octubre de 2006 con cita de la de la de 26 de mayo de 2006 señala como "No es procedente examinar la posible infracción del artículo 262.5 LSA (en relación con el artículo 69 de la Ley de sociedades de responsabilidad limitada), cuando la acción ejercitada fue la acción individual de responsabilidad y no la acción de responsabilidad solidaria por incumplimiento de las obligaciones de los administradores de promover la disolución de la sociedad, pues ello determinó que en el proceso no se discutieron los presupuestos del ejercicio de tal acción, muy particularmente el transcurso del plazo exigido por la ley desde el momento de la disminución del patrimonio social o la situación de crisis para que pueda exigirse responsabilidad a los administradores por este concepto. En consecuencia, continúa diciendo la citada sentencia, la estimación de esta acción comportaría una desviación respecto de la causa petendi [causa de pedir] que fundamentó la pretensión inicial con infracción de los principios de rogación y contradicción. En efecto, la pretensión debe identificarse en función de los hechos sustanciales que constituyen su causa petendi aunque no se cite el precepto en que se apoyan las consecuencias jurídicas que componen el petitum [lo que se pide], salvo cuando aquellos hechos son ambiguos o no son expresivos por sí mismos de la acción ejercitada, caso en el que será exigible que se identifique jurídicamente la pretensión con la cita, si es preciso, de los preceptos legales en que se apoya".

Consecuentemente, se hace innecesario el análisis de la alegación, hecha incidentalmente en relación con el artículo 1.214 del Código Civil».

II) ${ }^{66}$ Diferencia entre la responsabilidad del administrador y la responsabilidad de la sociedad. Doctrina del levantamiento del velo.

«FUNDAMENTOS DE DERECHO.

PRIMERO.- El objeto del proceso versa sobre la resolución unilateral de un contrato de licencia de utilización de marcas, existente entre dos sociedades, y sobre la responsabilidad de los administradores de la sociedad concedente, la cual resolvió de modo unilateral e injustificado el vínculo contrac-

${ }^{66}$ STS de 30 de mayo de 2008, Recurso 1040/2001 (ponente CORBAL FERNÁNDEZ). 
tual. El recurso de casación se circunscribe al examen de la responsabilidad de los administradores sociales, que se plantea en una doble perspectiva: responsabilidad individual ex art. 135 LSA y conducta fraudulenta con base en la doctrina jurisprudencial del "levantamiento del velo". Por la entidad mercantil "GOLD VISION, S.L." se dedujo demanda frente a la compañía "Diseño y Difusión de Moda, S.A.", antes denominada "Enrique Loewe Knappe, S.A.", y frente a los, en su día, miembros del Consejo de Administración de "Diseño y Difusión de Moda, S.A.", Dn. Jon, Dn. Marcos, Dn. Pedro Jesús y Dña. Camila, en ejercicio de las acciones de daños y perjuicios sufridos por la actora a causa de la actuación fraudulenta llevada a acabo por "Diseño y Difusión de Moda, S.A." (antes "Enrique Loewe Knappe, S.A.") y acción individual de responsabilidad frente a los, en su día, administradores de "Enrique Loewe Knappe, S.A." (hoy "Diseño y Difusión de Moda, S.A.") en reclamación de los daños y perjuicios por ellos ocasionados directamente a la actora. En el suplico se solicita: a) Se condene a "DISEÑO Y DIFUSIÓN DE MODA, S.A." a pagar a "GOLD VISION S.L." la indemnización que se determine por el juzgador por los daños y perjuicios derivados a "Gold Visión, S.L." por la fraudulenta resolución del Contrato de Licencia de Utilización de Marca suscrito el 30 de julio de 1993; y, b) se condene, solidariamente entre sí y junto con "Diseño y Difusión de Moda, S.A." (antes "Enrique Loewe Knappe, S.A."), esto es, a Dn. Jon, Dn. Marcos, Dña. Camila y Dn. Pedro Jesús, a pagar a "Gold Visión S.L." la indemnización que determine el juzgador por los daños y perjuicios causados a la actora por la fraudulenta resolución del Contrato de Licencia de Utilización de Marca suscrito el 30 de julio de 1993.

Los antecedentes en que se apoyan las pretensiones de la actora se resumen en los siguientes puntos: a) El 30 de diciembre de 1994 la compañía demandante se subrogó en el contrato de licencia de utilización de las marcas "ELK" y "Enrique Loewe Knappe" (para monturas ópticas, gafas de sol y fundas de gafas), como concesionaria única mundial, que habían celebrado el 30 de julio de 1993 la entidad "LOOK OCCHIALI, S.L." y "ENRIQUE LOEWE KNAPPE, S.A." (actualmente "Diseño y Difusión de Moda, S.A."); b) el 5 de febrero de 1996 la entidad concedente "Enrique Loewe Knappe, S.A." notificó notarialmente a "LOOK OCCHIALI, S.L." la resolución del contrato de licencia de utilización, lo que se comunica por el letrado de "Diseño y Difusión de Moda, S.A." a "Gold Vision, S.L." por telegrama de 3 de noviembre de 1997, en el sentido de que quedaba también resuelto para ella; c) a juicio de la actora, la resolución es improcedente por ser absolutamente falsas las causas o motivos de incumplimiento alegados en la carta de resolución, y, además, por no haberse notificado a la verdadera concesionaria, y no haber tenido lugar el requerimiento previo de rectificación de proceder previsto en el contrato; d) el verdadero motivo de la resolución fue el acuerdo transaccional celebrado entre "Enrique Loewe Knappe, S.A.” y “LOEWE S.A.” el 1 de febrero de 1996 [en realidad fue el 
27 de enero], y por el que aquella sociedad, a cambio de quedar liberada de pagar a esta última sociedad mercantil española una indemnización por la utilización durante los últimos once años de las marcas "ELK" y "ENRIQUE LOEWE KNAPPE", cesaba inmediatamente en la utilización de las marcas (cese en el uso de todos los signos distintivos y de la misma imagen personal de Dn. Jon). Por consiguiente -alega la demandante-, las razones de la resolución no fueron el incumplimiento de la licenciataria, sino la transacción expresada, aparte de que los tribunales españoles [de cuya resolución surge la celebración de la transacción expresada] no autorizaron a "Enrique Loewe Knappe, S.A." a utilizar el nombre de "Loewe" en España, pero nada impedía utilizarlo en el extranjero; e) la fraudulenta resolución ha supuesto para la actora cuantiosos daños y perjuicios; f) los auténticos responsables de que se resolviese el Contrato de Licencia de Utilización de Marca fueron los administradores de "Enrique Loewe Knappe, S.A.", dado que fueron los que tomaron la decisión de resolver el Contrato aun a pesar del daño y perjuicio enorme que se le derivaba a la licenciataria; g) cuando se comunica la resolución del contrato el 5 de febrero de 1996, los administradores de "ENRIQUE LOEWE, S.A." eran los demandados; y, h) se alega la existencia por parte de los mismos de mala fe, simulación y fraude, y además la responsabilidad, de acuerdo con la "teoría del levantamiento del velo", por aquellas actuaciones realizadas por la sociedad que hubiesen perjudicado a terceros, ya que la Sociedad no es más que un mero instrumento por el cual estos pueden llevar a cabo sus actuaciones personales. La Sentencia dictada por el Juzgado de 1. ${ }^{a}$ Instancia número 21 de Barcelona el 28 de septiembre de 1998, en los autos de juicio de menor cuantía núm. 1103 de 1997, estima la demanda interpuesta por "GOLD VISION S.L.", contra "DISEÑO Y DIFUSIÓN DE MODA, S.A.”, Dn. Jon, Dn. Marcos, Dn. Pedro Jesús y Dña. Camila, y condena a los demandados a abonar solidariamente a la actora la indemnización de daños y perjuicios que se fije en ejecución de sentencia confo me a las bases contenidas en esta resolución (...).

La Sentencia de la Audiencia señala que "en contra de lo que sostiene la sentencia apelada no cabe deducir de forma inexorable un comportamiento empresarial contrario a lo que dispone el artículo 127 de la Ley de Sociedades Anónimas, dadas las alternativas ante las que se adoptó la decisión”. Y después de discurrir acerca de que "tanto en el supuesto de que la decisión fuese acertada para la sociedad..., como si fuese errónea..., es lo cierto que en el caso de autos no se trata de la exigencia de la responsabilidad del administrador frente a la sociedad por actos realizados sin la diligencia de un ordenado empresario o como representante desleal, porque de lo que se trata es de analizar si las consecuencias de la actuación de los demandados dañosas para la actora, imputables a la sociedad en tanto en cuantos actuaron como órgano de esta, deben atribuirse, además de a la sociedad que actuó valiéndose instrumentalmente de ellos, a los administradores", expresa la 
ratio decidendi en el fundamento séptimo diciendo que constituyen premisas de la decisión adoptada las siguientes:

“1) Como precisa la sentencia del Tribunal Supremo de 15 de abril de 2000, siguiendo la línea trazada por la de 2 de julio de 1998, es necesario diferenciar entre la sociedad y sus órganos de administración. Quien se vincula por el contrato no son los administradores, sino la sociedad administrada, sin que, como regla, puedan imputarse a los administradores los incumplimientos de la sociedad, bajo el riesgo, en otro caso, de desconocer alternativamente: a) la personalidad jurídica propia de las sociedades que, en el caso de las anónimas atribuye el artículo 7 de la Ley de Sociedades Anónimas a las inscritas; o b) el principio de que los contratos solo producen efecto entre las partes que los otorgan y sus herederos, que proclama el artículo 1257 del Código Civil. 2) Como hemos apuntado, en el presente caso se evidencia que una actuación beneficiosa para la sociedad administrada, adecuada a la diligencia del ordenado empresario y del leal representante, puede resultar perjudicial para el tercero, es por lo que el artículo 135 de la Ley de Sociedades Anónimas, al enunciar que los administradores responderán de los actos que lesionen directamente los intereses de los terceros, precisa que lo es 'no obstante lo dispuesto en los artículos precedentes' que tienen por finalidad regular la actuación del administrador en el ámbito societario no frente a terceros -el administrador debe ser leal a la sociedad, a la que ha de administrar como ordenado empresario, no a los terceros con quienes ningún vínculo mantiene-; y 3) para que los administradores deban responder no es suficiente que su actuación, correcta desde la perspectiva interna, devenga a la postre dañosa para terceros. Es necesario, además, la existencia de una singular relación causal requerida por la norma y reiteradamente exigida por la Jurisprudencia: que la relación entre el daño y la actuación de los administradores sea 'directa'. Pues bien, no es este el caso de autos en el que el daño deriva de forma 'directa' de la resolución injustificada y unilateral del contrato 'por la sociedad' concedente. No por sus administradores que no fueron parte en él".

La argumentación expuesta es razonable y coherente y no ha sido desvirtuada por la parte recurrente.

En su ratificación, y reiteración, solo cabe decir aquí que, vistas las circunstancias concurrentes en el caso, la conducta observada por la entidad "Jon, S.A." en relación con la resolución del contrato que le unía a "Gold Vision, S.L." fue totalmente injustificada, aunque, por otro lado, no resulta verosímil que esta entidad no conociese la situación litigiosa de las marcas cuando formalizó el contrato de licencia. Pero sí resulta incuestionable dicha actuación antijurídica, que ya fue objeto de pronunciamiento condenatorio, de ello no cabe derivar, dadas dichas circunstancias, una responsabilidad individual, solidaria, de los administradores sociales ex arts. 127, 133 y 135 LSA. De aceptarse tal expansión de la responsabilidad, los administradores pasarían prácticamente a ser responsables -garantes- de todas las actuacio- 
nes de la sociedad que, por unas u otras razones, resultaran ilícitas por su disconformidad con el ordenamiento jurídico y produjeran un perjuicio para otras personas. Y no es esto lo que establece la Ley.

En la actuación de los administradores sociales del caso no concurre una conducta fraudulenta o negligente en el ejercicio de su cargo que se conecte causalmente en relación directa, como exige el art. 135 LSA, con el perjuicio sufrido por la entidad actora. Este perjuicio se deriva de la actuación de la sociedad, sujeto de derecho con personalidad jurídica autónoma, que, ante la alternativa que se encontraba, optó por dar satisfacción económica a una empresa en detrimento de otra, y la actuación de los administradores, como órgano de la sociedad, precisada de personas físicas para su operatividad jurídica, no se individualiza respecto del ente social, sino que se integra plenamente en la organicidad de la sociedad, que no es susceptible de una valoración individual, con secuencia de responsabilidad, independiente de por quien actuaron como representantes necesarios.

En el mismo sentido expuesto se ha manifestado la Sentencia de 27 de julio de 2007.

TERCERO.- En el motivo segundo se alega la infracción de los arts. 6.4 y 7 del Código Civil, y 7 de la Ley de Sociedades Anónimas para sostener que la Sentencia de la Audiencia Provincial no ha aplicado la doctrina del levantamiento del velo (SSTS 28 de mayo de 1984, 20 de junio de 1991 y 16 de marzo de 1992).

El motivo se rechaza por su total falta de fundamento.

Para una correcta aplicación de la técnica del levantamiento del velo es preciso que se acredite la concurrencia de dos premisas: a) la primera es que exista un mal uso (abuso) de la personalidad de la sociedad; b) la segunda consiste en que se haya producido un daño o un perjuicio para un tercero. Como consecuencia de ello, la persona o personas que "instrumentan" la sociedad causante del daño deben responder, sin que se puedan amparar en la responsabilidad limitada de la misma. No es suficiente la existencia de una conducta antijurídica de la sociedad, sino que además es preciso que la misma se utilice abusivamente para causar el perjuicio al tercero.

En el caso, no hay la mínima base fáctica para configurar el planteamiento del recurso. El levantamiento del velo no es una hipótesis, sino que requiere el pleno acreditamento de las premisas que fundamentan la aplicación de tal técnica jurídica, y aquí falta la instrumentación de la personalidad autónoma de la sociedad para, como consecuencia de la limitación de la responsabilidad jurídica de esta, producir un perjuicio a tercero.

Finalmente, y en lo que se refiere a las Sentencias señaladas en el enunciado, no hay similitud de los casos en ellas resueltas con el que es objeto de enjuiciamiento.

La de 28 de mayo de 1984 se refiere a una reclamación de indemnización de daños contra una empresa municipal que tenía contratado con un Ayuntamiento el servicio de abastecimiento de agua. Era un ente filial puro 
y simple del Ayuntamiento, siendo este un órgano de la sociedad y el Alcalde el Presidente del Consejo. Se estimó eficaz la interrupción de la prescripción extintiva entendida con el Ayuntamiento.

En la Sentencia de 20 de junio de 1991 se hace referencia a un supuesto muy complejo en que se apreció un claro y burdo montaje urdido entre la actora y su marido para conseguir el ilícito beneficio de un cobro al que no podía tener el más mínimo derecho por tratarse de una pura invención o maniobra fraudulenta que afloraba de las interrelaciones entre los expresados cónyuges y dos sociedades. La aplicación de la técnica del levantamiento del velo respondió a la oportunidad de sancionar el fraude impidiendo se alcanzase el efecto defraudatorio de pagar dos veces a quienes venían ligados por un solo interés, evitándose el enriquecimiento injusto que se pretendía. Y en la Sentencia de 16 de marzo de 1992 consta como probado que la sociedad, constituida por unos hermanos que habían heredado un negocio de su padre, fue creada como mero instrumento o testaferro, para, bajo la pantalla o velo de su personalidad, mantener las relaciones jurídicas con los terceros.

Por todo ello, el motivo decae».

$\mathbf{J}^{67}$. SOBRE LA POSIBILIDAD DE APLICAR O NO AL APODERADO EL RÉGIMEN DE RESPONSABILIDAD DE LOS ADMINISTRADORES Y CONDICIONES DE LA ACCIÓN DE RESPONSABILIDAD CONTRA LOS ADMINISTRADORES.

«Con todo, el punto nuclear de la cuestión que suscita se encuentra en la posibilidad de aplicar el régimen de responsabilidad de los administradores a un apoderado, lo que nada tiene que ver con la posibilidad de que el empresario pueda constituir apoderados o mandatarios generales o especiales (artículo $281 \mathrm{CCom}$.) ni con el efecto directo o representativo de la actuación del llamado "factor notorio" (artículo 286 CCom.), si bien en el tráfico puede presentarse bajo la veste de un apoderamiento la figura del "Administrador de hecho" (STS 30 de julio de 2001), pero en el caso los preceptos que se dicen infringidos no han podido serlo por una sentencia que no los ha aplicado, ni tenía por qué hacerlo, ya que no se plantea una cuestión que pueda ser comprendida en ellos. El tema, pues, se centra en la posibilidad de aplicar a un apoderado el régimen de responsabilidad prevista para los administradores en los artículos 133 y siguientes de la Ley de Sociedades Anónimas, entre otros. El recurrente pone de relieve una y otra vez la amplitud de los poderes, con lo que parece estar indicando que se trata de un verdadero "Administrador de hecho", figura ahora expresamente recogida en el artículo 133.2 LSA, por efecto de la modificación operada por la Ley 26/2003, de 17 de julio, pero que ya se había apuntado doctrinal y jurisprudencialmente

${ }^{67}$ STS de 14 de marzo de 2008, Recurso 74/2001 (ponente MonTES PENADÉs). 
con anterioridad (SSTS 3 de marzo de 1977, 27 de octubre de 1997, 5 de abril de 1999, 9 de julio de 2000, 26 de mayo de 2003, Resolución de la Dirección General de Registros y del Notariado de 14 de enero de 1994, etc.). El recurrente lo sugiere, pero la apreciación carece de soporte en una estimación de hecho (SSTS 7 de junio de 1999, 30 de julio de 2001, 22 de marzo de 2004, etc.), que le correspondía hacer a la Sala de instancia, y que, no verificada por la Sala en ejercicio de su competencia, solo podría ser introducida en cuanto cupiera una revisión de los hechos probados por la vía del error de Derecho en la apreciación de la prueba o de la constatación de un error patente, lo que ni siquiera se ha intentado. Por el contrario, la Sala de apelación ha señalado que el apoderado no intervino en las operaciones que generaron la descapitalización de la sociedad y que, en cuanto apoderado, no le comprende la responsabilidad establecida para los administradores. (....) En resumen, pues, la responsabilidad de la recurrente, Administradora de EDIFOR, S.A. entre el 30 de enero de 1994 y el 29 de enero de 1997, se deriva del impago por EDIFOR, S.A. del precio convenido con la vendedora PROINCOSA por la compraventa de unos inmuebles, lo que habría generado la despatrimonialización de la vendedora, que adeudaba a los hoy actores ciertas cantidades a cuyo pago había sido condenada por sentencia firme.

La Sentencia recurrida aplica, en efecto, el artículo 135 de la Ley de Sociedades Anónimas, y rechaza la del artículo 1111 del Código civil (acción subrogatoria), pues entiende, correctamente en este punto, que los actores están actuando un interés propio, y no por subrogación en los derechos de PROINCOSA frente a EDIFOR, S.A.

En ningún caso se ha fundamentado la reclamación en la omisión de los deberes que el artículo 262, en relación con el 260, ambos LSA, imponen a los administradores, con la responsabilidad consiguiente en los términos establecidos en el artículo 262.5 LSA, aunque es cierto que en el caso el ejercicio de la acción ofrecía una dificultad añadida, ya que los actores son acreedores de PROINCOSA, y no de EDIFOR, S.A. y, en caso de ejercicio de esta acción, deberían haber actuado, como acreedores de EDIFOR, S.A., por vía de subrogación en el crédito de PROINCOSA (artículo 1111 CC) y, por tanto, para que esta pudiera cobrar su crédito, que constituiría un activo a disposición de todos sus acreedores.

El artículo 135 LSA regula la llamada acción individual de responsabilidad en la que cabe ver, a pesar de alguna duda suscitada por la redacción del precepto, un supuesto de acción de responsabilidad extracontractual sometida al régimen especial de los artículos 133 a 135 LSA (presunción de culpa con traslación de la carga de la prueba, restricción de los supuestos de exoneración, solidaridad y régimen especial de prescripción), pero, en definitiva, una especialidad del régimen general de responsabilidad extracontractual regido por los artículos 1902 y sigs. del Código civil.

Como ha dicho la Sentencia de 14 de marzo de 2007, la jurisprudencia ha venido exigiendo, para que nazca la responsabilidad de los administra- 
dores que se establece en los artículos 133.1 y 135 LSA que concurran los siguientes requisitos:

a) Que se haya producido un daño que ha de consistir en una lesión directa al patrimonio del socio o del tercero, por lo que no basta acreditar la mera insolvencia de la sociedad (STS 28 de abril de 2006), ni es bastante para determinar la existencia de responsabilidad el solo hecho del incumplimiento de una obligación social (SSTS 2 de julio de 1998, 20 de julio de 2001, 6 de marzo de 2003, etc.).

b) Que se hayan producido actos $\mathrm{u}$ omisiones negligentes por parte de los administradores (o actos contrarios a la Ley o a los Estatutos) en el ejercicio del cargo, por incumplimiento de los deberes establecidos en el artículo 127 LSA (o, en su caso, de los deberes de fidelidad y lealtad de los artículos 127 bis, 127 ter y 127 quáter).

c) Que exista relación de causalidad entre la conducta y el daño (STS 7 de marzo de 2006). La acción individual de responsabilidad, así entendida, no deriva de una relación contractual o extracontractual preexistente con la sociedad, sino del ejercicio ilícito o abusivo de su cargo por parte del Administrador, que ha generado una lesión directa en el patrimonio del tercero (o del socio). La doctrina y la jurisprudencia han puesto de relieve la dificultad de establecer el carácter directo de la lesión (SSTS 21 de mayo de 1985, 9 de julio de 1999, 26 de mayo, 5 de junio y 27 de octubre de 2006, etc.) y la doctrina de esta Sala ha sido rigurosa en la comprobación de los requisitos, antes señalados, referentes al daño, a la culpa y al nexo causal (SSTS 31 de julio de 1996, 20 de marzo de 1998, 9 de julio de 1999, 4 de enero, 16 de febrero y 28 de junio y 29 de diciembre de 2000,3 de mayo y 8 y 26 de octubre de 2007, etc.).

En el caso, son dudosos la identificación del daño, la relación de causalidad y, en el fondo, la imputación a los administradores de la sociedad que, habiendo comprado, no prueba que pagó el precio convenido. Se trata de una indemnización que reclaman los acreedores de una sociedad que vendió a otra unos bienes y que esta última no ha pagado. Los acreedores que reclaman la indemnización pretenden la imputación del daño que han sufrido a los administradores de la sociedad compradora.

El daño, ante todo, se encuentra en la imposibilidad de cobrar su crédito de una sociedad insolvente, que lo es, entre otras razones, pero no la única, por haber sido descapitalizada por sus propios administradores (condenados, aunque por otras razones se haya anulado esa condena) que no han ejercitado las acciones frente a la otra sociedad, compradora, que también ha sido condenada en primera instancia, condena que no puede ser revisada por ausencia de un recurso (estaba en rebeldía) y porque sus codemandados, solidariamente condenados, no han suscitado la cuestión en apelación. La sociedad adeuda, entre otros acreedores a la Tesorería General de la Seguridad Social, cantidades muy superiores al crédito cuya reclamación da pie a la petición de indemnización que es objeto de este conflicto. Se intenta esta- 
blecer una ecuación entre el importe del crédito cuya reclamación se ha frustrado por la insolvencia de la entidad deudora y la falta de pago del precio convenido por los bienes transmitidos, olvidando que el crédito por el precio hubiera sido, en todo caso, un activo de la sociedad vendedora, a disposición del pasivo exigible, no solo formado por ese crédito de los actores en este litigio, y por otra parte carente de un privilegio especial que determinara la preferencia de los actores.

La relación de causalidad entre el daño y la acción (u omisión) de los administradores de la sociedad compradora no presenta tampoco los caracteres de un enlace directo entre comportamiento y daño. Los administradores demandados (de la sociedad compradora) no efectúan el pago a la sociedad vendedora, y esta no ejerce las acciones pertinentes, lo que determina la responsabilidad contractual de la sociedad compradora y la responsabilidad de los administradores de la vendedora, pero para alcanzar a los administradores de la compradora haría falta establecer con nitidez la participación o colaboración en el fraude, lo que no se realiza en la sentencia recurrida, pues en ella (FJ Tercero) se dice que la administradora de única (de la sociedad compradora) "estaba autorizada" para pagar el precio, no se ha probado que lo haya hecho, y -continúa diciendo la sentencia- que cabe presumir que, si no lo hizo, "fue para colaborar en el propósito despatrimonializador, favoreciendo así que, ante la falta de pago del precio por PROINCOSA (sic, pero se refiere a EDIFOR, S.A.), esta no recuperara los bienes vendidos para hacer frente al pago de su deuda con los adquirentes de las viviendas". La presunción no está autorizada por indicios vehementes, ni por la causalidad ordinaria o normal de los acontecimientos, el id quod plerumque accidit, y la posibilidad de presunción no pasa de ahí, pero, sobre todo, se está describiendo una situación en la que el daño a los actores de este pleito se produce de modo indirecto, porque una sociedad compradora no paga el precio que adeuda y la vendedora no lo reclama, sin que se establezca una conexión entre el daño (frustración de cobro del crédito) y el comportamiento de la administradora de la sociedad compradora (y deudora del precio), y sin considerar que la insolvencia de la sociedad vendedora se ha podido producir por otras causas concurrentes.

Finalmente, se presentan en este caso graves problemas de imputación objetiva, confundidos con los problemas causales, toda vez que mal puede hablarse de causalidad en las omisiones, y de este modo poner a cargo de los administradores de la sociedad compradora el importe de los créditos que, entre muchos otros, adeuda la sociedad vendedora, sobre la base de que la compradora no pagó (y ni tan siquiera consta que la vendedora lo reclamara), sin establecer claramente la existencia de fraude y la colaboración en él de los implicados, parece contrario al criterio de imputación basado en el incremento del riesgo, dado que, con probabilidad cercana a la certeza, en vista de la situación de déficit patrimonial que constata la sentencia recurrida, la insolvencia de la sociedad se hubiera producido aun en el caso de que la sociedad compradora hubiera llevado a cabo el pago del precio. 
En consecuencia, se descarta el motivo décimo, que se apoya en la falta de prueba documental que ya ha sido anteriormente examinada, y descartada, mientras que, por otra parte, se formula para negar la inexistencia de una acción negligente, olvidando que puede consistir en una omisión; y se estiman los motivos octavo y noveno».

\section{$\mathrm{K}^{68}$. LA RESPONSABILIDAD DE LOS APODERADOS COMO ADMINISTRADORES DE HECHO.}

«4. D. Jose Antonio, ejercitó contra D. Ángel Daniel y D. Humberto acción de responsabilidad contra los administradores con fundamento en los arts. 69 de la Ley de Sociedades de Responsabilidad Limitada [LSRL] y 133 y 135 de la Ley de Sociedades Anónimas [LSA] fundada en una total falta de diligencia en la gestión de Frifer, S. L., entidad que carece de patrimonio, activos ni liquidez, con un volumen de negocios inexistente, en situación de insolvencia, sin que los administradores hayan procedido a la disolución. (....)

\section{QUINTO.} hecho.

A) La responsabilidad de los apoderados como administradores de

El art. 133 LSA se refiere como titulares de la responsabilidad que en él se establece a los «administradores» (o «miembros del órgano de administración»: art. 133.3 LSA). Esta cualidad solo la ostentan los nombrados como tales por la Junta General (art. 123 LSA), y, según la jurisprudencia, los administradores de hecho (expresamente a partir de la Ley 26/2003), es decir, quienes, sin ostentar formalmente el nombramiento de administrador y demás requisitos exigibles, ejercen la función como si estuviesen legitimados prescindiendo de tales formalidades.

La condición de administrador de hecho no abarca, en principio, a los apoderados (SSTS de 7 de junio de 1999 y 30 de julio de 2001), siempre que actúen regularmente por mandato de los administradores o como gestores de estos, pues la característica del administrador de hecho no es la realización material de determinadas funciones, sino la actuación en la condición de administrador sin observar las formalidades esenciales que la ley o los estatutos exigen para adquirir tal condición.

Cabe, sin embargo, la equiparación del apoderado o factor mercantil al administrador de hecho (STS de 26 de mayo de 1998, 7 de mayo de 2007 rec. 2225/2000) en los supuestos en que la prueba acredite tal condición en su actuación. Esto ocurre paradigmáticamente cuando se advierte un uso fraudulento de la facultad de apoderamiento en favor de quien realmente asume el control y gestión de la sociedad con ánimo de derivar el ejercicio de

${ }^{68}$ STS de 8 de febrero de 2008, Recurso 5168/2000 (ponente Xiol Ríos). 
acciones de responsabilidad hacia personas insolventes, designadas formalmente como administradores que delegan sus poderes, pero puede ocurrir también en otros supuestos de análoga naturaleza, como cuando frente al que se presenta como administrador formal sin funciones efectivas aparece un apoderado como verdadero, real y efectivo administrador social (STS de 23 de marzo de 2006, recurso 2643/1999).

B) Prueba de la condición de administradores de hecho.

La jurisprudencia declara constantemente que la casación no permite revisar la valoración de la prueba realizada por el tribunal de instancia, salvo casos de manifiesto error o arbitrariedad concretamente denunciada y demostrada (SSTS de 17 de enero de 2007 y 1 de febrero de 2007, entre otras muchas).

Esta doctrina es aplicable a la determinación de la existencia o no de actuación como administradores de hecho de la sociedad por parte de los demandados cuya responsabilidad se discute (SSTS de 7 de mayo de 2007, recurso 2225/2000 y STS 23 de marzo de 2006, recurso 2643/1999, ya citada).

En el caso examinado la sentencia recurrida declara que "a tenor del resultado de la prueba anteriormente analizada, esta permite confirmar sin ningún genero de duda que los demandados-apelados, Sres. Ángel Daniel y Humberto ostentaban realmente la condición de administradores de la mercantil Frifer, S. L."» (....).

\section{SÉPTIMO.}

A) La presunción de inocencia.

Con carácter auxiliar la parte recurrente invoca el principio de presunción de inocencia para salvar la responsabilidad de los administradores. Esta argumentación no puede ser aceptada, pues, como declara la STS 29 de septiembre de 2003, rec. 4105/1997, la presunción de inocencia, que proclama el artículo 24 de la Constitución Española tiene una aplicación relativa a las normas sancionadoras y represivas; no al Derecho civil, en que se plantean cuestiones de Derecho privado; y, en el ámbito estricto que estamos considerando, el carácter sancionador que a veces se atribuye a la responsabilidad de los administradores societarios solo puede admitirse en un sentido impropio (STS de 26 de septiembre de 2007, recurso 3528/2000).

Esto no es obstáculo para apreciar la ausencia de nexo de causalidad entre la conducta de los administradores de hecho y el daño causado, como se verá seguidamente.

B) La individualización de la acción ejercitada como acción individual de responsabilidad. Del escrito de demanda se deduce que la acción ejercitada es la acción individual de responsabilidad. (...).

C) La inexistencia de nexo de causalidad para apreciar responsabilidad individual de los administradores.

La acción individual de responsabilidad prevista en el artículo 135 LSA exige que se dé una conducta del administrador en el ejercicio de su cargo 
integrada por actos u omisiones negligentes productores de daños, según un razonable nexo causal (STS de 25 de abril de 2005). Este nexo de causalidad se vincula por la ley a un acto que genere una «lesión directa».

La negligencia que se atribuye a los administradores por la sentencia recurrida, se funda en que a) "no se ha procedido a la disolución y liquidación de la sociedad pese al incontrovertido hecho de que el estado patrimonial de la misma es la insolvencia" y b) los demandados han procedido "en nombre de Frifer, S. L., a la emisión y aceptación de unas letras de cambio en el año 1995, que resultaron impagadas, cuando ya había devenido imposible el previo cumplimiento de la obligación de pago derivado del documento de reconocimiento de deuda suscrito en el año 1993."

En esta relación de hechos no se aprecia una relación de causalidad entre el comportamiento de estos demandados, como administradores de hecho, y el daño ocasionado a la actora. En efecto:

a) La omisión del deber de promover la disolución de la sociedad no aparece, según los hechos que considera probados la sentencia recurrida, que fuera la causa directa de la insolvencia de esta o de la imposibilidad por parte de los acreedores de percibir su crédito por falta de una ordenada liquidación, pues únicamente se alude a la infracción del deber de promover la disolución de la sociedad, que se hallaba en situación de insolvencia.

b) La actuación que se describe de los apoderados aparece como tendente a facilitar el pago de la deuda dificultada por la situación económica de la sociedad y urgida a raíz del fallecimiento de su administrador. El dato de la emisión posterior de las letras en situación de insolvencia no resulta significativo, por cuanto ya se ha visto que responde a una imprecisión de la sentencia en la apreciación de los hechos probados que resulta objetivamente en la lectura del documento de reconocimiento de deuda de 1993, en el que ya se alude a las referidas letras. No aparece demostrado que el reconocimiento de la deuda y las condiciones pactadas para su pago fueran la causa de que se frustrase la realización del crédito, que en parte importante fue satisfecho con posterioridad a ese momento. En suma, la frustración del crédito del actor se ofrece como consecuencia de la situación de insolvencia en que vino a caer la sociedad y no se ha acreditado que esta obedeciera a la conducta de los administradores de hecho ni puede entenderse ligada causalmente, sin más, a la falta de disolución de la misma.

$\mathrm{L}^{69}$. Responsabilidad y no inscripción del cese en el Registro Mercantil. Falta de diligencia por la no inscripción.

«TERCERO. La cuestión sustancialmente planteada en el recurso de casación, que se desarrolla bajo distintos puntos de vista en los motivos que acaban de ser sintéticamente recogidos, es la relativa a si -supuesto que se

${ }^{69}$ STS 25 de septiembre de 2007, Recurso 4052/2000 (ponente XIOL RIUS). 
ha incumplido la obligación de inscribir la adaptación de los estatutos sociales a la nueva LSA y de promover la disolución de la sociedad por concurrir los presupuestos establecidos legalmente- existe responsabilidad personal y solidaria respecto de determinadas obligaciones sociales por parte de quienes aparecen en el Registro Mercantil como administradores en el momento en que aquellas fueron contraídas mediante la perfección de los correspondientes contratos en nombre de la sociedad, aun cuando el nombramiento de dichos administradores esté afectado por el transcurso del plazo de caducidad de cinco años establecido por el artículo 126 LSA y estos hayan efectivamente cesado con anterioridad.

Esta Sala tiene declarado en recientes resoluciones que la falta de inscripción del cese de los administradores en el Registro Mercantil no puede por sí misma ser determinante de la prolongación de su responsabilidad más allá de su cese efectivo, dado que este impide un ejercicio eficaz de las funciones de administración desde la fecha en que se produce, la inscripción carece de carácter constitutivo y la imposibilidad de oponer a terceros los efectos del cese del administrador cuando no ha sido inscrito (principio llamado a garantizar frente a terceros la efectividad de las obligaciones contraídas por los administradores aparentes en nombre de la sociedad) no es suficiente para la integración de los elementos determinantes de la existencia de responsabilidad de los mismos (SSTS de 23 de diciembre de 2002, recurso n. ${ }^{\circ} 1698 / 97,24$ de diciembre de 2002, recurso n. ${ }^{\circ} 1753 / 97$, 16 de julio de 2004, recurso n. ${ }^{\circ} 2566 / 98,28$ de mayo de 2005, recurso n. ${ }^{\circ} 4720 / 98,28$ de abril de 2006, recurso n. ${ }^{\circ} 3287 / 1999,26$ de mayo de 2006, recurso n. $.^{\circ} 3788 / 1999,7$ de febrero de 2007 , recurso n. ${ }^{\circ} 362 / 00,22$ de marzo de 2007, recurso n. ${ }^{\circ} 3447 / 2000$, y 4 de julio 2007, recurso n. ${ }^{\circ} 4503 / 2000$ ).

No cabe excluir, sin embargo, que la falta de inscripción pueda apreciarse como uno de los elementos determinantes de la existencia de responsabilidad en los casos en que, según el tipo de acción ejercitada, dicha ausencia se demuestre que obedece a la existencia de negligencia o dolo por parte de los administradores salientes, especialmente si la falta de inscripción del cese influye en la relación de confianza entre los terceros que contratan con la sociedad y esta.

Es menester, pues, determinar si en el caso examinado, teniendo en cuenta la expresada falta de inscripción, concurren los requisitos para la existencia de responsabilidad de los administradores por falta de adaptación de los estatutos sociales y por omisión del deber de promover la disolución de la sociedad, pues son estos los reproches que la sentencia recurrida dirige a su actuación para fundar su condena. La cuestión planteada no radica en si las referidas omisiones son imputables a los expresados codemandados como administradores, cuestión no puesta en duda en el presente recurso, sino en si puede exigírseles responsabilidad por el incumplimiento de unas obligaciones contraídas por la sociedad cuando aquellos ya habían cesado como administradores. 
Resulta obvio que en el momento en que se contrajeron las obligaciones a la efectividad de cuyo cumplimiento va dirigida la demanda los recurrentes habían cesado como administradores, no solamente porque su nombramiento había caducado de acuerdo con el artículo 126 LSA, sino también porque ni siquiera podía considerárseles como tales a los efectos de continuar provisionalmente la gestión de la sociedad en tanto se produjera la sustitución del órgano de administración, ya que cuando los contratos fueron perfeccionados se había celebrado ya una junta extraordinaria que había procedido al nombramiento de un nuevo administrador único.

La sentencia recurrida, no obstante estos hechos, mantiene la responsabilidad de los administradores cesantes por entender que habían abandonado sus obligaciones, al no lograr que el nuevo administrador inscribiese en el Registro Mercantil el nuevo nombramiento, que habían continuado como administradores de hecho, y que no se había destruido la apariencia registral mediante una nueva inscripción.

No podemos compartir esta valoración jurídica, susceptible de ser examinada en casación. En la junta extraordinaria en la que tuvo lugar su nombramiento se impuso al nuevo administrador la carga de proceder a la inscripción, por lo que era este el directamente obligado a solicitarla en nombre de la sociedad, no solo en virtud de lo establecido en el ordenamiento registral, sino también en virtud de lo expresamente previsto en el acta, por lo cual resulta indiferente que los requerimientos que algunos de los administradores cesantes dirigieron a aquel para exigir el cumplimiento de la obligación fueran posteriores a la perfección de los contratos determinantes de la responsabilidad exigida. Esta consideración resulta reforzada por el hecho de que en el momento en que se contrajeron o celebraron tales contratos por el nuevo administrador, el cual figuró como apoderado de la sociedad, podía deducirse de los datos obrantes en el Registro Mercantil que el nombramiento de los anteriores administradores había caducado, aunque los efectos de la caducidad no pueden considerarse equivalentes a los de la inscripción del cese y no pueden considerarse por sí mismos determinantes de la falta de responsabilidad. Finalmente, debe notarse que no se ha demostrado que la falta de inscripción haya resultado relevante en relación con el daño sufrido, dado que la contratación se realizó por el nuevo administrador, aunque apareciera como apoderado, y no consta que haya influido en la contratación la confianza suscitada por la creencia en la continuidad de los administradores cesantes.

Tampoco puede aceptarse que los administradores hubieran continuado a partir de 1993 actuando con conciencia de su cargo como administradores de hecho, pues basta con examinar los hechos que la sentencia expresamente declara probados, y que se resumen en el primer fundamento de esta sentencia, para comprobar que todos los que pudieran sustentar dicha presunción son anteriores a dicha fecha y que esta resulta destruida por el nuevo nombramiento, la actuación del nuevo administrador y la transmisión a este en su totalidad de las acciones sociales pertenecientes a aquellos. 
Finalmente, no puede considerarse que no se haya destruido la apariencia registral, pues, no teniendo la inscripción carácter constitutivo, el principio de legitimación registral está sometido a prueba en contrario, y, según la jurisprudencia que ya se ha invocado, la falta de inscripción del cese no comporta por sí misma la prolongación de la responsabilidad de los administradores por las obligaciones contraídas con posterioridad a su cese efectivo por cualquier causa».

\section{$\mathrm{M}^{70}$. EL TIEMPO (EL “MOMENTO") EN LA DETERMINACIÓN DE LA RESPONSABILI- DAD DE LOS ADMINISTRADORES.}

«Del desarrollo del motivo se desprende que el planteamiento del mismo se basa en que al encontrarnos ante un contrato de compraventa mercantil, en el que la esencial obligación de pago del comprador, de acuerdo con el artículo 339 del Código de Comercio, empieza en el momento en que las mercaderías vendidas son puestas a su disposición por el vendedor, carece de transcendencia la circunstancia de que la oferta y la aceptación pudieran concurrir en un momento anterior a la entrega y recepción del género, entendiendo, de este modo, la recurrente que el acto generador de responsabilidad del administrador se produjo con el nacimiento de la obligación de pago incumplida por la sociedad "Barcipeix, S.A.", y no en el momento en que se hicieron los pedidos y estos fueron aceptados.

El motivo debe ser desestimado. La Audiencia Provincial, en la sentencia impugnada, partiendo de los requisitos del artículo 135 de la Ley de Sociedades Anónimas consideró que el acto generador de responsabilidad para los administradores consistió en la asunción de nuevas obligaciones para la sociedad, cuando la situación económica impedía el cumplimiento de las mismas. La dicción del artículo 339 del Código de Comercio en ningún momento altera la regla básica de que el contrato de compraventa sea perfecto por el concurso de la oferta y la aceptación, y que genere obligaciones desde el mismo momento del consentimiento para ambas partes que pueden ser exigidas por estas, otra cosa es que, el comienzo de la obligación de pagar el precio se produzca, con la puesta de las mercaderías a disposición del comprador y con la satisfacción de este, lo que en nada afecta a la sustancial obligación que a las partes compete de cumplir el contrato, pues no se ha de confundir el momento de la perfección del contrato con el de su exigibilidad o su consumación.

Es más, en este caso concreto de los hechos declarados probados no se desprende actuación negligente alguna por parte de "Molí Vell, S.L.", la que, tras haber sido nombrada consejera delegada de "Barcipeix, S.A.", en junta general de 26 de enero de 1995, en la reunión del consejo de administración

${ }^{70}$ STS 5 de julio de 2007, Recurso 5513/2000 (ponente SIERRA GIL DE LA CUESTA). 
del día siguiente, 27 de enero de 1995, subordina el ejercicio de su cargo al resultado de la revisión de las cuentas y del informe de gestión que han de realizar los auditores, y, dimite en reunión del consejo de administración de 5 de marzo de 1995, confirmada en la junta de 6 de marzo de 1995, tras conocer los términos del informe de los auditores del día 24 de febrero de 1995, en el que se indica que el patrimonio de la sociedad y el fondo de maniobra eran de signo negativo, así como la incertidumbre sobre la capacidad de la sociedad de continuar con la actividad, debiendo señalar que es la fecha del cese y no la de su inscripción la que se debe tener en cuenta para poner fin al período que cabría de computar para exigir responsabilidad, como recientemente ha señalado la Sentencia de 10 de mayo de 2007, con cita de muchas anteriores».

\section{$\mathrm{N}^{71}$. RENUNCIA DEL ADMINISTRADOR Y EXTINCIÓN DE LA RESPONSABILIDAD.}

«Ante ello hay que decir que la cuestión planteada en el motivo ha sido abordada por la Sentencia de esta Sala de 28 de abril de 2006 que fija en la fecha de la renuncia por acta notarial el momento eficaz para poner fin al período que cabría de computar para exigir responsabilidad ya que "la renuncia impide una actuación eficaz desde la fecha en que se produce, que en este caso ha de tenerse por cierta, y que, dadas las específicas circunstancias del caso, ya destacadas, hace irrelevante que el momento de la inscripción se haya dilatado poco más de dos meses. La oponibilidad a terceros de los actos sujetos a inscripción y no inscritos, por otra parte, se presenta, en punto al cese de los administradores (art. 21.1 Ccom y 9 RRM), como un problema de eficacia respecto de la sociedad de actuaciones o gestiones realizadas por los administradores no inscritos o que permanecen inscritos después de su cese, cuestión distinta de la que aquí se está contemplando sobre todo cuando, como ocurre en el caso, la permanencia de la inscripción registral del administrador que ya ha cesado no ha sido determinante ni influyente en la relación entre la sociedad y el acreedor que reclama". Este criterio lo tiene reiterado esta Sala en numerosas Sentencias -de 10 de mayo de 1999, de 23 de diciembre de 2002, 24 de diciembre de 2002, de 16 de julio de 2004, de 28 de mayo de 2005, y muy recientemente en las Sentencias de 7 de febrero de 2007, y 22 de marzo de 2007-, en las que se declara que las inscripciones registrales de los acuerdos de cese no tienen carácter constitutivo, al no imponerlo así precepto alguno, correspondiendo, en su caso, el deber de inscribir a los nuevos administradores, sin que ninguna responsabilidad por falta de inscripción pudiera exigirse a los cesados».

${ }^{71}$ STS de 10 de mayo de 2007, Recurso 3032/2000 (ponente SIERRA GIL DE LA CUESTA). 


\section{Conclusiones}

Primera. El Tribunal Supremo no ha creado un cuerpo de doctrina que contenga unos elementos estructurantes generales, a modo de principios secundarios derivados de los principios primarios en que consisten los deberes fiduciarios de diligencia, fidelidad y lealtad. No hay en la jurisprudencia descripciones que contengan los elementos permanentes caracterizadores de esos deberes, es decir, que permitan realizar un tránsito gradual y seguro desde lo más abstracto (los principios primarios) a lo más concreto (los hechos y circunstancias particulares del «caso»). Así, se constata la existencia del «salto» en el argumento o discurso judicial. No se sigue, por lo tanto, un modelo semejante al americano, que permite -hasta cierto puntoahormar con más certidumbre los hechos en la norma a través de una aproximación de «doble fase».

Segunda. Las preguntas que suscita inmediatamente la anterior constatación son las dos siguientes: ¿por qué es así?; y, segunda, ¿es ello bueno o malo?

Para la primera cuestión se ofrecen varias respuestas: en los sistemas anglosajones el papel de los jueces siempre ha sido activo en la configuración del Derecho, precisamente por razón del déficit regulador, lo que se ha traducido en que el juez sea una especie de juez-legislador; la actitud de la judicatura americana resulta en general más vitalista, más realista y más activista y, por el contrario, la cultura jurídica y los hábitos judiciales del Viejo Continente han resultado en una jurisdicción menos «creativa» y original, como corresponde a un espacio más acotado atribuido a su intervención; el juez anglosajón presta más atención a la realidad sobre la que se proyecta la norma (su creación del Derecho parece ir en el sentido «de la realidad a la norma»), mientras el juez continental teje su argumento «desde la norma hasta la realidad», lo que da como resultado planteamientos más formalistas, menos atentos al sustrato económico, al hecho empresarial, y societario y a la experiencia de las funciones, actividades, y grado de exigencia en el desempeño del cargo de administrador. Todo ello tiene, sin duda, que ver con la diferente cultura jurídica de partida que ya se apuntaba, pero, como manifestación de ella, con el «proceso de producción de jueces» y las diferentes condiciones que se exigen para acceder a la judicatura.

A todo lo anterior ha de añadirse que las sentencias que hemos seleccionado lo son del Tribunal Supremo, que siempre las dicta en grado de casación, y es bien conocido que este recurso extraordinario resulta refractario al análisis de los hechos, añadiendo la especial técnica casacional, y el formalismo con que adicionalmente la aplica el Alto Tribunal, una razón adicional para no entrar en el análisis de aspectos fáctico-materiales, cuya consideración podría dar ocasión para aprestar un cuerpo de doctrina de principios secundarios, a modo de haces de los deberes generales o fiduciarios.

En cuanto a la segunda cuestión, no se puede afirmar categóricamente la superioridad del sistema angloamericano sobre el nuestro. El primero tiene 
la aparente ventaja de la certidumbre o previsibilidad del fallo judicial, pues la indefinición del principio general abstracto y evanescente se «domestica» a través de los principios secundarios que de él extrae la jurisprudencia. No obstante, esta ventaja resulta en no pocas ocasiones contradicha por la ductilidad con que los tribunales aplican esos principios secundarios, dando lugar a respuestas inesperadas o sorprendentes, abiertamente contradictorias con el significado que razonablemente cabía esperar de esos principios secundarios en que se «corporeiza» el espíritu del principio general. La ausencia de ese «paso intermedio» constituida por los principios secundarios de creación jurisprudencial, en cambio, deja a nuestros jueces manos libres para hacer la «justicia del caso», dándoles un apreciable margen de maniobra, que resulta en la posibilidad de no aplicar elegantemente el criterio declarado en anterior sentencia por no ser los hechos nuevos «exactamente iguales».

Tercera. Son muchos los casos que se suscitan sobre responsabilidad de los administradores sociales, y también abundantes los en que el Tribunal Supremo ha sido llamado a pronunciarse. Hay procesos con un objeto muy recurrente, como hemos podido comprobar: la responsabilidad de los administradores por no promover la disolución de la sociedad cuando concurre causa legal para ello (art. 262.5 L.S.A.), responsabilidad solidaria y que califican los tribunales de objetiva o casi objetiva, lo mismo que la contemplada en la Disposición Transitoria 3. ${ }^{\mathrm{a}} .3$, aunque ya sea solo una curiosidad histórica, para el caso de no adaptación de los estatutos sociales a la «nueva» ley antes del 30 de junio de 1992; la diferencia de la anterior responsabilidad objetiva con la que se hace valer a través de la acción individual de responsabilidad del art. 135 L.S.A, de carácter subjetivo, como basada en el presupuesto de la culpabilidad del administrador; el plazo de prescripción de la acción de responsabilidad individual; la determinación del dies a quo o término inicial para el cómputo de dicho plazo; etc. Pero son todas ellas cuestiones que, sin perjuicio de su relevancia práctica, tienen una dimensión netamente formalista. No nos dice casi nada el Tribunal sobre en qué consiste la diligencia (a lo más, que hay que desplegarla en la actividad de supervisión que compete a los administradores; que en la omisión o dolce far niente hay incumplimiento del deber de diligencia; que la diligencia obliga al seguimiento de las cuentas de la sociedad), y aún menos menos sobre la lealtad y la fidelidad. Tal vez la ley de transparencia esté todavía muy próxima en el tiempo y no ha dado oportunidad al Tribunal Supremo, habida cuenta de la duración media de las tres instancias, para expresar su criterio sobre el significado de la familia de los artículos 127 de la L.S.A. Es igualmente desértico el paisaje relativo a las causas de atenuación o exoneración de la responsabilidad de los administradores. Fuera de la afirmación negativa de que al administrador no aprovecha el derecho fundamental a la presunción de inocencia (art. 24 C.E.), porque cuando se ejercitan frente a él acciones de responsabilidad nos movemos en el ámbito de las responsabilidades civiles y no 
penales o administrativas (único para el que está pensado aquella presunción), no encontramos prácticamente nada más.

Llama la atención también la poca frecuencia con que el Tribunal Supremo se enfrenta a demandas de responsabilidad social. Sólo hemos identificado un par de casos entre las muchas decenas de sentencias que hemos examinado. ¿Qué sucede? Pudiera ser tan elevado el coste económico y psicológico de emprender tales acciones, bien por los socios, bien por los acreedores, que el efecto disuasorio acabara prevaleciendo; o que la disuasión se debiera a otras razones (la fuerza intimidatorio de la propia compañía, o las «recompensas» que esta ofreciera a cambio de la indulgencia del socio dispuesto a embarcarse en un tal proceso). Precisamente este tipo de demandas de responsabilidad social son las que han dado lugar a un cuerpo de doctrina judicial más elaborado en Estados Unidos, como ya sabemos por la primera parte de este trabajo.

No obstante, si no resultara frívolo, me atrevería a pronosticar que en los próximos cinco años se va a producir entre nosotros un enriquecimiento de la doctrina jurisprudencial sobre la responsabilidad de los administradores, al que habrá que prestar estrecha atención. ¿Por qué? No se les escapan a ustedes las razones, que resultan muy obvias: primero, porque la actual situación de crisis va a generar (está generando ya) situaciones de enfrentamiento y tensión socios-sociedad-administradores mucho más intensos que en época anterior; segundo, porque al «hecho» (a «ese» hecho) le corresponde la nueva realidad legislativa -recordemos, los «127» introducidos en la L.S.A. por la «ley de transparencia» de 2003-, que están ya completando el largo plazo de vacatio iurisprudentae, decalaje o retardo, que es necesario completar hasta que, agotadas las instancias ordinarias, lleguen los «casos» al Alto Tribunal.

Así que he de terminar este segundo capítulo como el primero: con un «fin» que es provisional, porque en realidad se trata de un continuará..., pero ya dentro de los cinco años anunciados. 